\title{
AVALIAÇÃO LONGITUDINAL, CLÍNICA E RADIOGRÁFICA, DO PROCESSO DE REPARO DOS TECIDOS PERIODONTAIS MARGINAIS APÓS CIRURGIA RESSECTIVA DE AUMENTO DE COROA
}

Marly Kimie Sonohara Gonzalez

Tese apresentada à Faculdade de Odontologia de Bauru, da Universidade de São Paulo, como parte dos requisitos para obtenção do título de Doutor em Odontologia, na área de Reabilitação Oral

(Edição Revisada)

Bauru

2006 


\section{AVALIAÇÃO LONGITUDINAL, CLÍNICA E RADIOGRÁFICA, DO PROCESSO DE REPARO DOS TECIDOS PERIODONTAIS MARGINAIS APÓS CIRURGIA RESSECTIVA DE AUMENTO DE COROA}

Marly Kimie Sonohara Gonzalez

Tese apresentada à Faculdade de Odontologia de Bauru, da Universidade de São Paulo, como parte dos requisitos para obtenção do título de Doutor em Odontologia, na área de Reabilitação Oral

(Edição Revisada)

Orientador: Prof. Dr. Sebastião Luiz Aguiar Greghi

Bauru

2006 
Gonzalez, Marly Kimie Sonohara

G589a Avaliação longitudinal, clínica e radiográfica, do processo de reparo dos tecidos periodontais marginais após cirurgia ressectiva de aumento de coroa / Marly Kimie Sonohara Gonzalez. - Bauru, 2006. 129p. : il.; $30 \mathrm{~cm}$.

Tese (Doutorado) - Faculdade de Odontologia de Bauru, USP

Orientador: Prof. Dr. Sebastião Luiz Aguiar Greghi

Autorizo, exclusivamente para fins acadêmicos e científicos, a reprodução total ou parcial desta tese, por processos fotocopiadores e outros meios eletrônicos.

Assinatura:

Data: 30 de agosto de 2006.

Comitê de Ética da FOB

Protocolo n ${ }^{\circ} 36 / 2004$

Data: 31 de março de 2004 


\section{Marly Kimie Sonohara Gonzalez}

22 de fevereiro de 1969

$1986-1989$

1990

$1991-1992$

1992

1994-1997

2003-2006
Nascimento - Astorga-PR

Curso de Graduação em Odontologia pela Faculdade de Odontologia de Bauru - USP.

Estágio em Periodontia no Hospital de Pesquisa e Reabilitação de Lesões Lábio Palatais - USP.

Residência - Especialização em Periodontia no Hospital de Pesquisa e Reabilitação de Lesões Lábio Palatais - USP.

Professora do Departamento de Odontologia da Universidade Estadual de Maringá - UEM.

Curso de Mestrado em Periodontia pela Faculdade de Odontologia de Bauru - USP.

Curso de Doutorado em Reabilitação Oral pela Faculdade de Odontologia de Bauru - USP. 


\section{Dedicatória}

A todos os Mestres que contribuíram para a minha forma ção pessoal e profissional, em especial a:

ACCÁCIO LINS DO VALLE

ADRIANA C. PASSANEZI SANT'ANA

ALBERTO CONSOLARO

ALCEU BERBET

ALCEU SÉRGIO TRINDADE JR.

ANA LÚCIA ÁLVARES CAPELOZZA

ANA MARIA L. V. ZOGHEIB (in memorian)

ANA PAULA CAMPANELLI

ANTÔNIO CARLOS MARCONI STIPP

ANTÔNIO GABRIEL ATTA (in memorian)

ANTÔNIO LÁZARO V. MARQUES

ANTÔNIO RICCI

AQUIRA ISHIKIRIAMA

ARNALDO PINZAN

ARSÊNIO SALES PERES

ASTRID ZARAMELLA VONO

AYMAR PAVARINI

BERNARDO GONZALEZ VONO

CARLOS DOS REIS P. DE ARAÚJ O

CARLOS EDUARDO FRANCISCHONE

CARLOS EDUARDO PINHEIRO
CARLOS FERREIRA DOS SANTOS

CÉSAR B. RODRIGUES (in memorian)

CLÓVIS MARZOLA

CLÓVIS MONTEIRO BRAMANTE

DAGOBERTO SOTTOVIA FILHO

DÉCIO RODRIGUES MARTINS

DENISE TOSTES OLIVEIRA

DEOCLÉCIO NAHÁS (in memorian)

EDUARDO BATISTA FRANCO

EDUARDO SANT'ANA

EID MUNIZ ASCKAR

ERNESTO PILOTTO G. DE MEDEIROS

EULÁZIO MIKIO TAGA

EULOIR PASSANEZI

EYMAR SAMPAIO LOPES

FLÁVIO AUGUSTO C. DE FARIA

GÉRSON BONFANTE

GÉRSON FRANCISCO DE ASSIS

GUILHERME DOS REIS P. JANSON

HALIM NAGEM FILHO

HERMÓGENES DE FREITAS (in memorian) 
INGE ELLY KIEMLE TRINDADE

IVALDO GOMES DE MORAES

IZABEL REGINA F.R. DE BULLEN

JANETE DE AGUIRRE BERVIQUE

JESUS CARLOS ANDREO

J OÃO A. CALDAS NAVARRO (in memorian)

J OÃO LOPES TOLEDO FILHO

J OÃO LÚCIO CORADAZZI

JOSÉ CARLOS PEREIRA

JOSÉ CHIODI NETO (in memorian)

JOSÉ EDUARDO DE O. LIMA

JOSÉ FERNANDO C. HENRIQUES

JOSÉ HENRIQUE RUBO

JOSÉ HUMBERTO DAMANTE

JOSÉ MAURO GRANJEIRO

JOSÉ MONDELLI

JOSÉ ROBERTO DE M. BASTOS

JOSÉ ROBERTO PEREIRA LAURIS

JOSÉ SIMÕES BARROSO (in memorian)

JOSÉ VALDES CONTI (in memorian)

JÚLIO DE ARAÚJO GURGEL

LUCIMAR FALAVINHA VIEIRA

LUIS ANTÔNIO DE A. TAVEIRA

LUIZ CASATI ALVARES

LUIZ EDUARDO M. CHINELLATO

LUIZ FERNANDO PEGORARO

MARCOS ROBERTO DE FREITAS

MARIA APARECIDA DE A. M. MACHADO

MARIA FIDELA DE L. NAVARRO

MARIA FRANCISCA T. BORRO BIJELLA

MARIA LÚCIA RUBO REZENDE

MARIA TERESA ATTA

MARÍLIA AFONSO RABELO BUZALAF

MÁRIO HONORATO S. E SOUZA JÚNIOR

MILTON CARLOS G. SALVADOR

NEVALDO ALLE
NEY MORAES (in memorian)

NILCE EMY TOMITA

NORBERTI BERNARDINELI

ODILA PEREIRA DA SILVA ROSA

OLINDA TÁRZIA

ORIVALDO TAVANO

OSNY FERREIRA

OSNY FERREIRA JÚNIOR

PAULO AFONSO S. FRANCISCONI

PAULO AMARANTE DE ARAÚJO

PAULO CÉSAR RODRIGUES CONTI

PAULO FERRAZ DA COSTA (in memorian)

PAULO MARTINS FERREIRA

PAULO SÉRGIO PERRI DE CARVALHO

RAFAEL FRANCISCO LIA MONDELLI

RAUL NEGRÃO FLEURY

REGINA STELA STILAC ROCHA

REINALDO MAZZOTTINI

RENATO DE FREITAS

RENATO RODRIGUES DE ALMEIDA

RICARDO MARINS DE CARVALHO

ROBERTO BRANDÃO GARCIA

ROBERTO LOUREIRO MARINGONI

RUBENS FLORINO PANDOLFI

RUMIO TAGA

RUY CÉSAR CAMARGO ABDO

SALETE MOURA B. DA SILVA

SEBASTIÃO LUIZ AGUIAR GREGHI

SÉRGIO A. CATANZARO GUIMARÃES

SÉRGIO APARECIDO TORRE

VALÉRCIO BONACHELA

VANESSA SOARES LARA

VINÍCIUS CARVALHO PORTO

VITORIANO TRUVIJO BIJELLA

WALDYR ANTÔNIO JANSON

WELLINGTON CARDOSO BONACHELA 


\section{Agradecimentos Especiais}

Agradeço sincera e profundamente:

Ao Grande Deus Pai pelo seu grandioso amor repleto de Luz e pelas inúmeras bênçãose proteções recebidas

Aos Grão-Mestres Kotama Okada, Keishu Okada e Koya Okada pelos maravilhosos ensina mentos que me despertaram para o a mor altruísta

Aos meus antepassados pelos esforços e dedicações realizados para que eu pudesse estar presente neste mundo físic o

A meus pa is Hiroshi e Olga pela maravilhosa concessão do infinito amor, contribuindo para o meu crescimento e fortalecimento espinitual

Ao meu marido Carlos, por compartilhar seus sentimentos mais profundose porme fazerfeliz

A meus imãos Marta, Yudi, Shigueo e Meire, cunhado Gilberto e sobrinhos Sayuri e Yukio, pela grande oportunidade do nosso reencontro e da beleza de nossa convivência 
Ao meu Orientador

\section{Prof. Dr. Sebastião Luiz Aguiar Greghi}

Agradeço, sincera e profundamente, pela sua paciência e compreensão, pela concessão de suas palavras e orientações, e pela permissão de a prender e vivenciar a sua sabedoria e humilda de de sentimentos, que foram fundamentais para minha formação profissional.

MUITISSIMO OBRIGADA! 


\section{AGRADEÇO}

Aos Professores do Departamento de Prótese e Disciplina de Periodontia, por me concederem a oportunidade de vivenciar a integração dos conhecimentos repletos de sabedoria

A todos os pacientes, pela confiança e persistência, que contribuíram para a concretização desta pesquisa

A Ana Cláudia Pereira Mattar, Ana Lúcia Pompéia Fraga de Almeida, Ana Raquel Benetti, Camila Ferrari Soares, Cássia Fischer Rubira, Clanissa Ribeiro Fonseca, Cleusa Gonçalves Leite, Daniela Eleutério Diniz, Deborah Andrea Riêra Blasca, Edilaine Lucio Rodrigues Torrecilha, Edna Zaupa Nebo, Eduardo Figueira, Eduardo Covolan, Heitor Honório, Ivânia Komatsu da Costa Amuda, Ka lizia Marcela Okuda, Leucy Barbosa de Oliveira, LuÍs Eduardo Butignon, Luiz Gustavo Bastos, Marcos Antônio de Godoy, Neide Leandro, Romão Adalberto de Souza Mansano, Thiago Amadei Pegoraro e Valéria Trindade Ferraz, pela valiosa ajuda, compreensão e incentivo para rea lização deste trabalho

Ao Prof. Dr. José Mondelli, por confiar em mim seus preciosos ensinamentos de vida

Ao Prof. Dr. J osé Roberto Pereira Lauris, pela orientação na análise estatística

À Família Akamine, Cameiro, Costa Amuda, Damasceno, Gonzalez, Guimarães-Tavares, Mondelli, Nahás, Okuda, da Silva, Siraichi, Sonohara e Terada, por me receberem e por me transmitirem exemplos de unidade

A Luciana Shiguemi Akamine e Meire Yurie Sonohara, pela inestimável ajuda, apoio e compreensão nas atividades profissionais durante minha ausência no consultório, ensinando-me a praticar a humildade de sentimentos

A Ana Lúcia de Almeida, Antônio Ricardo Duarte, Eduardo Ayub, Jefferson Pereira, Leylha Maria Oliveira, Margareth Nunes, Luiz Gustavo Bastos, Marina Fracasso, Marinele de Campos, Osvaldo Kaizer, Paulo Yamaguti, Paulo Rossetti, Rafael dos Santos Silva, Renato Ferreira da Silva e Tatiany de Mendonça Neto, pela convivência ao longo do curso

Aos funcionários de todos os Setores e Departamentos da FOB, pela paciência e colaboração para o meu aprendizado diánio na etapa de Graduação e Pós-graduação

A Strategos - Engenharia, Informática e Consultoria Ltda, pelo especial apoio concedido durante todo período do curso

A Empresa Comercial Maripa Ltda, pela concessão dos produtos Bitufo ${ }^{\circledR}$ 
À Comissão de Pós-graduação da Faculdade de Odontologia de Bauru

À Universidade Estadual de Maringá

Ao Departamento de Odontologia da Universidade Esta dual de Maringá

Aos Professores Mário Taba Júnior, Mauńcio Guimarães Araújo e Roberto Masayuki Hayacibara

E a todos que até o presente momento contribuíram para o meu aprimoramento espintual, profissional e pessoal

MUITO OBRIGADA! 


\section{SUMÁRIO}

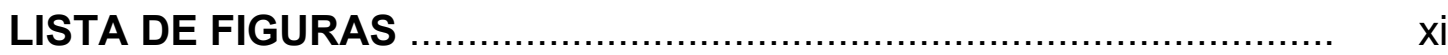

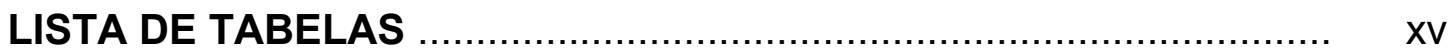

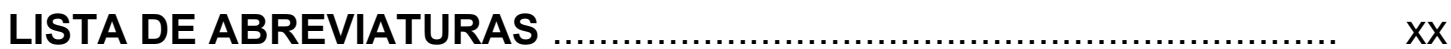

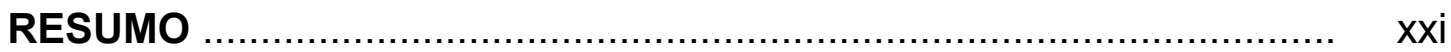

1 INTRODUÇÃO ..................................................................... 1

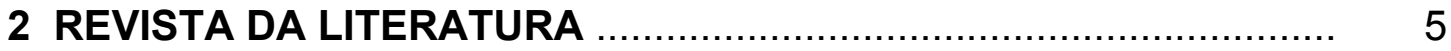

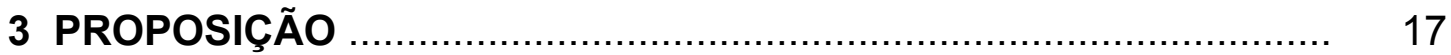

4 MATERIAL E MÉTODOS ...................................................... 21

4.1 Seleção da amostra .......................................................... 23

4.2 Avaliação inicial da amostra ................................................. 24

4.3 Padronização da amostra .................................................... 25

4.4 Avaliação clínica ................................................................ 26

4.5 Avaliação radiográfica ......................................................... 39

4.6 Técnica cirúrgica ............................................................ 41

4.7 Controle pós-operatório ...................................................... 42

4.8 Reavaliações ................................................................. 44

4.9 Análise estatística ............................................................ 44

5 RESULTADOS …..................................................................... 45

5.1 Avaliação clínica ............................................................... 49

5.2 Avaliação radiográfica .................................................. 60

6 DISCUSSÃO ..................................................................... 63

6.1 Avaliação clínica ................................................................... 65

6.2 Avaliação radiográfica .................................................... 104

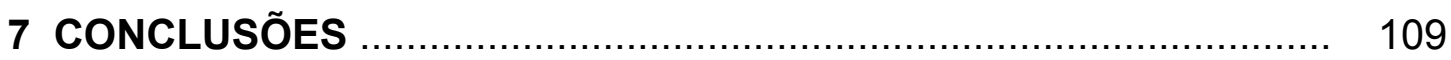

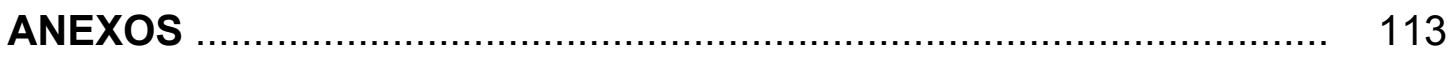

REFERÊNCIAS BIBLIOGRÁFICAS ......................................... 117

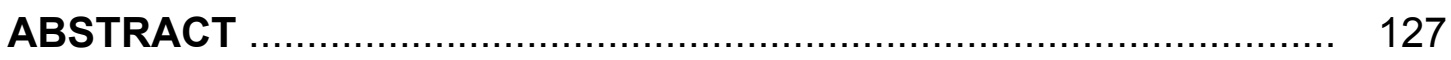




\section{LISTA DE FIGURAS}

FIGURA 4.1 - Avaliação clínica. (A) Placa oclusal (guia) confeccionada em resina acrílica com pontos ou sulcos de referência fixos, (B) para obtenção de medidas clínicas em 6 sítios ( $\bullet$ ): quatro sítios no pré-molar a ser tratado, centro das faces mesial $(M)$, vestibular $(V)$, lingual $(L)$ e distal $(D)$; e dois sítios nos dentes adjacentes, um no centro da face distal do dente localizado à mesial (Da) e outro, no centro da face mesial do dente localizado à distal (Ma) do prémolar a ser tratado. (C) Localização da sonda periodontal milimetrada no sulco de referência vestibular, com a superfície oclusal plana da placa servindo como stop para cursor endodôntico. (D) Medida clínica do nível de inserção relativo e (E) da junção mucogengival vestibular, após aplicação de solução de Schiller. (F) A mensuração da medida obtida com sonda milimetrada e cursor foi realizada por meio do paquímetro digital Starrett ${ }^{\circledR}$

FIGURA 4.2 - Desenho esquemático das medidas clínicas realizadas na fase pré-cirúrgica, cirúrgica e de controle (1 a 12 meses): a, a' e a" - distância do término cervical (TC) em relação à margem gengival (MG); b e b' - distância entre término cervical e crista óssea; c, c' e c" - tecido gengival supra-ósseo; d e d' - aumento de coroa clínica aparente obtido; e - ressecção óssea; f migração da margem gengival. (NO - nível ósseo; $\mathrm{NO}_{\text {pré }}$ - nível ósseo préosteotomia; $\mathrm{NO}_{\text {pós }}$ - nível ósseo pós-osteotomia; $\mathrm{MG}_{\text {pré }}$ - margem gengival précirúrgica; $\mathrm{MG}_{\text {pós-sutura }}$ - margem do retalho após sutura; $\mathrm{MG}_{1-12 \text { meses }}$ - margem gengival após 1-12 meses da cirurgia) 31

FIGURA 4.3 - (A) Medida da espessura gengival no centro da face vestibular do segundo pré-molar $(\bullet)$ com agulha anestésica e cursor endodôntico foi obtida no nível da profundidade do sulco gengival. (B) A mensuração dessa medida foi realizada com paquímetro digital Starrett $₫$ 33 
FIGURA 4.4 - Medida da menor distância inter-radicular entre pré-molar e dente adjacente com paquímetro digital Starrett $^{\circledR}$ em molde de silicona de condensação Optosil ${ }^{\circledR}$

FIGURA 4.5 - Numa vista oclusal, observa-se coaptação das margens dos retalhos vestibular e lingual no sítio mesial e exposição óssea no sítio distal do segundo pré-molar 33

FIGURA 4.6 - Ilustração da forma da papila gengival em modelo de gesso: numa vista proximal da papila, nota-se sua forma côncava (A), plana (B) e convexa (C) 35

FIGURA 4.7 - "Dobra" na papila gengival: numa vista vestibular da área do primeiro pré-molar, a papila gengival mesial apresenta-se com contorno biselado, enquanto a papila distal, com presença de "dobra" (seta) (A). No modelo de gesso, a "dobra" pode ser analisada no sentido vestíbulo-lingual como um achatamento da porção vestibular da papila gengival (B) 35

FIGURA 4.8 - Aspecto da papila gengival: numa vista oclusal da região do segundo pré-molar, a papila distal apresenta-se com aspecto liso e brilhante (A) e após 12meses, observa-se com aspecto casca de laranja (stippling) (B).... 35

FIGURA 4.9 - Avaliação radiográfica. Posicionador radiográfico interproximal duplicado em resina acrílica incolor, com registro oclusal dos dentes em resina Duralay $(\mathbf{A})$, foi acoplado à haste indicadora e anel localizador para tomada radiográfica interproximal padronizada $(\mathbf{B})$ 37 
FIGURA 4.10 - Desenho esquemático da técnica cirúrgica de aumento de coroa. Término cervical do preparo para coroa total do $1^{\circ}$ pré-molar localizado subgengival (a), numa distância $<2 \mathrm{~mm}$ até crista óssea alveolar (b). Rebatimento do retalho total vestibular e lingual, a partir de incisão intrasulcular e/ou em bisel interno, permite acesso à crista óssea e confirmação da invasão do espaço da distância biológica (c). Realização de osteotomia/osteoplastia para obter uma distância mínima de $3 \mathrm{~mm}$ entre término cervical e crista alveolar, com reprodução do arco côncavo num nível mais apical (d). Retalhos imobilizados por meio de suturas (e) e posicionados coronal à crista óssea e apical ao término cervical (f)

FIGURA 5.1 - Representação gráfica dos valores médios das medidas de margem gengival nos sítios mesial, vestibular, lingual e distal na fase cirúrgica e de controle pós-operatório de 1, 2, 3, 4, 5, 6 e 12 meses, em milímetros 54

FIGURA 5.2 - Vista vestibular do segundo pré-molar imediatamente após sutura do retalho total coronal à crista óssea $(\mathbf{A})$ Durante a fase de controle pós-operatório de 1 mês (B), 2 meses (C), 3 meses (D), 4 meses (E), 5 meses $(\mathbf{F}), 6$ meses $(\mathbf{G})$ e 12 meses $(\mathbf{H})$, houve migração da margem gengival para apical no sítio vestibular e para coronal nos sítios mesial e distal, a partir da margem do retalho pós-sutura. A papila gengival sem "dobra" foi observada após 3 meses na mesial e aos 12 meses na distal 57

FIGURA 5.3 - Radiografia interproximal do segundo pré-molar inferior esquerdo antes da cirugia (A), após osteotomia (B) e aos 2 meses (C), 3 meses (D), 6 meses (E) e 12 meses (F) após cirurgia. A presença da lâmina dura intacta foi observada na crista óssea mesial aos 6 meses e na crista óssea distal, aos 12 meses 
FIGURA 6.1 - Desenho esquemático das medidas clínicas. A medida do tecido gengival supra-ósseo (TGS ), desde a margem gengival (MG) até nível ósseo (NO), é obtida previamente à cirurgia . Após definição do término cervical (TC), como ponto de referência fixo, e ressecção óssea, a medida do TC até NO (distância mínima - DM) é obtida antes da sutura do retalho 88

FIGURA 6.2 - Desenho esquemático da previsão da margem gengival estável (MG estável) em relação ao término cervical (TC). Esta previsão baseia-se na reformação da medida pré-cirúrgica do tecido gengival supra-ósseo (TGS sobre a superfície dentária coronalmente (seta larga) à margem do retalho suturado (MG pós-sutura). Um valor negativo (A) para Posição Estável da Margem (PEM) representaria localização final da MG apical ao término cervical (TC), e um valor positivo (B), localização da MG coronal ao TC. 91

FIGURA 6.3 - Desenho esquemático da delimitação da nova e futura margem gengival com uma incisão em bisel interno na face vestibular do primeiro prémolar (linha tracejada), correspondendo ao aumento de coroa clínica aparente desejado 91

FIGURA 6.4 - Desenho esquemático da definição da futura margem gengival durante a cirurgia. Uma incisão em bisel interno determina a quantidade de aumento de coroa clínica aparente desejada. O restabelecimento seta da

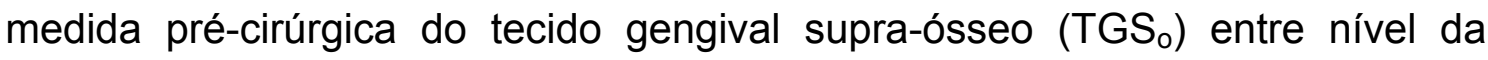
incisão e o nível ósseo (NO) determina a quantidade de ressecção óssea (RO) a ser realizada. Após reposicionamento e sutura do retalho (MG pós-sutura) coronal ao NO pós-osteotomia, a previsão estável da margem (PEM) pode ser monitorada periodicamente em relação ao término cervical (TC). (MG margem gengival)

FIGURA 6.5 - Radiograficamente, a delimitação do espaço interdentário assemelha-se a uma "casa" (GONZALEZ et al.*) 94 


\section{LISTA DE TABELAS}

TABELA 4.1 - Seqüência dos parâmetros clínicos e das radiografias (RX) na fase pré-cirúrgica, cirúrgica (pré-osteotomia, pós-osteotomia e pós-sutura) e de controle pós-operatório (1, 2, 3, 4, 5, 6 e 12 meses) 37

TABELA 5.1 - Distribuição do número de dentes (n) pré-molares 14, 15, 24, 25 , 34, 35, 44 e 45 de acordo com a causa da indicação cirúrgica (coroa clínica curta ou invasão do espaço da distância biológica pela cárie ou fratura dentária ou término cervical pré-existente) e o tipo de preparo dentário (coroa protética ou restauração)

TABELA 5.2 - Distribuição do número de sítios (n) mesial, vestibular, lingual e distal com invasão do espaço da distância biológica (distância $\leq 2,0 \mathrm{~mm}$ entre término cervical e crista óssea alveolar) 48

TABELA 5.3 - Distribuição dos sítios mesial, vestibular, lingual e distal com placa bacteriana na fase pré-cirúrgica e de controle pós-operatório de 1, 2, 3, 4, 5,6 e 12 meses, em porcentagem

TABELA 5.4 - Distribuição dos sítios distal adjacente, mesial, vestibular, lingual, distal e mesial adjacente com sangramento gengival na fase précirúrgica e de controle pós-operatório de 2, 3, 4, 5, 6 e 12 meses, em porcentagem 49

TABELA 5.5 - Valores médios e desvios padrão das medidas de profundidade de sondagem nos sítios distal adjacente, mesial, vestibular, lingual, distal e mesial adjacente na fase pré-cirúrgica e de controle pós-operatório de 2, 3, 4, 5 , 6 e 12 meses, em milímetros, e resultados da ANOVA e Teste de Tukey ...... 50 
TABELA 5.6 - Valores médios e desvios padrão das medidas de nível de inserção relativo nos sítios distal adjacente, mesial, vestibular, lingual, distal e mesial adjacente na fase pré-cirúrgica e de controle pós-operatório de 2, 3, 4, 5 , 6 e 12 meses, em milímetros, e resultados da ANOVA e Teste de Tukey ..... 50

TABELA 5.7 - Valores médios e desvios padrão das medidas da distância entre término cervical e crista óssea alveolar nos sítios mesial, vestibular, lingual e distal na fase cirúrgica pré e pós-osteotomia, em milímetros 51

TABELA 5.8 - Distribuição do número de sítios (n) e sua porcentagem (\%) de acordo com a quantidade de ressecção óssea realizada ao redor dos dentes pré-molares 51

TABELA 5.9 - Valores médios e desvios padrão das medidas de ressecção óssea (RO) realizada nos sítios distal adjacente, mesial, vestibular, lingual, distal e mesial adjacente durante a fase cirúrgica, em milímetros 51

TABELA 5.10 - Valores médios e desvios padrão das medidas de distância inter-radicular (DI) mesial e distal, pré e pós-osteotomia, em milímetros 52

TABELA 5.11 - Distribuição do número de sítios proximais (n) e sua porcentagem (\%) de acordo com presença e ausência de exposição óssea póssutura do retalho 52

TABELA 5.12 - Valores médios e desvios padrão das medidas de junção mucogengival (JMG) e de mucosa ceratinizada (MC) vestibular na fase précirúrgica, cirúrgica e de controle pós-operatório de 1, 2, 3, 4, 5, 6 e 12 meses, em milímetros, e resultados da ANOVA e Teste de Tukey 52 
TABELA 5.13 - Valores médios e desvios padrão da localização do término cervical em relação à margem gengival nos sítios mesial, vestibular, lingual e distal na fase pré-cirúrgica, cirúrgica e de controle pós-operatório de 1, 2, 3, 4, 5, 6 e 12 meses, em milímetros

TABELA 5.14 - Valores médios e desvios padrão das medidas de tecido gengival supra-ósseo nos sítios mesial, vestibular, lingual e distal na fase précirúrgica, cirúrgica e de controle pós-operatório de 6 e 12 meses, em milímetros, e resultados da ANOVA e Teste de Tukey 53

TABELA 5.15 - Valores médios e desvios padrão das medidas de margem gengival nos sítios mesial, vestibular, lingual e distal na fase cirúrgica e de controle pós-operatório de 1, 2, 3, 4, 5, 6 e 12 meses, em milímetros, e resultados da ANOVA e Teste de Tukey 54

TABELA 5.16 - Valores médios e desvios padrão de migração da margem gengival nos sítios mesial, vestibular, lingual e distal na fase de controle pósoperatório de 1, 2, 3, 4, 5, 6 e 12 meses, em milímetros, e resultados da ANOVA e Teste de Tukey 55

TABELA 5.17 - Valores médios e desvios padrão de aumento de coroa clínica aparente obtido nos sítios mesial, vestibular, lingual e distal na fase cirúrgica (pós-sutura) e de controle pós-operatório de 6 e 12 meses, em milímetros, e resultados da ANOVA e Teste de Tukey 55

TABELA 5.18 - Distribuição do número de sítios (n) e valores médios e desvios padrão $(0 \pm d p)$ de migração margem gengival para apical (valor positivo) ou coronal (valor negativo) aos 12 meses, em relação à posição do retalho supraóssea pós-sutura, em milímetros 56 
TABELA 5.19 - Teste de Correlação de Pearson entre medidas de margem gengival (MG) aos 6 e 12 meses e posição do retalho pós-sutura (Retalho), nos sítios mesial (M), vestibular (V), lingual (L) e distal (D) 56

TABELA 5.20 - Distribuição do número de sítios (n) e valores médios e desvios padrão $(0 \pm d p)$ da espessura da gengiva fina e espessa vestibular dos dentes pré-molares, em milímetros 59

TABELA 5.21 - Distribuição das papilas gengivais mesial e distal com forma côncava, aspecto stippling e "dobra" na fase pré-cirúrgica e de controle pósoperatório de 1, 2, 3, 4, 5, 6 e 12 meses, em porcentagem 59

TABELA 5.22 - Distribuição do número de cristas ósseas (n) mesial e distal e sua porcentagem (\%) de acordo com presença de lâmina dura na fase de controle pós-operatório de 2, 3, 6 e 12 meses 60

TABELA 5.23 - Valores médios e desvios padrão das medidas da distância entre término cervical e crista óssea mesial e distal na fase pré-cirúrgica, cirúrgica e de controle pós-operatório de 2, 3, 6 e 12 meses, em milímetros, e resultados da ANOVA e Teste de Tukey 60

TABELA 5.24 - Valores médios e desvios padrão das alterações no nível ósseo mesial e distal na fase cirúrgica e de controle pós-operatório de 2, 3, 6 e 12 meses, em milímetros, e resultados da ANOVA e Teste de Tukey 61

TABELA 6.1 - Valores médios das medidas de sulco gengival, epitélio juncional, inserção conjuntiva, distância biológica e tecido gengival supra-ósseo nos sítios $M, V, L$ e $D$, e média total, em dentes com nível de inserção igual a zero, em milímetros ${ }^{23}$ 79 
TABELA 6.2 - Medidas médias (desvios padrão) do tecido gengival supraósseo (análise clínica ou microscópica) e da altura do espaço interdentário (análise radiográfica) nos sítios mesial $(M)$, vestibular $(V)$, lingual $(L)$ e distal (D), de acordo com as informações colhidas na literatura 83

TABELA 6.3 - Comparação entre constituintes do espaço interdentário e componentes da "Casa da papila", e seus respectivos parâmetros clínicos ou radiográficos 95 


\section{LISTA DE ABREVIATURAS}

$$
\begin{aligned}
& \text { M - mesial } \\
& \text { V - vestibular } \\
& \text { L - lingual } \\
& \text { D - distal } \\
& \text { Da - distal adjacente } \\
& \text { Ma - mesial adjacente } \\
& \text { MG - margem gengival } \\
& \text { NIR - nível de inserção relativo } \\
& \text { JMG - junção mucogengival } \\
& \text { NO - nível ósseo } \\
& \text { NO pré - nível ósseo pré-osteotomia } \\
& \text { NO pós - nível ósseo pós-osteotomia } \\
& \text { TC - término cervical } \\
& \text { PS - profundidade de sondagem } \\
& \text { MC - mucosa ceratinizada } \\
& \text { TGS - tecido gengival supra-ósseo } \\
& \text { RO - ressecção óssea } \\
& \text { EG - espessura gengival } \\
& \text { DI - distância inter-radicular } \\
& \text { EO - exposição óssea } \\
& \text { PB - placa bacteriana } \\
& \text { IS - índice de sangramento gengival } \\
& \text { PG - papila gengival } \\
& \text { DM - distância mínima }
\end{aligned}
$$

PEM - posição estável da margem gengival 


\section{RESUMO}

O objetivo deste trabalho foi avaliar clínica e radiograficamente a reparação dos tecidos periodontais marginais em 30 dentes pré-molares, sem doença periodontal e com indicação cirúrgica para aumento de coroa com finalidade restauradora. A técnica cirúrgica executada consistiu de retalho total, osteotomia/osteoplastia para expor pelo menos de $3 \mathrm{~mm}$ de estrutura dentária saudável, reposicionamento e sutura da margem do retalho coronal à crista óssea e apical ao término cervical. $\mathrm{Na}$ avaliação clínica, medidas de margem gengival (MG), nível de inserção relativo (NIR), junção mucogengival (JMG), espessura gengival, papila gengival; presença de placa bacteriana (PB) e sangramento gengival (IS) foram obtidas antes da cirurgia e repetidas nos períodos pós-operatórios de 1, 2, 3, 4, 5, 6 e 12 meses. O uso de placa oclusal com pontos de referência fixos padronizou a localização da sonda periodontal nos sítios distal adjacente, mesial, vestibular (V), lingual (L), distal e mesial adjacente. Radiografias interproximais com posicionadores individuais foram padronizadas e realizadas antes e após cirurgia óssea, e nos períodos de 2, 3, 6 e 12 meses. Os resultados clínicos demonstraram: 1) redução significante de PB e IS aos 12 meses, exceto para sítios L; 2) nenhuma alteração significante em NIR e JMG durante período de reparação; 3) maior migração coronal da MG quanto maior a proximidade da margem do retalho pós-sutura em relação à crista óssea, para reformar a medida pré-cirúrgica do tecido gengival supraósseo (TGS); 4) nenhuma correlação entre espessura gengival e quantidade de migração da MG; 5) estabilização da $M G$ nos sítios $V$ e $L$ a partir do $4^{\circ}$ mês; 6 ) migração coronal significante da MG proximal com tendência à estabilização após 12 meses; e 7) alterações morfológicas do tecido gengival interdentário durante formação da papila gengival. Radiograficamente, lâmina dura intacta foi detectada em todas as cristas ósseas aos 12 meses, sem nenhuma alteração significante no nível ósseo durante período de reparação. Concluiuse que a estabilidade da $M G$ foi alcançada mais rapidamente ao suturar a margem do retalho no nível ou próximo à medida pré-cirúrgica de TGS. Dessa forma, sugere-se a utilização da medida pré-cirúrgica de TGS como parâmetro 
clínico para estimar a quantidade de ressecção óssea a ser realizada, monitorar as alterações da MG e determinar e prever a sua futura posição estável, após cirurgia de aumento de coroa. 
INTRODUÇÃO 



\section{INTRODUÇÃO}

O sucesso de um tratamento restaurador geralmente requer um término cervical bem definido que permite acesso à moldagem, adaptação da margem restauradora, adequado controle de placa bacteriana pelo paciente ${ }^{12,25}$, associado à manutenção da saúde dos tecidos periodontais marginais ${ }^{35}$. Quando tentativas clínicas são realizadas para restaurar um dente com presença de cárie, fratura dentária, perfuração endodôntica, reabsorção radicular ou término cervical pré-existente ${ }^{12}$ no espaço do epitélio juncional ou da inserção conjuntiva (distância biológica), podem resultar em inflamação gengival, aumento da profundidade de sondagem, perda de inserção e reabsorção óssea alveolar $r^{25,47,64,66}$. As opções de tratamento para recuperar um espaço adequado para distância biológica e para facilitar procedimentos restauradores compreendem procedimentos cirúrgico (cirurgia periodontal ressectiva com aumento de coroa) e ortodôntico (tração dentária) ${ }^{29}$.

INGBER; ROSE; COSLET ${ }^{29}$, em 1977, indicaram a técnica cirúrgica do retalho de espessura parcial posicionado apicalmente com ressecção óssea ${ }^{21}$ para aumento de coroa com finalidade restauradora. Os autores ilustraram os procedimentos cirúrgicos a serem executados, com rebatimento do retalho após duas incisões relaxantes verticais, cirurgia óssea para expor no mínimo $3 \mathrm{~mm}$ de estrutura dentária coronal à crista óssea e sutura do retalho posicionado apicalmente. Essa medida média de $3 \mathrm{~mm}$ foi estabelecida para permitir a reparação das medidas da inserção conjuntiva e epitélio juncional sobre a superfície radicular raspada ${ }^{29}$, além da formação do sulco gengival ${ }^{61}$. 
Em 2001, PONTORIERO; CARNEVALE ${ }^{49}$ confirmaram a ocorrência dessa migração coronal da margem gengival durante 12 meses, a partir do nível da margem do retalho de espessura parcial suturado ao nível ou apical à crista óssea.

LANNING et al. (2003) e DEAS et al. ${ }^{18}$ (2004) relataram a utilização de retalho de espessura total para a técnica de aumento de coroa. Com o estudo de DEAS et al. ${ }^{18}$ (2004), foi possível verificar uma correlação inversa significante entre nível pós-sutura do retalho de espessura total em relação à crista óssea e a alteração na margem gengival. Os autores evidenciaram uma menor quantidade de migração coronal da margem gengival quando o retalho foi suturado $2 \mathrm{~mm}$ ou mais coronal à crista óssea. Contudo, nenhum desses estudos clínicos longitudinais conseguiu determinar em qual período de tempo ocorreu a estabilização da margem gengival.

Dessa forma, este estudo procurou avaliar clínica e radiograficamente o processo de reparo dos tecidos periodontais marginais após cirurgia de aumento de coroa clínica em dentes pré-molares, monitorando o comportamento da margem gengival após reposicionamento e sutura dos retalhos de espessura total coronal à crista óssea e apical ao término cervical, além de analisar possíveis parâmetros clínicos e/ou radiográficos que permitam determinar a estabilidade da margem gengival, bem como, prever a futura posição da margem e a formação da papila gengival. 
REVISÃO DA LITERATURA 



\section{REVISÃO DA LITERATURA}

BRÄGGER; LAUCHENAUER; LANG ${ }^{12}$ (1992) avaliaram alterações nos níveis dos tecidos periodontais imediatamente após realização de procedimento cirúrgico de aumento de coroa e ao longo de um período de 6 meses, em 25 pacientes (idade entre 20 e 81 anos). Após terapia inicial, a cirurgia de aumento de coroa foi realizada para melhorar a retenção da coroa protética e obter acesso às margens do preparo localizado subgengivalmente que comprometiam a realização da moldagem. Os retalhos e cirurgia óssea foram executados de acordo com a técnica descrita por INGBER; ROSE; COSLET $^{29}$, obtendo-se uma distância de pelo menos $3 \mathrm{~mm}$ entre término cervical e crista óssea alveolar reduzida. Ao final, os retalhos foram bem adaptados e o controle químico da placa bacteriana foi realizado com bochecho de clorexidina a $0,1 \%$ por 2 semanas. Após 3 semanas, os procedimentos de reconstrução dentária foram iniciados e a maioria dos dentes testes receberam coroas protéticas durante período de avaliação. Os dentes controles foram selecionados no quadrante contralateral e não receberam procedimento cirúrgico. De um total de 85 dentes, 43 dentes testes (7 incisivos, 8 caninos, 20 pré-molares e 8 molares) e 42 dentes controles foram reavaliados após 6 semanas e 6 meses da cirurgia, em 6 sítios por dente, com relação a: índice de placa de SILNESS; LÖE ${ }^{60}$ (1964), índice gengival de LÖE; SILNESS ${ }^{37}$ (1963) e medida das distâncias de uma placa oclusal (ponto de referência) até margem gengival, base da bolsa e crista óssea alveolar. Essas distâncias foram mensuradas com padronização da localização da sonda periodontal em sulcos de orientação confeccionados na placa acrílica. Os dados obtidos 
demonstraram que não houve diferença significativa no índice de placa (entre 0,27 e 0,52), índice gengival (entre 0,78 e 0,92) e profundidade de sondagem entre os períodos de observação inicial e 6 meses e entre os grupos teste e controle. A medida média de sondagem inicial de $1,89 \mathrm{~mm}$ aumentou para $2,24 \mathrm{~mm}$ nos sítios testes e de 2,07mm para 2,59mm nos sítios controles, aos 6 meses. A ressecção óssea de 1, 2 e $\geq 3 \mathrm{~mm}$ foi observada em 68 (32\%), 43 (21\%) e 9 sítios (4\%), respectivamente, e em 79 sítios (38\%) não houve alteração no nível ósseo. A redução no nível de inserção $(1,4 \mathrm{~mm})$ foi estatisticamente significante entre o exame inicial e 6 semanas, sem alteração significativa entre 6 semanas e 6 meses, no grupo teste. No grupo controle, não foi verificada diferença estatisticamente significante no nível de inserção entre as medidas obtidas. A comparação entre os grupos teste e controle em relação à alteração no nível de inserção, demonstrou diferença estatisticamente significante somente entre o período inicial e 6 semanas, com $81 \%$ dos sítios testes com perda de inserção de 1 a $4 \mathrm{~mm}$ e $30 \%$ dos sítios, no grupo controle. A média de migração apical da margem gengival imediatamente após a sutura foi de $1,32 \mathrm{~mm}$, sem diferenças significativas entre 6 semanas $(1,47 \mathrm{~mm})$ e 6 meses $(1,37 \mathrm{~mm})$. As alterações médias na margem gengival não foram significantes nos sítios controles entre o exame inicial e os períodos de avaliação. A comparação da distribuição dos sítios controles e testes com alteração na margem gengival foi significante entre o exame inicial e 6 semanas, com migração apical de 1 a 4mm em 77,5\% (161) dos sítios testes e em 44\% (59) dos sítios controles. A migração coronal máxima de $1 \mathrm{~mm}$ da margem gengival foi observado em 2,5\% (5) dos sítios testes e 29\% (39) dos sítios controles, enquanto a margem gengival manteve-se inalterada em $20 \%$ (41) e $27 \%$ (36) dos sítios testes e controles, respectivamente. A diferença entre margem gengival estabelecida após sutura e após 6 semanas nos sítios testes não foi estatisticamente significante entre medida inicial e 6 semanas nos sítios controles. No intervalo entre 6 semanas e 6 meses, a distribuição dos sítios com alterações na margem gengival também não demonstrou diferença significante entre sítios testes e controles. A partir desses resultados, os autores concluíram que a posição da margem gengival livre após 6 meses da cirurgia foi determinada pela posição do retalho no momento da sutura. 
HERRERO et al. ${ }^{28}$ (1995) verificaram se a medida de $3,0 \mathrm{~mm}$ entre a margem da restauração planejada e a crista alveolar era rotineiramente obtida por profissionais após procedimento cirúrgico de aumento de coroa. Os autores avaliaram também a efetividade clínica dos profissionais de acordo com o grau de experiência. Após as instruções de higiene bucal, 16 pacientes com ótimo controle de placa foram incluídos no estudo, totalizando 21 dentes com indicação de aumento de coroa. Diferentes cirurgiões (4 professores, 4 estudantes do $1^{\circ}$. ano e 4 do $2^{\circ}$. ano) realizaram as técnicas cirúrgicas, que consistiram de gengivectomia ou retalho posicionado apicalmente com e sem ressecção óssea. Utilizando uma placa oclusal como referência, um outro profissional calibrado obteve medidas nos sítios vestibular, mésio-vestibular, lingual e disto-lingual dos dentes tratados antes e após redução óssea. Nenhuma modificação no preparo dos dentes foi realizada antes da $8^{a}$ semana, a fim de preservar os pontos de referência para as medições dos seguintes parâmetros clínicos: posição da margem gengival, profundidade de sondagem, posição do término cervical do preparo, nível da junção mucogengival, localização da crista alveolar, mobilidade, índice de placa de O'LEARY (1967) e índice gengival de LÖE; SILNESS ${ }^{37}$ (1963). Estas medidas foram novamente registradas 8 semanas após cirurgia, com exceção da medida da crista óssea. Os resultados não mostraram alteração estatisticamente significante a partir dos parâmetros clínicos iniciais ou entre operadores com experiência variada.

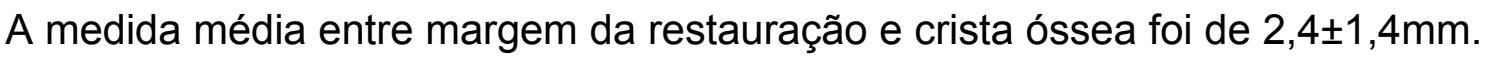
Essa distância foi maior nos sítios vestibular (média 2,6 $\pm 1,2 \mathrm{~mm}$ ) dos dentes, seguidos pelos sítios mésio-vestibular $(2,4 \pm 1,0 \mathrm{~mm})$, lingual $(2,3 \pm 1,5 \mathrm{~mm})$ e disto-lingual $(2,2 \pm 1,7 \mathrm{~mm})$. Apesar dos cirurgiões mais experientes removerem uma maior quantidade de osso $(1,1 \pm 0,6 \mathrm{~mm})$ do que outros cirurgiões (estudantes de $1^{\circ}$. e $2^{\circ}$. ano removeram, em média, $0,0 \pm 0,7 \mathrm{~mm}$ e $0,8 \pm 0,5 \mathrm{~mm}$, respectivamente), não foi encontrada nenhuma correlação entre o nível de experiência e a distância obtida. A quantidade média de gengiva inserida vestibular antes e 8 meses após cirurgia foi de 2,5 $\pm 1,2 \mathrm{~mm}$ (de 0,0 a 4,0 mm) e $2,3 \pm 1,3 \mathrm{~mm}$ (de 0,5 a 5,0mm), respectivamente. Os autores concluíram que a distância biológica de $3 \mathrm{~mm}$ não foi rotineiramente alcançada, por meio da cirurgia de aumento de coroa, mesmo por profissionais especializados. 
OAKLEY et al. $^{43}$ (1999) determinaram se e como a distância biológica é restabelecida após cirurgia de aumento de coroa, em 3 macacos Rhesus (Macaca mulatta) adultos jovens (com peso entre 7 e 10kg). Os procedimentos cirúrgicos foram realizados em dentes de um quadrante superior e um inferior, selecionados aleatoriamente, com o dente contralateral servindo como controle, sem cirurgia. Após a incisão, os retalhos mucoperiósteos foram rebatidos e a osteotomia foi executada ao redor dos dentes com instrumentos rotatórios e manuais até obter uma distância de 4 a $6 \mathrm{~mm}$ da junção cemento-esmalte (JCE) até a crista óssea. Em seguida, as superfícies radiculares dos dentes foram alisadas para remover todo o ligamento periodontal e o cemento radicular, e os retalhos foram posicionados e suturados apicalmente, deixando a crista óssea proximal exposta. As suturas foram removidas após 1 semana e o controle de placa pós-cirúrgico foi realizado com cotonete (faces livres) e escova interdental (faces proximais) embebidos em clorexidina a 2\%, 3 vezes por semana. Após 12 semanas da cirurgia, os animais foram submetidos a eutanásia e blocos de tecido foram removidos para a análise histométrica, avaliando a distância linear da crista óssea até a margem gengival, da crista gengival até a extensão apical do epitélio juncional e do nível apical da superfície radicular alisada até a crista óssea. As medidas obtidas por meio dessa análise histométrica indicaram que: 1) a extensão apical do epitélio juncional estava localizada ao nível da JCE ou no cemento nos sítios controles, e no cemento em todos os sítios experimentais; 2) a crista óssea marginal dos sítios experimentais apresentouse mais larga e plana quando comparada aos sítios controles; 3) o epitélio juncional migrou para o nível mais apical da superfície radicular alisada; 4) a altura do tecido gengival supra-ósseo nos sítios experimentais maxilares $(1,56 \pm 0,21 \mathrm{~mm})$ foi menor em relação aos sítios controles $(2,25 \pm 0,43 \mathrm{~mm})$, enquanto que a medida do tecido gengival supra-ósseo nos sítios experimentais mandibulares $(2,62 \pm 0,45 \mathrm{~mm})$ foi maior do que nos sítios controles $(2,50 \pm 0,58 \mathrm{~mm}) ; 5)$ os sítios da maxila apresentaram uma reabsorção

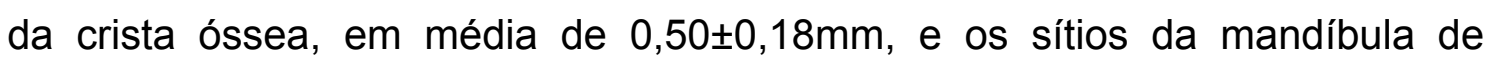
$0,77 \pm 0,85 \mathrm{~mm}$; 6) a medida da inserção de tecido conjuntivo supra-ósseo correlacionou-se com a quantidade de reabsorção óssea, variando de 
$0,63 \pm 0,19 \mathrm{~mm}$ e $0,86 \pm 0,35 \mathrm{~mm}$, respectivamente para os sítios maxilares e mandibulares. A reabsorção pós-cirúrgica da crista óssea alveolar criou um espaço para tecido conjuntivo supra-ósseo com grupos de fibras orientadas perpendicularmente à superfície do cemento. Os resultados indicaram que a distância biológica reduzida foi restabelecida apicalmente após a cirurgia de aumento de coroa clínica e a formação de fibras transeptais orientadas funcionalmente foi facilitada pela reabsorção da crista óssea apicalmente ao nível da raiz alisada.

PONTORIERO; CARNEVALE ${ }^{49}$, em 2001, analisaram as alterações dos tecidos periodontais marginais após procedimentos cirúrgicos de aumento de coroa por um período de 12 meses. A amostra consistiu de 30 pacientes (84 dentes), entre 19 a 62 anos de idade (média de 40,5 anos), com 1 ou mais dentes com necessidade de cirurgia periodontal ressectiva para expor estrutura dentária saudável com finalidade restauradora e estética. Após terapia inicial, os pacientes foram submetidos ao exame inicial, em 4 sítios (centro das faces mesial, distal, vestibular e lingual) por dente, com avaliação dos seguintes parâmetros: índice de placa de SILNESS; LÖE60 (1964), índice gengival de LÖE; SILNESS ${ }^{37}$ (1963), posição da margem gengival, profundidade de sondagem e nível de inserção. Para padronização das medidas com sonda periodontal, marcações circulares ou sulcos verticais foram preparados no dente/raiz para servirem como pontos de referência. Uma avaliação prévia do biotipo tecidual de cada paciente foi realizada, classificando em normal, fino ou espessa. Durante a cirurgia, um retalho de espessura parcial vestibular e lingual foi rebatido, seguido da remoção do tecido mole supra-ósseo e realização de osteotomia e osteoplastia com cinzéis manuais ou pontas diamantadas. Durante este procedimento, a quantidade de ressecção óssea e o aumento de coroa clínica obtida foram registrados. Os retalhos vestibular e lingual foram subseqüentemente posicionados ao nível ou apical à crista óssea alveolar e estabilizados com suturas ancoradas no periósteo, expondo completamente a crista óssea proximal. A sutura e o cimento cirúrgico foram removidos após 10 dias e todos os pacientes foram incluídos no programa de manutenção com profilaxia dentária profissional a cada 2 semanas nos 3 
primeiros meses e a cada 4 semanas nos 9 meses restantes. A reavaliação dos parâmetros clínicos foi realizada nos períodos pós-operatórios de 1, 3, 6, 9 e 12 meses. Os resultados demonstraram que: 1) imediatamente após a cirurgia, um significante aumento de coroa clínica de $3,7 \pm 0,8 \mathrm{~mm}$ e $4,1 \pm 0,9 \mathrm{~mm}$ foi obtido nos sítios proximais e vestibular/lingual, respectivamente; 2) durante todo o processo de reparo, as médias dos escores do índice gengival e de placa permaneceram estáveis tanto nos sítios proximais $(0,7$ e 0,4$)$ como nos sítios vestibular/lingual $(0,4$ e 0,3$) ; 3)$ enquanto os valores médios da profundidade de sondagem não apresentaram diferença estatisticamente significante entre as medidas inicial e final, a perda média de inserção clínica foi de $0,6 \pm 0,7 \mathrm{~mm}$ e $1,1 \pm 0,9 \mathrm{~mm}$ para os sítios proximais e vestibular/lingual, respectivamente; 4) houve uma migração coronal estatisticamente significante da margem gengival de $3,2 \pm 0,8 \mathrm{~mm}$ e $2,9 \pm 0,6 \mathrm{~mm}$, respectivamente, para os sítios proximais e vestibular/lingual e 5) como uma conseqüência deste crescimento tecidual pós-cirúrgico, a quantidade de estrutura dentária disponível imediatamente após cirurgia diminuiu para $0,5 \pm 0,6 \mathrm{~mm}$ nos sítios proximais e para $1,2 \pm 0,7 \mathrm{~mm}$ nos sítios vestibular/lingual após 12 meses de avaliação. Os autores observaram que durante todo período de um ano, os tecidos periodontais marginais mostraram uma tendência para crescimento coronal a partir do nível determinado imediatamente após sutura. Este crescimento coronal da margem gengival foi influenciado pelo biotipo tecidual, sendo mais pronunciado nos pacientes com biotipo espesso (sítios proximais: $3,6 \pm 0,5 \mathrm{~mm}$; sítios vestibular/lingual: $3,1 \pm 0,8 \mathrm{~mm}$ ) do que com fino (sítios proximais: $2,8 \pm 0,7 \mathrm{~mm}$; sítios vestibular/lingual: $2,6 \pm 0,4 \mathrm{~mm}$ ), e pelas variações biológicas individuais não relacionadas à idade e ao gênero.

DIBART et al. $^{19}$ (2003), numa análise retrospectiva, avaliaram radiograficamente os resultados após cirurgia de aumento de coroa em molares inferiores executada previamente à colocação das coroas protéticas. Um total de 45 pacientes (18 homens e 27 mulheres) com idade média de 47,9 anos (31 a 71 anos), sem doença periodontal, foi selecionado e dividido em dois grupos: grupo teste - 26 indivíduos com 26 molares inferiores (19 primeiros molares e 7 segundos molares) necessitando de cirurgia previamente 
à colocação de coroas protéticas; e grupo controle - 19 indivíduos com 24 coroas protéticas em molares inferiores (17 primeiros molares e 7 segundos molares), sem necessidade de cirurgia. O procedimento cirúrgico de aumento de coroa restabeleceu a medida de $3 \mathrm{~mm}$ coronal à crista óssea para permitir reparação, recuperação do espaço para distância biológica e restauração adequada do dente dentro de um período de um ano. As radiografias interproximais realizadas previamente à cirurgia (grupo teste) ou à colocação da coroa (grupo controle) e 5 anos após a cimentação das próteses foram padronizadas para obter mínima distorção e medidas precisas. A análise radiográfica comparou o envolvimento de furca determinado pela presença de área radiolúcida na furca e a distância da furca até o término cervical entre os dois grupos, cuja mensuração foi realizada por meio de uma grade plástica com $1 \mathrm{~mm}$ de intervalo. Nenhum dos 24 molares inferiores do grupo controle demonstrou evidência radiográfica de envolvimento de furca. Dos 26 dentes do grupo teste, 10 (38,5\%) apresentaram evidência radiográfica de lesões de furca, sendo $80 \%$ da ocorrência em primeiro molares inferiores. Os dentes controles apresentaram uma distância da furca até a margem da coroa protética significativamente maior do que os dentes testes. Todos os dentes testes com uma distância pré-cirúrgica $<4 \mathrm{~mm}$ entre a furca e o término cervical da coroa desenvolveram lesão de furca, enquanto nenhum molar com distância $>4 \mathrm{~mm}$ mostrou sinal de envolvimento de furca. Dos 4 dentes testes com distância da furca igual a $4 \mathrm{~mm}$, somente um molar $(25 \%)$ resultou em envolvimento de furca. Baseado nesses resultados, os autores estabeleceram uma distância limite da furca até o término cervical de $4 \mathrm{~mm}$ em molares inferiores com indicação de cirurgia de recuperação de espaço para distância biológica, para diminuir a probabilidade de futuro envolvimento de furca.

LANNING et al. ${ }^{35}$ (2003) propuseram avaliar as alterações na posição dos tecidos periodontais, particularmente da distância biológica, após cirurgia de aumento de coroa em 23 pacientes ( 28 a 72 anos de idade). Após profilaxia profissional e instruções de higiene bucal, foram confeccionadas placas em resina acrílica com sulcos verticais nos sítios mésio-vestibular, distovestibular, mésio-lingual e disto-lingual para padronizar a localização e 
angulação da sonda periodontal. Os seguintes parâmetros: índice gengival de LÖE; SILNESS ${ }^{37}$ (1963), índice de placa de SILNESS; LÖE60 (1964), distância entre a referência na placa de acrílico e a margem gengival livre, profundidade de sondagem, nível de inserção (distância entre a placa e a base da bolsa), nível ósseo (distância entre a placa e a medida da sonda periodontal tocando a crista óssea), nível ósseo direto (medida da placa até a crista óssea após rebatimento do retalho) e medida da distância biológica (subtração entre a medida do nível ósseo e do nível de inserção) foram obtidos à partir da linha angular (limite entre duas superfícies axiais) dos dentes tratados (sítios tratados) e dos dentes adjacentes, considerados como sítios adjacentes e nãoadjacentes (sítios proximais distantes dos dentes tratados). Durante a cirurgia, a redução no nível ósseo baseou-se na medida da distância biológica obtida previamente à cirurgia. Os retalhos de espessura total foram posicionados e suturados ao nível da crista óssea. Os pacientes foram examinados na fase pré-cirúrgica e 3 e 6 meses após cirurgia, além de participarem do programa de manutenção periodontal, sendo que nenhum tratamento protético foi iniciado antes de 6 semanas após cirurgia. No período de 3 e 6 meses, os pacientes foram anestesiados para obtenção das medidas clínicas. Dos 23 pacientes apenas 19 completaram o estudo, com 98\% dos dentes tratados com prótese fixa até o final do estudo. Não foi observada nenhuma variação significativa no índice de placa $(0,41$ a 0,62$)$ e gengival $(0,34$ a 0,73$)$ em qualquer sítio em todo o período de avaliação. A quantidade de osso removido variou de 1 a $5 \mathrm{~mm}$, sendo que em $90 \%$ dos sítios tratados foram removidos $3 \mathrm{~mm}$ ou mais. A alteração média no nível ósseo foi de 1,58mm, 1,84mm e 2,68mm, respectivamente, nos sítios não adjacentes, adjacentes e tratados. A alteração no nível ósseo entre o período pós-osteotomia e aos 3 meses foi de $0,87 \mathrm{~mm}$, 0,69mm e 0,77mm, respectivamente, nos sítios não adjacentes, adjacentes e tratados, e entre 3 e 6 meses não foi observada nenhuma alteração. Uma significante migração apical da margem gengival foi observada após 3 e 6 meses em relação ao nível pré-cirúrgico, em média, de 2,46 $00,25 \mathrm{~mm}$ e

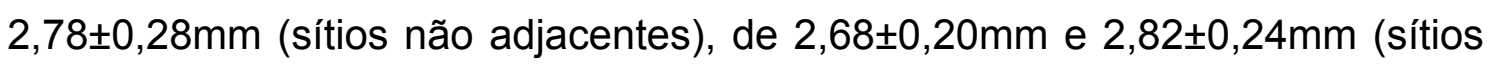
adjacentes) e de $3,07 \pm 0,16 \mathrm{~mm}$ e $3,33 \pm 0,15 \mathrm{~mm}$ (sítios tratados), respectivamente. Não houve alteração significativa na posição da margem 
gengival livre e nível de inserção entre 3 e 6 meses. A perda de inserção foi de $2,71 \pm 0,96 \mathrm{~mm}, 2,92 \pm 0,92 \mathrm{~mm}$ e $3,57 \pm 0,70 \mathrm{~mm}$, respectivamente, nos sítios não adjacentes, adjacentes e tratados. A profundidade de sondagem não apresentou alteração significativa para os sítios não adjacentes (de $2,53 \mathrm{~mm}$ para $2,49 \mathrm{~mm}$ ), adjacentes (de $2,57 \mathrm{~mm}$ para $2,53 \mathrm{~mm}$ ) e tratados (de $2,30 \mathrm{~mm}$ para $3,17 \mathrm{~mm}$ ) entre medida inicial e 6 meses. A medida média da distância biológica foi menor aos 6 meses quando comparada à medida pré-cirúrgica, tanto nos sítios não adjacentes (de 2,36mm para 2,14mm) como nos sítios adjacentes (de 2,23mm para 2,08mm), exceto para os sítios tratados, cuja medida pré-cirúrgica foi restabelecida (de $2,26 \mathrm{~mm}$ para $2,19 \mathrm{~mm}$ ). Os autores sugeriram que: 1) o repreparo do término cervical definitivo poderia ser realizado após 3 meses, com restabelecimento da medida da distância biológica por meio de procedimentos cirúrgicos ressectivos; e 2) mais estudos clínicos deveriam ser realizados para avaliar alterações da margem gengival por um período superior a 6 meses.

DEAS et al. $^{18}$, em 2004, analisaram a estabilidade dos procedimentos cirúrgicos de aumento de coroa executados por vários cirurgiões, utilizando parâmetros específicos para determinar o ponto final da cirurgia. Vinte e cinco pacientes (18 homens e 7 mulheres) foram incluídos na amostra, totalizando 43 dentes submetidos à cirurgia periodontal de aumento de coroa. Parâmetros clínicos, como índice de placa, índice de sangramento à sondagem, profundidade de sondagem e nível de inserção relativo, foram registrados a partir de uma placa oclusal em oito sítios para cada molar e em seis sítios para cada pré-molar. Nesses mesmos sítios, após elevação de um retalho de espessura total, medidas cirúrgicas foram obtidas da placa até o nível ósseo alveolar, antes e após osteotomia, e a distância do nível ósseo até a margem do retalho foi medida após a sutura. Os parâmetros estabelecidos para determinar o ponto final da cirurgia foram: localizar a crista óssea pelo menos $3 \mathrm{~mm}$ apical à margem da coroa, obter pelo menos $9 \mathrm{~mm}$ de altura da coroa clínica coronal à crista óssea e posicionar a margem do retalho póssutura ao nível ou apical à margem da restauração. As medidas clínicas foram repetidas após 1,3 e 6 meses da cirurgia. Do total, 24 pacientes foram 
examinados. A estatística descritiva não revelou diferença significante nos índices de placa e de sangramento durante todo período de avaliação e entre diferentes sítios. Nos sítios ao redor do dente a ser tratado (TT) foi observado um aumento médio da coroa clínica ao término da cirurgia de 2,27 $\pm 1,1 \mathrm{~mm}$, reduzindo para $1,91 \pm 1,08 \mathrm{~mm}, 1,69 \pm 1,02 \mathrm{~mm}$ e $1,57 \pm 1,01 \mathrm{~mm}$, respectivamente, após 1, 3 e 6 meses. Nos sítios proximais localizados nos dentes adjacentes (AA) ao dente a ser tratado, o aumento de coroa foi de 2,18 $\pm 0,98 \mathrm{~mm}$, $1,61 \pm 0,98 \mathrm{~mm}, 1,43 \pm 0,96 \mathrm{~mm}$ e 1,30 $\pm 0,96 \mathrm{~mm}$ imediatamente após cirurgia, 1, 3 e 6 meses, respectivamente; e os sítios proximais opostos nos dentes adjacentes (AN), distantes do molar ou pré-molar a ser tratado, exibiram um aumento da coroa de $1,06 \pm 1,07 \mathrm{~mm}$ ao final da cirurgia, reduzindo para $1,00 \pm 0,93 \mathrm{~mm}$ após 1 mês, $0,84 \pm 1,00 \mathrm{~mm}$ após 3 meses e $0,76 \pm 0,85 \mathrm{~mm}$ póos 6 meses. A média de redução óssea foi de $1,13 \pm 0,9 \mathrm{~mm}$ para sítios TT, $0,78 \pm 0,75 \mathrm{~mm}$ para sítios $A A$ e $0,065 \pm 0,69 \mathrm{~mm}$ para sítios $A N$. A freqüência de distribuição revelou 44,3\% dos sítios TT com $1 \mathrm{~mm}$ de ressecção óssea, 25,4\% com $2 \mathrm{~mm}, 6,2 \%$ com $3 \mathrm{~mm}$ e menos do que $1 \%$ com $\geq 4 \mathrm{~mm} ; 23,6 \%$ não apresentaram alteração no nível ósseo. A comparação entre os níveis da margem gengival demonstrou que quanto mais próximo o retalho for suturado da crista alveolar, maior o crescimento coronal durante processo de reparo. A migração média coronal da margem gengival foi de $1,25 \pm 1,06 \mathrm{~mm}$, $0,84 \pm 0,87 \mathrm{~mm}, 0,58 \pm 0,78 \mathrm{~mm}$ e $-0,12 \pm 1,33 \mathrm{~mm}$, respectivamente, com retalho posicionado $\leq 1 \mathrm{~mm}, 2 \mathrm{~mm}, 3 \mathrm{~mm}$ e $\geq 4 \mathrm{~mm}$ coronal à crista óssea nos sítios TT. A estabilidade da margem gengival não foi alcançada dentro do período de 6 meses. Os dados obtidos demonstraram uma correlação inversa entre a posição do retalho no momento da sutura e a quantidade de migração coronal do tecido gengival após cirurgia de aumento de coroa. 
PROPOSIÇÃO 



\section{PROPOSIÇÃO}

Este estudo longitudinal de 12 meses de avaliação do processo de reparo dos tecidos periodontais marginais, após cirurgia de aumento de coroa com finalidade restauradora, teve o propósito de:

1) monitorar clinicamente as alterações no nível da margem gengival após reposicionamento e sutura dos retalhos de espessura total aproximadamente $2 \mathrm{~mm}$ coronal à crista óssea;

2) analisar radiograficamente as alterações nas cristas ósseas proximais;

3) verificar parâmetros clínicos e/ou radiográficos que permitam determinar a estabilidade da margem gengival. 

MATERIAL EMÉTODOS 



\section{MATERIAL E MÉTODOS}

A execução desta pesquisa clínica, realizada após aprovação pelo Comitê de Ética em Pesquisa em Seres Humanos da Faculdade de Odontologia de Bauru - USP em 31 de março de 2004 (Anexo 1), baseou-se nas normas da resolução 196 do Conselho de Saúde do Ministério da Saúde Pública e Código de Ética Profissional Odontológico, conforme Resolução CFO $179 / 73^{68}$.

\section{1 - Seleção da amostra}

Pacientes com indicação para cirurgia de aumento de coroa com finalidade restauradora foram encaminhados pelo Serviço de Triagem das Clínicas do Curso de Graduação e Pós-graduação da Faculdade de Odontologia de Bauru - USP. A amostra de pacientes com idade entre 20 e 45 anos, sem distinção de gênero ou raça, deveria incluir dentes pré-molares superiores e/ou inferiores com coroa clínica curta ou invasão do espaço da distância biológica pela cárie, fratura dentária, término cervical pré-existente, perfuração endodôntica ou reabsorção dentinária ${ }^{12}$, distantes da crista óssea alveolar até $2 \mathrm{~mm}^{25}$.

Os critérios de exclusão foram:

- Quantidade de mucosa ceratinizada vestibular $<2 \mathrm{~mm}^{34}$;

- Presença de doença periodontal ${ }^{19}$; 
- Alterações sistêmicas que pudessem comprometer o processo de reparo $^{31}$;

- Gestante e lactante ${ }^{41}$;

- Fumante;

- Usuário de imunossupressores, anticonvulsivante ou bloqueadores de cálcio $^{41}$;

- Alérgico a iodo;

- Indivíduo submetido a tratamento cirúrgico periodontal na área nos últimos doze meses ${ }^{49}$.

Cada paciente recebeu uma carta com informações e esclarecimentos sobre a pesquisa e os procedimentos a serem efetuados e assinou um termo de consentimento livre e esclarecido em concordância de participar da pesquisa proposta e um termo de permissão para uso de informações (fotografias, registros clínicos, imagens de órgãos e espécimes) para pesquisa, artigo científico e fins didáticos.

\section{2 - Avaliação inicial da amostra}

A avaliação periodontal inicial de cada paciente selecionado, realizada por um profissional especializado (Examinador 1), incluiu:

- Medida da profundidade de sondagem, realizada com sonda periodontal milimetrada PCPUNC-15 (Hu-friedy ${ }^{\circledR}$, Rio de Janeiro, Brasil) em quatro sítios: centro das faces mesial (M), vestibular $(V)$, lingual (L) e distal (D) ${ }^{49}$;

- Índice de sangramento gengival proposto por AINAMO; BAY2 (1975) nos sítios $M, V, L$ e D. O número de sítios com sangramento, observado dentro de 10 segundos após sondagem 
do sulco gengival, foi expresso em porcentagem do número de sítios examinados;

- Evidenciação da placa bacteriana com solução de verde de malaquita a $1 \%$ nos sítios $\mathrm{M}, \mathrm{V}, \mathrm{L}$ e $\mathrm{D}$. O número de sítios com placa foi expresso em porcentagem do número de sítios examinados;

- Tomada radiográfica periapical do dente pré-molar pela técnica do paralelismo, utilizando posicionadores XCP $\operatorname{Rinn}^{\circledR}$ (Rinn Corporation, Illinois, USA);

- Documentação fotográfica clínica (máquina fotográfica Nikon ${ }^{\circledR}$ N50, objetiva macro $105 \mathrm{~mm})$.

\section{3 - Padronização da amostra}

Todos os pacientes selecionados foram submetidos ao preparo inicial, incluindo:

- Orientação de higiene bucal: técnica de escovação de Bass $^{5}$ e uso de escova dental macia Bitufo ${ }^{\circledR}$ (Comercial Maripa Ltda, Jundiaí, Brasil), fio dental, escova unitufo macia Bitufo ${ }^{\circledR}$ e escova interdental cilíndrica extra fina $n^{\circ} .3$ ou $4\left(\right.$ Bitufo $\left.^{\circledR}\right)$;

- Raspagem manual supra e subgengival boca toda com curetas de Gracey padrão e mini five (Hu-Friedy ${ }^{\circledR}$, Rio de Janeiro, Brasil) ${ }^{31}$;

- Quando necessário, eliminação de interferências oclusais e/ou contatos prematuros, remoção de excesso de restaurações ${ }^{12} \mathrm{e}$ tratamento ou retratamento endodôntico;

- Confecção de restauração ou coroa provisória previamente à cirurgia ${ }^{69}$. 
O número e a freqüência das sessões de reforço às instruções de higiene bucal e evidenciação de placa foram estabelecidos de acordo com as dificuldades individuais.

\section{4 - Avaliação clínica}

\subsection{1- Confecção da Placa Oclusal (guia)}

Uma moldagem da arcada dentária com hidrocolóide irreversível Jeltrate $^{\circledR}$ (Dentsply Ind. Com. Ltda, Petrópolis, São Paulo) foi realizada para reprodução de modelos em gesso pedra e confecção de uma placa oclusal (guia) em resina acrílica ativada quimicamente Jet Clássico ${ }^{\circledR}$ (Artigos Odontológicos Clássico Ltda, São Paulo, Brasil), estendendo-se um dente para mesial e distal do dente pré-molar a ser tratado (Figura 4.1-A). Após o desgaste da placa acrílica para obter uma superfície oclusal plana, os pontos ou sulcos verticais de referência fixos foram realizados com ponta diamantada cilíndrica $n^{\circ}$. 1090 (KG-Sorensen ${ }^{\circledR}$ ) para contra-ângulo, na direção ocluso-apical, em quatro sítios para cada pré-molar a ser tratado (centro das faces mesial $(\mathrm{M})$, vestibular $(V)$, lingual $(L)$ e distal $(D)^{49}$ ) e em um sítio proximal para cada dente adjacente ao pré-molar (Ma ou Da) (Figura 4.1-A e B). A placa oclusal foi ajustada intrabucalmente para confirmar a localização dos pontos de referência. Esses pontos foram utilizados como guia para a localização e angulação da sonda periodontal milimetrada, e a superfície oclusal da placa serviu como stop para um cursor endodôntico (Figura 4.1-C).

Após cada utilização clínica, a placa oclusal foi acondicionada em pote plástico individual, identificado e preenchido com água e hipoclorito de sódio com $2 \%$ de cloro ativo estabilizado (Virex ${ }^{\circledR}$ plus $2 \%$, Ceras Johnson Ltda, Rio de Janeiro, Brasil) para manter a estabilidade da resina acrílica e impedir o crescimento de culturas de microrganismos. 

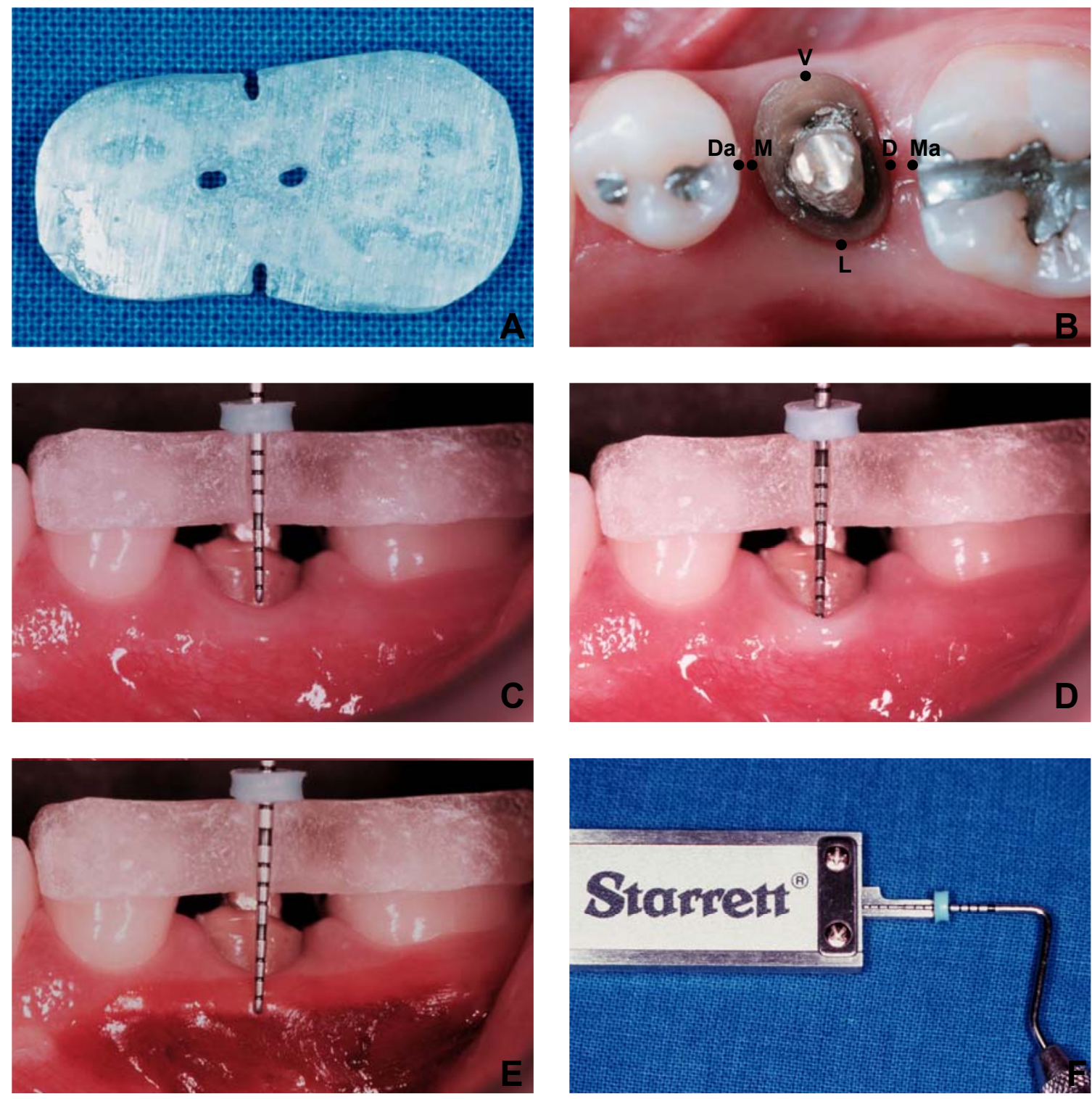

FIGURA 4.1 - Avaliação clínica. (A) Placa oclusal (guia) confeccionada em resina acrílica com pontos ou sulcos de referência fixos, (B) para obtenção de medidas clínicas em 6 sítios (• ): quatro sítios no pré-molar a ser tratado, centro das faces mesial (M), vestibular (V), lingual (L) e distal (D); e dois sítios nos dentes adjacentes, um no centro da face distal do dente localizado à mesial (Da) e outro, no centro da face mesial do dente localizado à distal (Ma) do pré-molar a ser tratado. (C) Localização da sonda periodontal milimetrada no sulco de referência vestibular, com a superfície oclusal plana da placa servindo como stop para cursor endodôntico. (D) Medida clínica do nível de inserção relativo e (E) da junção mucogengival vestibular, após aplicação de solução de Schiller. (F) A mensuração da medida obtida com sonda milimetrada e cursor foi realizada por meio do paquímetro digital Starrett ${ }^{\circledR}$. 



\subsection{2 - Parâmetros Clínicos}

Os parâmetros clínicos utilizados na pesquisa e sua seqüência estão descritos na Figura 4.2 e Tabela 4.1.

As seguintes medidas clínicas foram obtidas pelo mesmo profissional (Examinador 1), com auxílio da placa oclusal e sonda periodontal milimetrada PCPUNC-15 (Hu-friedy ${ }^{\circledR}$, Rio de Janeiro, Brasil) com cursor endodôntico Angelus ${ }^{\circledR}$ (Odonto-Lógika, Londrina, Brasil) ${ }^{28}$ :

- Margem gengival (MG) - distância da superfície oclusal da placa até margem gengival nos sítios $M, V, L$ e $D$;

- Nível de inserção relativo (NIR) - distância da superfície oclusal da placa até fundo do sulco gengival clínico nos sítios $D a, M, V, L$, D e Ma (Figura 4.1-D);

- Junção mucogengival (JMG) - distância da superfície oclusal da placa até junção mucogengival vestibular demarcada após aplicação de solução de Schiller $^{34}$ (Figura 4.1-E);

- Nível ósseo (NO) - distância da superfície oclusal da placa até crista óssea alveolar ${ }^{49}$, nos sítios Da, M, V, L, D e Ma;

- Término cervical (TC) - distância da superfície oclusal da placa até término cervical do preparo nos sítios $M, V, L$ e $D$;

As medidas obtidas com sonda milimetrada e cursor endodôntico foram mensuradas com um paquímetro digital (Starrett ${ }^{\circledR}$ modelo 727, Brasil) (Figura 4.1-F), com acurácia de centésimo de milímetros, por um outro profissional especializado (Examinador 2). A média entre duas medições foi considerada, permitindo minimizar o erro inerente ao método. 
A partir destas medidas clínicas, outras foram obtidas, como:

- Profundidade de sondagem (PS) - subtração da medida de NIR e MG, nos sítios $M, V$, L e D;

- Mucosa ceratinizada (MC) - subtração da medida de JMG e MG do sítio $\mathrm{V}^{28}$

- Localização do término cervical em relação à margem gengival subtração da medida de TC e MG nos sítios M, V, L e D, com valor negativo para nível subgengival (Figura 4.2 - a) e valor positivo para nível supragengival (Figura 4.2 - a' e a');

- Distância do término cervical até crista óssea - subtração da medida de NO e $\mathrm{TC}^{28}$ nos sítios M, V, L e D (Figura 4.2 - b e b');

- Tecido gengival supra-ósseo (TGS) - subtração da medida de NO e MG nos sítios M, V, L e D (Figura 4.2 - c, c' e c");

- Aumento de coroa clínica aparente obtida - subtração da medida de MG pré e pós-cirúrgico (MG pós-sutura e MG de 1 a 12 meses) nos sítios M, V, L e D (Figura 4.2 - d e d');

- Ressecção óssea (RO) - obtida pela diferença entre medidas de NO obtidas antes (NO pré) e após osteotomia (NO pós) ${ }^{28,49}$, nos sítios Da, M, V, L, D e Ma (Figura 4.2-e);

- Migração da margem gengival - subtração da medida de MG póssutura e MG de 1 a 12 meses nos sítios $M, V, L$ e D, com valor negativo para migração coronal (Figura 4.2 - f) e valor positivo, para migração apical da margem gengival. 


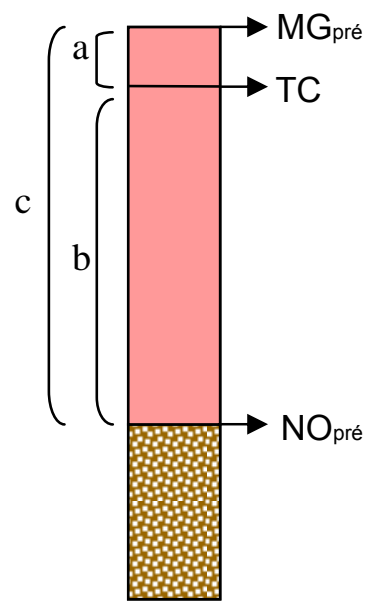

FASE PRÉ-CIRÚRGICA

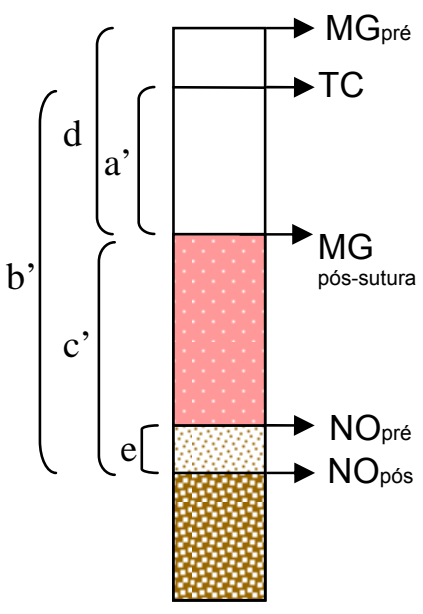

FASE CIRÚRGICA

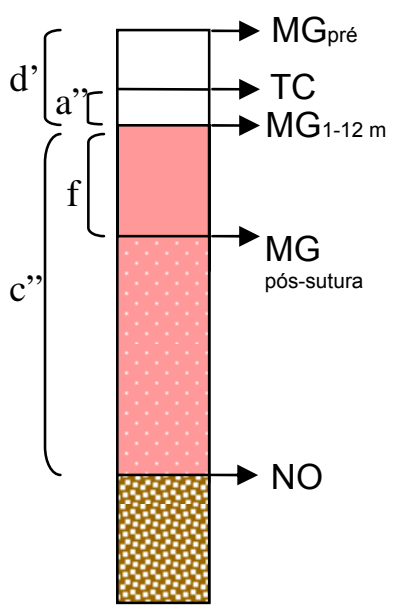

FASE de CONTROLE (1 a 12 meses)

FIGURA 4.2 - Desenho esquemático das medidas clínicas realizadas na fase pré-cirúrgica, cirúrgica e de controle (1 a 12 meses): a, a' e a" - distância do término cervical (TC) em relação à margem gengival (MG); b e b' - distância entre término cervical e crista óssea; c, c' e c" - tecido gengival supra-ósseo; d e d' - aumento de coroa clínica aparente obtido; e - ressecção óssea; f migração da margem gengival. (NO - nível ósseo; NOpré - nível ósseo préosteotomia; NOpós - nível ósseo pós-osteotomia; MGpré - margem gengival pré-

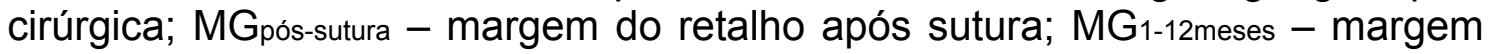
gengival após 1-12 meses da cirurgia).

Outros parâmetros clínicos também foram avaliados, como:

- Espessura gengival (EG) - medida realizada com uma agulha gengival anestésica introduzida perpendicularmente no nível da profundidade de sondagem vestibular até tocar a superfície dentária $^{44}$ de cada pré-molar, previamente à cirurgia (Figura 4.3A). Após colocar o cursor endodôntico em contato com a gengiva, a medida obtida com a agulha anestésica foi mensurada com paquímetro digital Starrett ${ }^{\circledR}$ (Figura 4.3-B), da mesma forma como descrita para as medidas obtidas com sonda milimetrada. Um valor $\leq 1,5 \mathrm{~mm}$ foi considerado como gengiva espessa e $>1,5 \mathrm{~mm}$, como gengiva fina ${ }^{14}$. A anestesia foi realizada distante da margem gengival do dente a ser tratado para evitar qualquer 
alteração volumétrica decorrente da quantidade de anestésico injetado ou da vasoconstricção local.

- Distância inter-radicular (DI) - medida da menor distância interradicular entre pré-molar a ser tratado e dente adjacente, realizada com paquímetro digital Starrett $^{\circledR}$, em molde de silicona de condensação Optosil ${ }^{\circledR}$ (Heraeus Kulzer $\mathrm{GmbH}$ \& Co. KG, Germany) obtido antes e após osteotomia (Figura 4.4);

- Exposição óssea (EO) - avaliação da exposição da crista óssea proximal após sutura do retalho (Figura 4.5);

- Placa bacteriana (PB) - avaliação dicotômica da presença ou ausência de placa bacteriana após evidenciação com verde de malaquita a $1 \%$ nos sítios $M, V, L$ e $D$. À ausência de placa foi atribuída escore 0 e à sua presença, escore 1;

- Índice de sangramento gengival (IS) - avaliação dicotômica do sangramento gengival ocorrido dentro de 10 segundos após sondagem nos sítios $\mathrm{Da}, \mathrm{M}, \mathrm{V}, \mathrm{L}, \mathrm{D}$ e $\mathrm{Ma}$, atribuindo-se escore 0 para ausência de sangramento e escore 1, para sua presença ${ }^{2}$;

- Papila gengival (PG) - análise visual, após secagem com ar da seringa tríplice, em relação a:

I. Forma: escore 0 para vértice da papila gengival com forma côncava (Figura 4.6-A) e escore 1 para forma plana (Figura 4.6-B) e convexa (Figura 4.6-C);

II. "Dobra": escore 0 para ausência e escore 1 para presença de "dobra" (seta) na papila gengival (Figura 4.7);

III. Aspecto: escore 0 para ausência (Figura 4.8-A) e escore 1 para presença de aspecto casca de laranja (stippling) (Figura 4.8-B). 

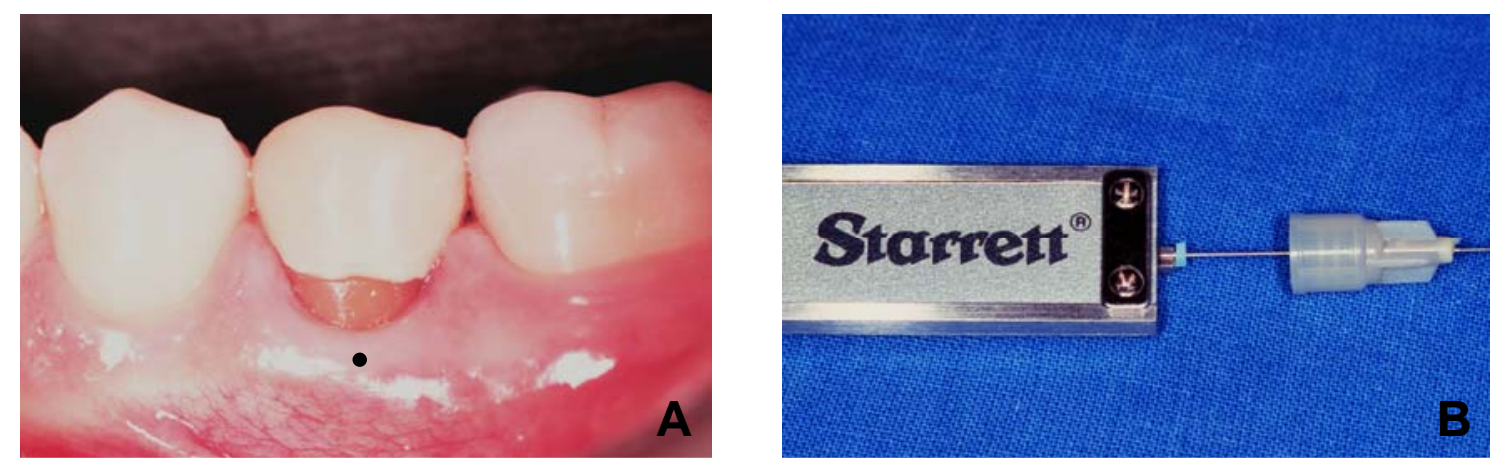

FIGURA 4.3 - (A) Medida da espessura gengival no centro da face vestibular do segundo pré-molar $(\bullet)$ com agulha anestésica e cursor endodôntico foi obtida no nível da profundidade do sulco gengival. (B) A mensuração dessa medida foi realizada com paquímetro digital Starrett ${ }^{\circledR}$.

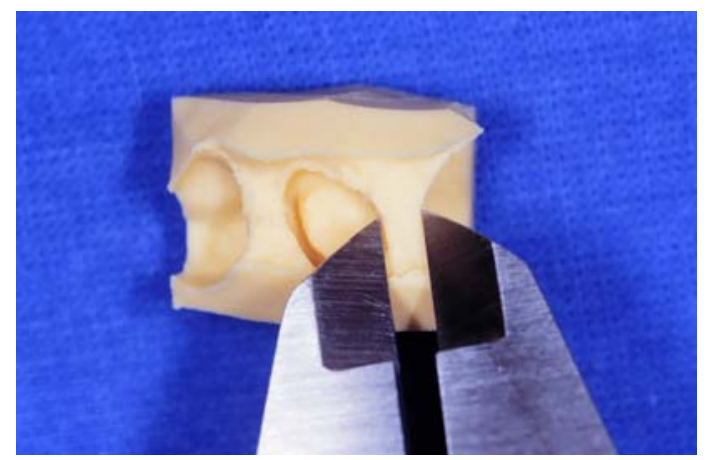

FIGURA 4.4 - Medida da menor distância inter-radicular entre pré-molar e dente adjacente com paquímetro digital Starrett ${ }^{\circledR}$ em molde de silicona de condensação Optosil ${ }^{\circledR}$.

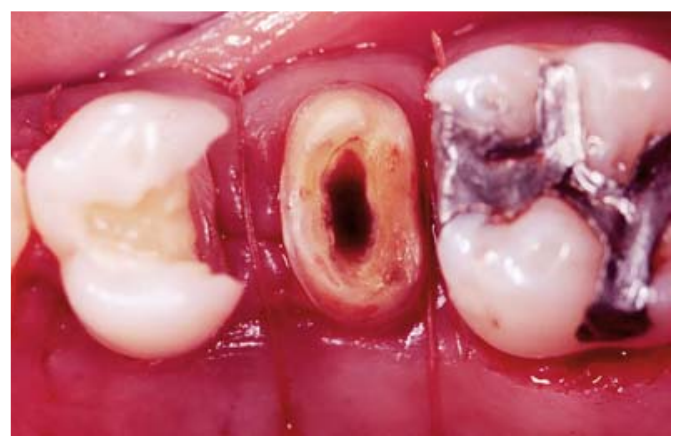

FIGURA 4.5 - Numa vista oclusal, observa-se coaptação das margens dos retalhos vestibular e lingual no sítio mesial e exposição óssea no sítio distal do segundo pré-molar. 


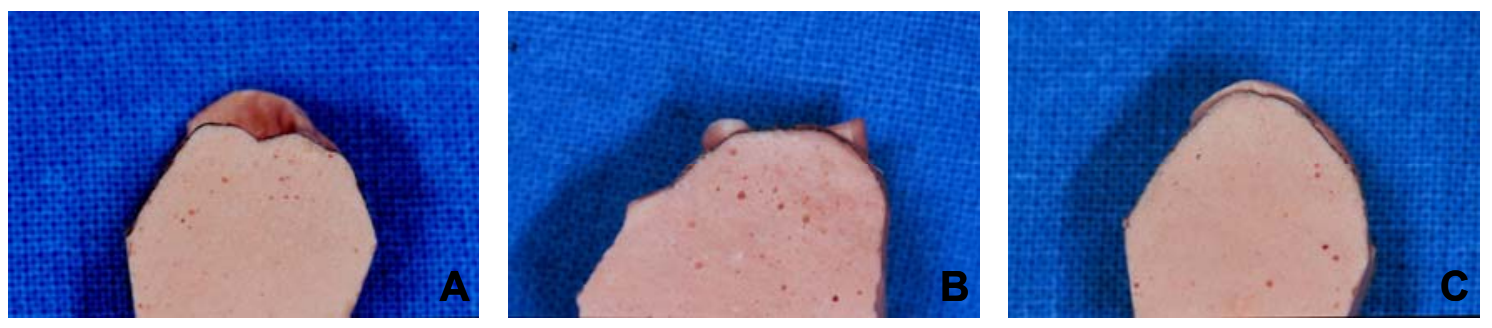

FIGURA 4.6 - Ilustração da forma da papila gengival em modelo de gesso: numa vista proximal da papila, nota-se sua forma côncava $(\mathbf{A})$, plana (B) e convexa (C).
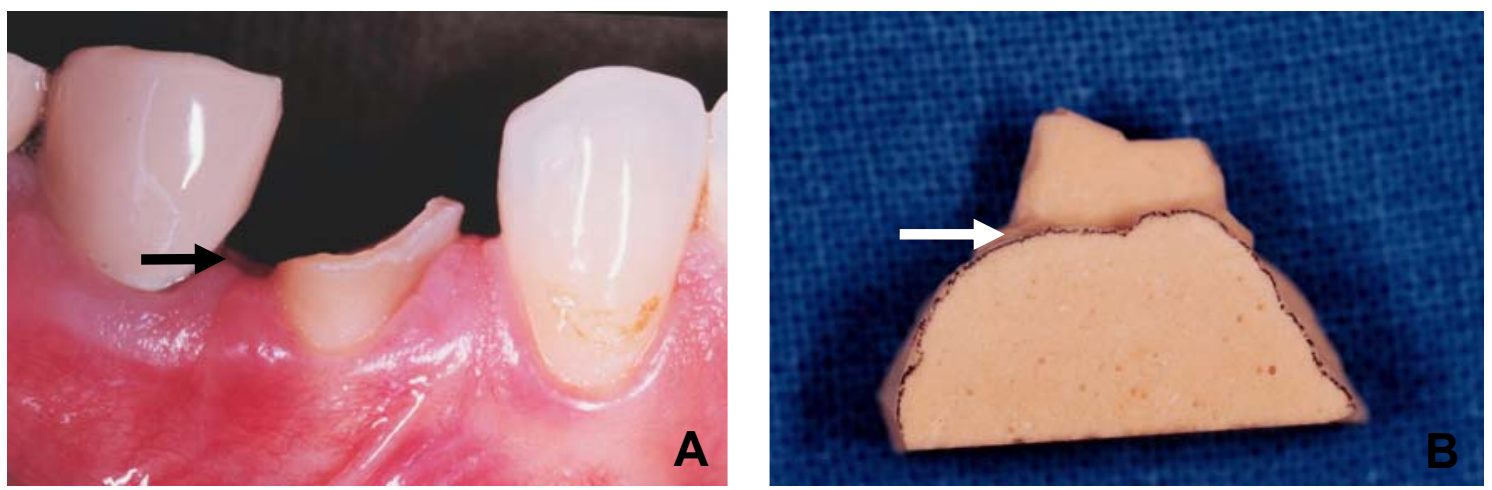

FIGURA 4.7 - "Dobra" na papila gengival: numa vista vestibular da área do primeiro pré-molar, a papila gengival mesial apresenta-se com contorno biselado, enquanto a papila distal, com presença de "dobra" (seta) (A). No modelo de gesso, a "dobra" pode ser analisada no sentido vestíbulo-lingual como um achatamento da porção vestibular da papila gengival(B).
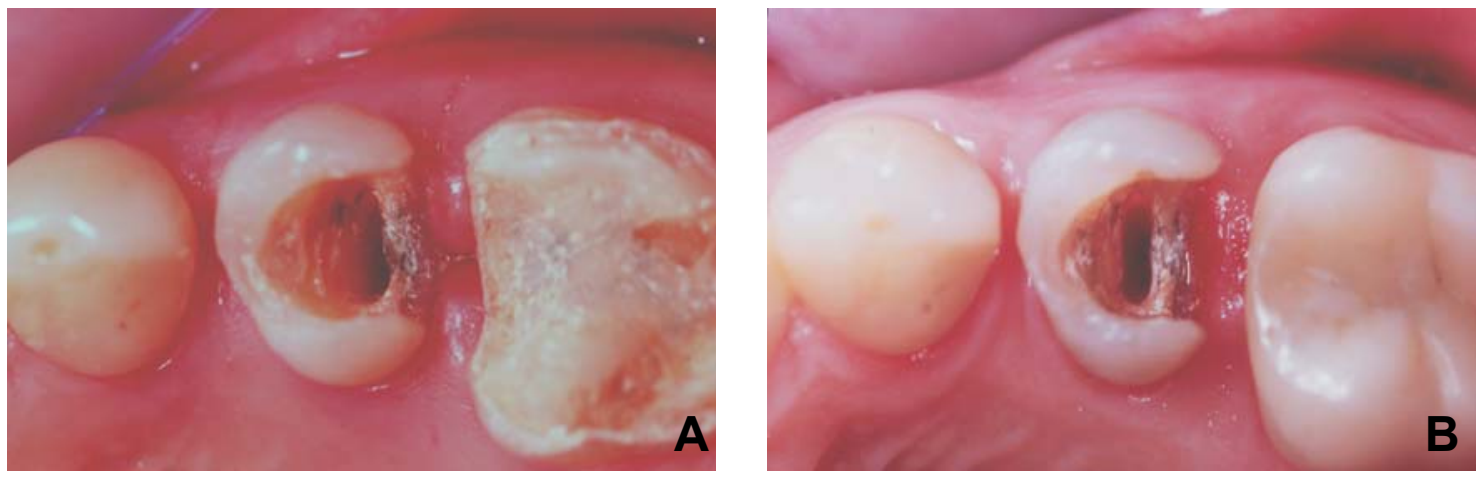

FIGURA 4.8 - Aspecto da papila gengival: numa vista oclusal da região do segundo pré-molar, a papila distal apresenta-se com aspecto liso e brilhante (A) e após 12meses, observa-se com aspecto casca de laranja (stippling) (B). 

Os parâmetros clínicos $\mathrm{PB}_{0}, \mathrm{MG}_{0}, \quad \mathrm{NIR}, \mathrm{R}_{0}, \quad \mathrm{JMG}_{0}$ e $\mathrm{PG}_{0}$ e radiografias $\mathrm{RX}_{0}$ obtidos na fase pré-cirúrgica ou cirúrgica (pós-osteotomia e pós-sutura) foram considerados como medidas iniciais (Tabela 4.1).

TABELA 4.1 - Seqüência dos parâmetros clínicos e das radiografias (RX) na fase pré-cirúrgica, cirúrgica (pré-osteotomia, pós-osteotomia e pós-sutura) e de controle pós-operatório (1, 2, 3, 4, 5, 6 e 12 meses).

\begin{tabular}{|c|c|c|c|c|c|c|c|c|c|c|}
\hline \multirow{2}{*}{$\begin{array}{c}\text { Fase } \\
\text { Pré- } \\
\text { cirúrgica }\end{array}$} & \multicolumn{3}{|c|}{$\begin{array}{c}\text { Fase } \\
\text { Cirúrgica }\end{array}$} & \multicolumn{7}{|c|}{$\begin{array}{c}\text { Fase de } \\
\text { Controle pós-operatório }\end{array}$} \\
\hline & $\begin{array}{c}\text { Pré- } \\
\text { osteotomia }\end{array}$ & $\begin{array}{c}\text { Pós- } \\
\text { osteotomia }\end{array}$ & $\begin{array}{l}\text { Pós- } \\
\text { sutura }\end{array}$ & $1 \mathrm{~m}$ & $2 \mathrm{~m}$ & $3 \mathrm{~m}$ & $4 \mathrm{~m}$ & $5 \mathrm{~m}$ & $6 \mathrm{~m}$ & $12 \mathrm{~m}$ \\
\hline $\mathrm{PB}_{0}$ & & & & $\mathrm{~PB}_{1}$ & $\mathrm{~PB}_{2}$ & $\mathrm{~PB}_{3}$ & $\mathrm{~PB}_{4}$ & $\mathrm{~PB}_{5}$ & $\mathrm{~PB}_{6}$ & $\mathrm{~PB}_{12}$ \\
\hline MG & & & $\mathrm{MG}_{0}$ & $\mathrm{MG}_{1}$ & $\mathrm{MG}_{2}$ & $\mathrm{MG}_{3}$ & $\mathrm{MG}_{4}$ & $\mathrm{MG}_{5}$ & $\mathrm{MG}_{6}$ & $\mathrm{MG}_{12}$ \\
\hline $\mathrm{NIR}_{0}$ & & & & & $\mathrm{NIR}_{2}$ & $\mathrm{NIR}_{3}$ & $\mathrm{NIR}_{4}$ & $\mathrm{NIR}_{5}$ & $\mathrm{NIR}_{6}$ & $\mathrm{NIR}_{12}$ \\
\hline$I_{0}$ & & & & & $\mathrm{IS}_{2}$ & $\mathrm{IS}_{3}$ & $\mathrm{IS}_{4}$ & $\mathrm{IS}_{5}$ & $\mathrm{IS}_{6}$ & $\mathrm{IS}_{12}$ \\
\hline JMG & & & $\mathrm{JMG}_{0}$ & $\mathrm{JMG}_{1}$ & $\mathrm{JMG}_{2}$ & $\mathrm{JMG}_{3}$ & $\mathrm{JMG}_{4}$ & $\mathrm{JMG}_{5}$ & $\mathrm{JMG}_{6}$ & $\mathrm{JMG}_{12}$ \\
\hline $\mathrm{PG}_{0}$ & & & & $\mathrm{PG}_{1}$ & $\mathrm{PG}_{2}$ & $\mathrm{PG}_{3}$ & $\mathrm{PG}_{4}$ & $\mathrm{PG}_{5}$ & $\mathrm{PG}_{6}$ & $\mathrm{PG}_{12}$ \\
\hline \multicolumn{11}{|l|}{ EG } \\
\hline & NO & NO & & & & & & & & \\
\hline & DI & DI & & & & & & & & \\
\hline \multicolumn{11}{|c|}{ TC } \\
\hline & & & EO & & & & & & & \\
\hline & $R X$ & $\mathrm{RX}_{0}$ & & & $\mathrm{RX}_{1}$ & $\mathrm{RX}_{2}$ & & & $\mathrm{RX}_{3}$ & $\mathrm{RX}_{4}$ \\
\hline
\end{tabular}

Parâmetros clínicos de placa bacteriana (PB), margem gengival (MG), nível de inserção relativo (NIR), índice de sangramento gengival (IS), junção mucogengival (JMG), papila gengival (PG), espessura gengival (EG), nível ósseo (NO), distância inter-radicular (DI), término cervical do preparo (TC) e exposição óssea proximal (EO).
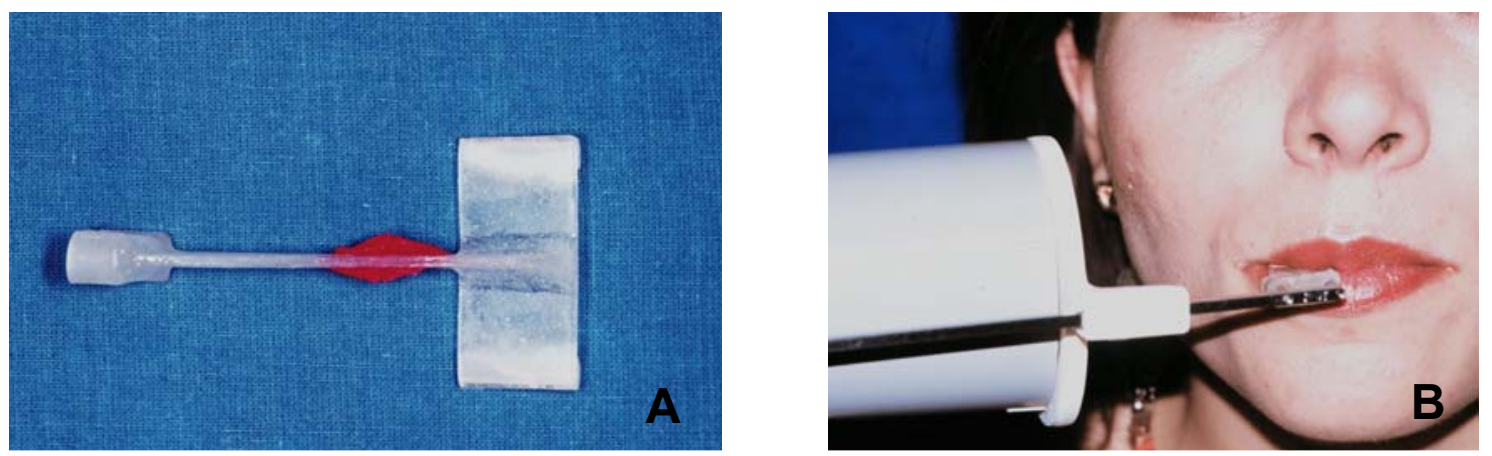

FIGURA 4.9 - Avaliação radiográfica. Posicionador radiográfico interproximal duplicado em resina acrílica incolor, com registro oclusal dos dentes em resina Duralay (A), foi acoplado à haste indicadora e anel localizador para tomada radiográfica interproximal padronizada $(\mathbf{B})$. 



\section{5 - Avaliação radiográfica}

\subsection{1 - Confecção do posicionador radiográfico individuai}

A utilização de posicionadores radiográficos individuais foi baseada na metodologia descrita por TABA JÚNIOR ${ }^{62}$ (1995), com objetivo de permitir o posicionamento do filme radiográfico paralelo ao dente; confeccionar registro para padronização da área a ser radiografada; obter fidelidade na padronização; permitir durabilidade para tomadas radiográficas seqüenciais; preservar qualidade da imagem e facilitar aplicação clínica.

Após seleção do posicionador Bite-wing (interproximal) Rinn ${ }^{\circledR}$ (Rinn Corporation, Illinois, USA) ${ }^{19}$ para técnica radiográfica interproximal, um molde de silicone industrial foi confeccionado para a sua duplicação em resina acrílica incolor ativada quimicamente Jet Clássico $^{\circledR}$ (Artigos Odontológicos Clássico Ltda, São Paulo, Brasil) (Figura 4.9-A). Para cada área a ser radiografada, foi confeccionado um registro oclusal dos dentes superiores e inferiores em resina acrílica Duralay ${ }^{\circledR}$ (Reliance Dental Mfg Co, Worth, USA) no posicionador acrílico. Este registro foi realizado em sessão prévia à da tomada radiográfica para garantir a completa polimerização da resina e evitar distorções nas tomadas subseqüentes $^{62}$. Cada posicionador foi acondicionado no mesmo pote plástico utilizado para a placa oclusal.

\subsection{2 - Tomadas radiográficas padronizadas}

Para aplicação clínica, cada posicionador foi ajustado à haste indicadora e ao anel localizador de cilindro Bite-wing Rinn ${ }^{\circledR}$ (Figura 4.9-B). Em todas as tomadas radiográficas interproximais foi utilizado o mesmo aparelho Dabi-Atlante $70 \mathrm{KV}$ de $8 \mathrm{~mA}$, com 0,7 segundo de tempo de exposição e filme Kodak $^{\circledR}$ Ektaspeed (Eastman Kodak Co, Rochester, USA), do mesmo lote, para padronização das imagens radiográficas. 


\subsection{3 - Processamento das radiografias}

Os filmes radiográficos foram revelados com processadora automática de radiografias ${ }^{52}$ Perio-pro II (Air Technique Inc., New York, USA.), efetuando a troca semanal da solução reveladora e fixadora.

\subsection{4 - Análise das imagens radiográficas}

Todas as radiografias de um mesmo pré-molar foram posicionadas em um negatoscópio, com máscara de cartolina preta, para permitir passagem de luz somente através das radiografias. O ambiente foi mantido em penumbra, evitando-se desta forma eventual interferência nas avaliações radiográficas ${ }^{3}$. 0 parâmetro radiográfico analisado foi ausência (escore 0) e presença (escore1) da lâmina dura intacta nas cristas ósseas M e D após ressecção óssea. Como critério de avaliação, a repetição da interpretação foi realizada 2 meses após a primeira, sempre pelo mesmo observador ${ }^{3}$ (Examinador 1 ).

Posteriormente, a seqüência radiográfica de cada paciente foi posicionada sobre um negatoscópio de luz contínua MEDALight ${ }^{\circledR}$ LP-400 e fotografada com câmera digital Coolpix 5700 Nikon $^{\circledR}$ de 5 mega pixels. Para padronização das fotografias, as seqüências radiográficas de todos os pacientes foram realizadas no mesmo período, com a câmera fotográfica fixada numa estativa, perpendicularmente ao negatoscópio, a uma mesma distância de foco, que permitiu o enquadramento das 6 radiografias. As imagens foram abertas no programa Image ${ }^{\circledR}$ (NIH - EUA), em um computador que opera com plataforma Windows, com monitor de 17 polegadas e tela plana. A sala foi escurecida durante análise das radiografias para melhorar a visualização. Cada imagem foi convertida para 8 bits e calibrada a partir da medida da radiografia periapical (40mm). Em seguida, a imagem foi ampliada duas vezes na tela do monitor $^{56}$ para realizar medidas lineares entre término cervical do preparo e nível da crista óssea M e D de cada pré-molar. Para obtenção dessas medidas, o término cervical na imagem radiográfica foi definido como o ponto de intersecção entre parede cervical do preparo e superfície externa do dente, e o 
nível da crista óssea, como aquele ponto mais coronal do osso, com largura uniforme do espaço do ligamento periodontal. O programa forneceu os valores para cada medida. As medidas foram realizadas pelo mesmo examinador e repetidas após 15 dias $^{56}$; a média entre as duas medidas foi tomada como valor.

Como o término cervical foi mantido no mesmo nível em todas as radiografias, uma análise comparativa entre medidas lineares obtidas na imagem pós-osteotomia (medida inicial), pré-osteotomia e de controle pósoperatório (Tabela 4.1) possibilitou detectar alterações no nível ósseo M e D.

\section{6 - Técnica cirúrgica}

Todas as técnicas cirúrgicas foram executadas pelo mesmo profissional especializado (Examinador 1). Os procedimentos cirúrgicos ressectivos (Figura 4.10-a a 4.10-f) foram realizados de um a dois meses depois do preparo inicial ${ }^{49}$. Após anti-sepsia intrabucal com bochecho de solução de gluconato de clorexidina 0,12\% Periogard ${ }^{\circledR}$ (Colgate-Palmolive Ind. Com. Ltda, São Bernardo do Campo, São Paulo), por 1 minuto, foi realizada anestesia por bloqueio regional ou infiltrativa com anestésico Scandicaíne ${ }^{\circledR} 2 \%$ com nor-adrenalina (Septodont, DFL, Rio de Janeiro, Brasil). Uma incisão em bisel interno foi executada nas faces livres do pré-molar a ser tratado, num nível correspondente ao aumento de coroa clínica aparente desejado. Essa incisão foi finalizada dentro do sulco gengival nas faces proximais, com preservação dos contornos das papilas gengivais ${ }^{45}$. Para obter harmonia da nova margem gengival com as áreas adjacentes, as incisões foram estendidas $\mathrm{um}^{49}$ ou dois dentes para mesial e distal. Após remoção do "colar" de tecido gengival, rebatimento de um retalho total vestibular e lingual foi realizada para expor a crista óssea alveolar ${ }^{9,18}$ (Figura 4.10-c). Quando necessário, o término cervical foi definido nesta etapa para servir como ponto de referência fixo para ressecção óssea e para obtenção de outras medidas clínicas ${ }^{61}$. A quantidade de ressecção óssea foi suficiente para obter uma distância mínima de $3 \mathrm{~mm}$ entre término cervical e crista óssea ${ }^{29}$. A osteotomia/osteoplastia foi realizada com instrumentos manuais e/ou rotatórios ${ }^{35}$ nas faces proximais e/ou livres, 
reproduzindo o arco côncavo da crista alveolar (Figura 4.10-d). Subseqüentemente, as superfícies radiculares supra-ósseas foram raspadas e alisadas para remoção de possíveis remanescentes de inserção de fibras de tecido conjuntivo no cemento $^{18,49}$. O retalho foi posicionado e imobilizado aproximadamente $2 \mathrm{~mm}$ coronal à crista óssea, por meio de sutura com fio de sutura Vicryl 6-0 (Ethicon ${ }^{\circledR}$, Johnson \& Johnson, Brasil), para evitar exposição da crista óssea proximal (Figura 4.10-e e 4.10-f). O retalho foi pressionado com gaze umedecida em soro fisiológico por três minutos ${ }^{18}$. Não foi utilizado cimento cirúrgico sobre a área.

A medicação pós-cirúrgica compreendeu a prescrição de antiinflamatório não esteroidal Dipirona, 35 gotas a cada 6 horas, para promover efeito analgésico, e bochecho com solução de gluconato de clorexidina a $0,12 \%$, duas vezes ao dia, durante as duas primeiras semanas ${ }^{18,35}$. Adicionalmente, todos os pacientes receberam orientação quanto aos demais cuidados pós-operatórios, uso cuidadoso do fio dental e escovação delicada sobre a área operada durante a primeira semana pós-operatória. As suturas foram removidas após um período que variou de sete a dez dias da cirurgia $^{18}$.

\section{7 - Controle pós-operatório}

A partir do molde transcirúrgico, foi obtido um modelo em gesso para confecção de novas coroas provisórias. As mesmas foram adaptadas ao término cervical e cimentadas com cimento à base de hidróxido de cálcio Dycal $^{\circledR}$ (Dentsply Ind. Com. Ltda, Petrópolis, São Paulo) ou de fosfato de zinco SSWhite $^{\circledR}$ (SSWhite Artigos Dentários Ltda, Rio de Janeiro, Brasil) com vaselina sólida branca Rioquímica ${ }^{\circledR}$ (Ind. Farmacêutica Rioquímica, São José do Rio Preto, Brasil), duas semanas após a cirurgia.

O controle profissional das áreas tratadas cirurgicamente foi executado semanalmente no primeiro mês, e em seguida, realizado mensalmente ${ }^{74}$ até se completarem seis meses. 

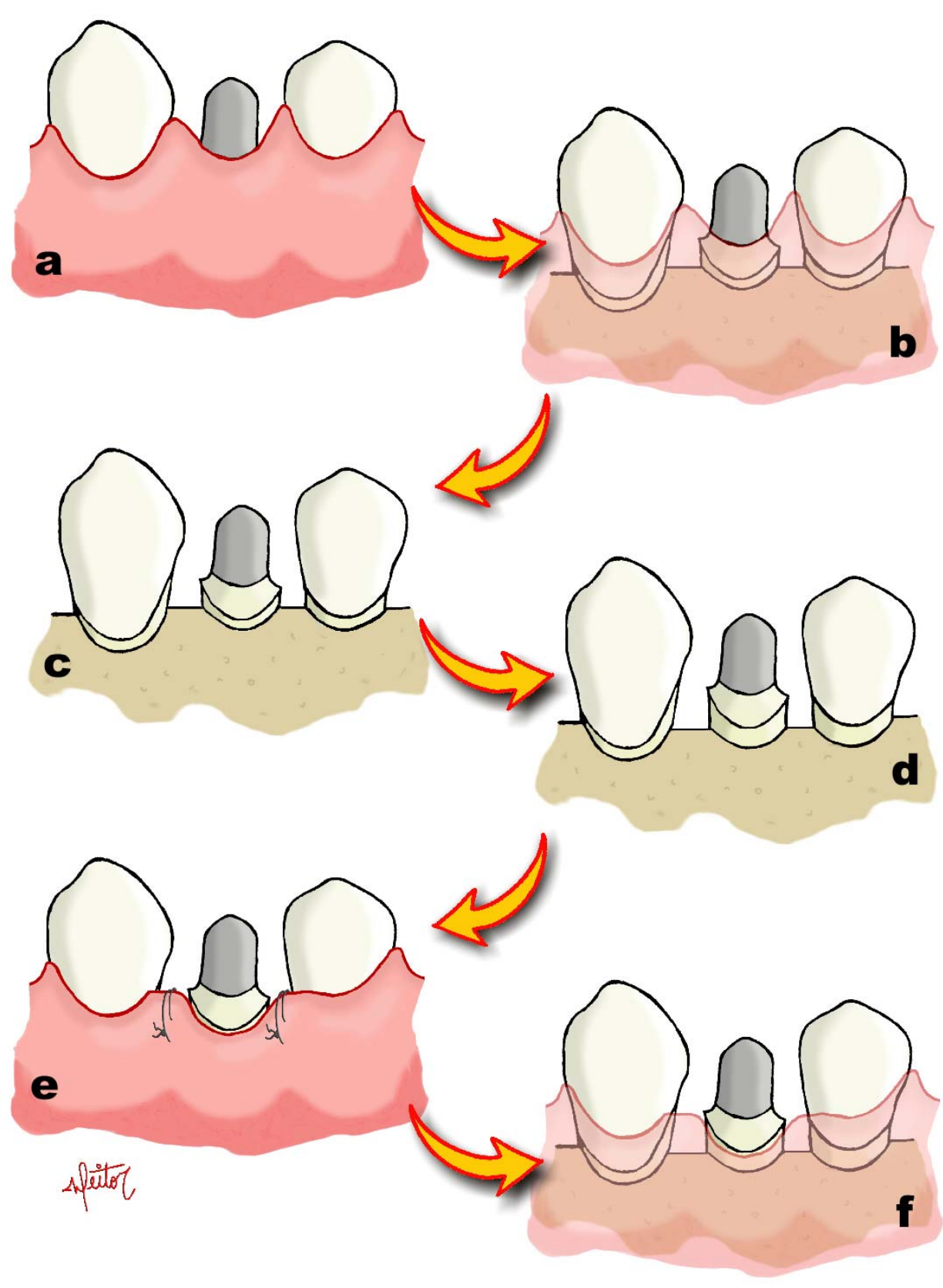

FIGURA 4.10 - Desenho esquemático da técnica cirúrgica de aumento de coroa. Término cervical do preparo para coroa total do $1^{\circ}$ pré-molar localizado subgengival (a), numa distância $<2 \mathrm{~mm}$ até crista óssea alveolar (b). Rebatimento do retalho total vestibular e lingual, a partir de incisão intrasulcular e/ou em bisel interno, permite acesso à crista óssea e confirmação da invasão do espaço da distância biológica (c). Realização de osteotomia/osteoplastia para obter uma distância mínima de $3 \mathrm{~mm}$ entre término cervical e crista alveolar, com reprodução do arco côncavo num nível mais apical (d). Retalhos imobilizados por meio de suturas (e) e posicionados coronal à crista óssea e apical ao término cervical (f). 
Em cada consulta foi realizada a evidenciação de placa com solução de verde de malaquita a 1\%, reforço às instruções de higiene bucal, limpeza mecânica da superfície dentária supra e subgengival e recimentação das coroas provisórias. Quando necessário, foi realizada nova raspagem manual com curetas mini-five. O uso de escovas interdentais e unitufo foi indicado de acordo com a capacidade de cada paciente em manter a área livre de placa bacteriana.

\section{8 - Reavaliações}

Após remoção das coroas provisórias, novas avaliações clínicas de PB, MG, JMG e PG foram realizadas em todos os pacientes após 1, 2, 3, 4, 5, 6 e 12 meses (Tabela 4.1). As medidas de NIR e IS foram obtidas somente a partir do segundo mês.As radiografias interproximais padronizadas foram realizadas apenas nos períodos de 2, 3, 6 e 12 meses pós-operatório (Tabela 4.1), dentro dos mesmos critérios empregados na tomada inicial.

A documentação fotográfica pós-cirúrgica foi realizada em todos os períodos.

\section{9 - Análise estatística}

Após obtenção da média e desvio padrão dos parâmetros clínicos (MG, NIR, JMG, MC, PS, TGS, quantidade de migração da margem gengival e aumento de coroa clínica aparente) e radiográficos (nível da crista óssea proximal), Análise de Variância (ANOVA) para medidas repetidas foi utilizada para indicar diferenças entre medidas. Diante das diferenças de significância estatística, o Teste de Tukey foi empregado para indicar entre quais períodos as diferenças foram significantes. Para os parâmetros de PB, IS e PG, diferenças significantes foram verificadas pelo Teste de McNemar. O Teste de Correlação de Pearson foi utilizado para avaliar correlações entre parâmetros clínicos. Para todas as análises, o nível de significância adotado foi de 0,05. 
RESULTADOS 



\section{RESULTADOS}

Durante a fase de seleção da amostra desta pesquisa foram examinados 84 pacientes. A amostra final consistiu de 23 pacientes, 7 homens e 16 mulheres, com idade entre 20 e 45 anos (média de 32,5 anos). No total foram selecionados 30 dentes pré-molares, 25 superiores e 5 inferiores, sendo 25 pré-molares com preparo dentário para coroa protética e 5 para restauração, com necessidade de cirurgia de aumento de coroa para melhorar retenção da coroa protética e para restabelecer espaço para distância biológica (Tabela 5.1 e 5.2). Sete pacientes apresentaram dois pré-molares cada um.

Não foram observadas complicações periodontais pós-operatórias. Durante 6 meses, 29 dentes pré-molares (22 pacientes) foram examinados em todas as consultas, e aos 12 meses, 28 dentes pré-molares (21 pacientes). Um posicionador radiográfico individual apresentou distorção no primeiro mês e uma placa oclusal foi perdida no terceiro mês. Aos 12 meses, uma placa oclusal e um posicionador radiográfico de um mesmo pré-molar não ajustaram devido à movimentação dentária. 
TABELA 5.1 - Distribuição do número de dentes (n) pré-molares 14, 15, 24, 25 , 34, 35, 44 e 45 de acordo com a causa da indicação cirúrgica (coroa clínica curta ou invasão do espaço da distância biológica pela cárie ou fratura dentária ou término cervical pré-existente) e o tipo de preparo dentário (coroa protética ou restauração).

\begin{tabular}{|c|c|c|c|c|c|c|c|c|c|}
\hline \multirow{2}{*}{$\begin{array}{l}\text { Pré- } \\
\text { molar }\end{array}$} & \multicolumn{2}{|c|}{$\begin{array}{c}\text { Coroa clínica } \\
\text { curta } \\
n=2\end{array}$} & \multicolumn{2}{|c|}{$\begin{array}{l}\text { Cárie } \\
\mathrm{n}=18\end{array}$} & \multicolumn{2}{|c|}{$\begin{array}{l}\text { Fratura dentária } \\
\qquad \mathrm{n}=9\end{array}$} & \multicolumn{2}{|c|}{$\begin{array}{l}\text { Término cervical } \\
\text { pré-existente } \\
n=1\end{array}$} & \multirow{2}{*}{$\begin{array}{l}\text { Total } \\
\mathrm{n}=30\end{array}$} \\
\hline & $\begin{array}{l}\text { Coroa } \\
\text { protética }\end{array}$ & Restauração & $\begin{array}{l}\text { Coroa } \\
\text { protética }\end{array}$ & Restauração & $\begin{array}{l}\text { Coroa } \\
\text { protética }\end{array}$ & Restauração & $\begin{array}{l}\text { Coroa } \\
\text { protética }\end{array}$ & Restauração & \\
\hline 14 & & & 2 & 2 & 4 & & & & 8 \\
\hline 15 & & & 4 & 1 & & & & & 5 \\
\hline 24 & 1 & & 3 & 1 & & & & & 5 \\
\hline 25 & & & 2 & & 4 & & 1 & & 7 \\
\hline \multicolumn{10}{|l|}{34} \\
\hline 35 & 1 & & 1 & & & & & & 2 \\
\hline 44 & & & 1 & & & & & & 1 \\
\hline 45 & & & & 1 & 1 & & & & 2 \\
\hline
\end{tabular}

TABELA 5.2 - Distribuição do número de sítios (n) mesial, vestibular, lingual e distal com invasão do espaço da distância biológica (distância $\leq 2,0 \mathrm{~mm}$ entre término cervical e crista óssea alveolar).

\begin{tabular}{ccccc}
\hline $\begin{array}{c}\text { Distância entre término } \\
\text { cervical e crista óssea }\end{array}$ & $\begin{array}{c}\text { Mesial } \\
\mathrm{n}=13\end{array}$ & $\begin{array}{c}\text { Vestibular } \\
\mathrm{n}=9\end{array}$ & $\begin{array}{c}\text { Lingual } \\
\mathrm{n}=12\end{array}$ & $\begin{array}{c}\text { Distal } \\
\mathrm{n}=21\end{array}$ \\
\hline $\mathbf{0 m m}$ & & & & 1 \\
$\mathbf{0 , 5 \mathrm { mm }}$ & 2 & & 1 & 1 \\
$\mathbf{1 , 0 \mathrm { mm }}$ & 4 & 2 & 2 & 3 \\
$\mathbf{1 , 5 \mathrm { mm }}$ & 3 & 1 & 3 & 5 \\
$\mathbf{2 , 0 \mathrm { mm }}$ & 4 & 6 & 6 & 11 \\
\hline
\end{tabular}




\section{1 - Avaliação clínica}

TABELA 5.3 - Distribuição dos sítios mesial, vestibular, lingual e distal com placa bacteriana na fase pré-cirúrgica e de controle pós-operatório de 1, 2, 3, 4 , 5,6 e 12 meses, em porcentagem.

\begin{tabular}{lcccc}
\hline Fase & Mesial & Vestibular & Lingual & Distal \\
\hline Pré-cirúrgica & 86,7 & 36,7 & 66,7 & 86,7 \\
$\mathbf{1}$ mês & $46,7^{*}$ & 10,0 & 70,0 & $43,3^{*}$ \\
$\mathbf{2}$ meses & $58,6^{*}$ & 27,6 & 79,3 & $58,6^{*}$ \\
$\mathbf{3}$ meses & $37,9^{*}$ & $10,3^{*}$ & 62,1 & $48,3^{*}$ \\
$\mathbf{4}$ meses & $34,5^{*}$ & 10,3 & 58,6 & $27,6^{*}$ \\
$\mathbf{5}$ meses & $31,0^{*}$ & $3,4^{*}$ & 75,9 & $55,2^{*}$ \\
$\mathbf{6}$ meses & $31,0^{*}$ & $0^{*}$ & 69,0 & $44,8^{*}$ \\
$\mathbf{1 2}$ meses & $37,0^{*}$ & $3,7^{*}$ & 74,1 & $44,4^{*}$ \\
\hline
\end{tabular}

TABELA 5.4 - Distribuição dos sítios distal adjacente, mesial, vestibular, lingual, distal e mesial adjacente com sangramento gengival na fase pré-cirúrgica e de controle pós-operatório de 2, 3, 4, 5, 6 e 12 meses, em porcentagem.

\begin{tabular}{lrrrrrr}
\hline Fase & $\begin{array}{c}\text { Distal } \\
\text { adjacente }\end{array}$ & Mesial & Vestibular & Lingual & Distal $\begin{array}{c}\text { Mesial } \\
\text { adjacente }\end{array}$ \\
\hline Pré-cirúrgica & 19,2 & 46,2 & 16,7 & 36,7 & 72,4 & 46,4 \\
$\mathbf{2}$ meses & 8,3 & 16,7 & 6,9 & 41,4 & $42,9^{*}$ & 25,9 \\
$\mathbf{3}$ meses & 4,3 & 13,0 & $0^{*}$ & 14,3 & $29,6^{*}$ & $15,4^{*}$ \\
$\mathbf{4}$ meses & 4,3 & 17,4 & 3,6 & 14,3 & $11,1^{*}$ & $11,5^{*}$ \\
$\mathbf{5}$ meses & 8,7 & $4,3^{*}$ & $0^{*}$ & 17,9 & $14,8^{*}$ & $7,7^{*}$ \\
$\mathbf{6}$ meses & 4,3 & $4,3^{*}$ & 7,1 & 14,3 & $14,8^{*}$ & $3,8^{*}$ \\
$\mathbf{1 2}$ meses & $0^{*}$ & $4,8^{*}$ & $0^{*}$ & 19,2 & $12,5^{*}$ & $4,2^{*}$ \\
\hline
\end{tabular}

* Teste McNemar: estatisticamente significante em relação à fase pré-cirúrgica $(p<0,05)$ 
TABELA 5.5 - Valores médios e desvios padrão das medidas de profundidade de sondagem nos sítios distal adjacente, mesial, vestibular, lingual, distal e mesial adjacente na fase pré-cirúrgica e de controle pós-operatório de 2, 3, 4, 5 , 6 e 12 meses, em milímetros, e resultados da ANOVA e Teste de Tukey.

\begin{tabular}{ccccccc}
\hline Fase & $\begin{array}{c}\text { Distal } \\
\text { adjacente }\end{array}$ & Mesial & Vestibular & Lingual & Distal & $\begin{array}{c}\text { Mesial } \\
\text { adjacente }\end{array}$ \\
\hline Pré-cirúrgica & $2,19 \pm 0,75$ & $2,12 \pm 0,67$ & $1,72 \pm 0,73^{\mathrm{a}}$ & $1,80 \pm 0,61$ & $2,36 \pm 1,17^{\mathrm{a}, \mathrm{b}}$ & $2,46 \pm 0,90$ \\
$\mathbf{2}$ meses & $1,88 \pm 0,66^{\mathrm{ns}}$ & $1,92 \pm 0,62^{\mathrm{ns}}$ & $1,28 \pm 0,56^{\mathrm{b}}$ & $1,75 \pm 0,77^{\mathrm{ns}}$ & $1,93 \pm 0,82^{\mathrm{c}}$ & $2,13 \pm 0,85^{\mathrm{ns}}$ \\
$\mathbf{3}$ meses & $1,86 \pm 0,63^{\mathrm{ns}}$ & $2,00 \pm 0,74^{\mathrm{ns}}$ & $1,33 \pm 0,44^{\mathrm{b}}$ & $1,81 \pm 0,69^{\mathrm{ns}}$ & $2,05 \pm 0,88^{\mathrm{b}, \mathrm{c}}$ & $2,19 \pm 0,87^{\mathrm{ns}}$ \\
$\mathbf{4}$ meses & $1,96 \pm 0,52^{\mathrm{ns}}$ & $2,12 \pm 0,69^{\mathrm{ns}}$ & $1,33 \pm 0,39^{\mathrm{b}}$ & $1,97 \pm 0,56^{\mathrm{ns}}$ & $2,17 \pm 0,78^{\mathrm{b}, \mathrm{c}}$ & $2,17 \pm 0,77^{\mathrm{ns}}$ \\
$\mathbf{5}$ meses & $2,08 \pm 0,53^{\mathrm{ns}}$ & $2,22 \pm 0,61^{\mathrm{ns}}$ & $1,37 \pm 0,40^{\mathrm{b}}$ & $1,91 \pm 0,67^{\mathrm{ns}}$ & $2,31 \pm 0,74^{\mathrm{a}, \mathrm{b}, \mathrm{c}}$ & $2,26 \pm 0,76^{\mathrm{ns}}$ \\
$\mathbf{6}$ meses & $2,06 \pm 0,56^{\mathrm{ns}}$ & $2,31 \pm 0,67^{\mathrm{ns}}$ & $1,45 \pm 0,35^{\mathrm{a}, \mathrm{b}}$ & $2,00 \pm 0,67^{\mathrm{ns}}$ & $2,44 \pm 0,78^{\mathrm{a}, \mathrm{b}}$ & $2,46 \pm 0,85^{\mathrm{ns}}$ \\
$\mathbf{1 2}$ meses & $2,15 \pm 0,71^{\mathrm{ns}}$ & $2,28 \pm 0,55^{\mathrm{ns}}$ & $1,36 \pm 0,55^{\mathrm{b}}$ & $1,97 \pm 0,53^{\mathrm{ns}}$ & $2,71 \pm 0,69^{\mathrm{a}}$ & $2,32 \pm 0,69^{\mathrm{ns}}$ \\
\hline
\end{tabular}

Períodos com a mesma letra não possuem diferenças estatisticamente significantes entre si $(p>0,05)$ ns - estatisticamente não significante $(p>0,05)$

TABELA 5.6 - Valores médios e desvios padrão das medidas de nível de inserção relativo nos sítios distal adjacente, mesial, vestibular, lingual, distal e mesial adjacente na fase pré-cirúrgica e de controle pós-operatório de 2, 3, 4, 5 , 6 e 12 meses, em milímetros, e resultados da ANOVA e Teste de Tukey.

\begin{tabular}{ccccccc}
\hline Fase & $\begin{array}{c}\text { Distal } \\
\text { adjacente }\end{array}$ & Mesial & Vestibular & Lingual & Distal & $\begin{array}{c}\text { Mesial } \\
\text { adjacente }\end{array}$ \\
\hline Pré-cirúrgica & $8,23 \pm 1,05^{\mathrm{c}}$ & $8,18 \pm 0,96^{\mathrm{b}}$ & $9,53 \pm 1,70^{\mathrm{b}}$ & $8,65 \pm 1,06^{\mathrm{b}}$ & $8,53 \pm 0,98^{\mathrm{b}}$ & $8,48 \pm 1,42^{\mathrm{c}}$ \\
$\mathbf{2}$ meses & $9,35 \pm 1,31^{\mathrm{a}}$ & $9,39 \pm 1,30^{\mathrm{a}}$ & $10,64 \pm 1,49^{\mathrm{a}}$ & $10,38 \pm 1,34^{\mathrm{a}}$ & $9,74 \pm 1,16^{\mathrm{a}}$ & $9,89 \pm 1,25^{\mathrm{a}}$ \\
$\mathbf{3}$ meses & $9,19 \pm 1,38^{\mathrm{a}, \mathrm{b}}$ & $9,33 \pm 1,36^{\mathrm{a}}$ & $10,65 \pm 1,66^{\mathrm{a}}$ & $10,30 \pm 1,33^{\mathrm{a}}$ & $9,62 \pm 1,12^{\mathrm{a}}$ & $9,67 \pm 1,17^{\mathrm{a}}$ \\
$\mathbf{4}$ meses & $9,17 \pm 1,26^{\mathrm{a}, \mathrm{b}}$ & $9,32 \pm 1,46^{\mathrm{a}}$ & $10,60 \pm 1,59^{\mathrm{a}}$ & $10,35 \pm 1,32^{\mathrm{a}}$ & $9,67 \pm 1,04^{\mathrm{a}}$ & $9,60 \pm 1,14^{\mathrm{a}, \mathrm{b}}$ \\
$\mathbf{5}$ meses & $9,11 \pm 1,32^{\mathrm{a}, \mathrm{b}}$ & $9,25 \pm 1,45^{\mathrm{a}}$ & $10,56 \pm 1,54^{\mathrm{a}}$ & $10,30 \pm 1,24^{\mathrm{a}}$ & $9,70 \pm 1,01^{\mathrm{a}}$ & $9,58 \pm 1,21^{\mathrm{a}, \mathrm{b}}$ \\
$\mathbf{6}$ meses & $9,01 \pm 1,28^{\mathrm{a}, \mathrm{b}}$ & $9,26 \pm 1,42^{\mathrm{a}}$ & $10,64 \pm 1,53^{\mathrm{a}}$ & $10,36 \pm 1,17^{\mathrm{a}}$ & $9,66 \pm 0,98^{\mathrm{a}}$ & $9,61 \pm 1,11^{\mathrm{a}, \mathrm{b}}$ \\
$\mathbf{1 2}$ meses & $8,70 \pm 1,20^{\mathrm{b}}$ & $8,82 \pm 1,20^{\mathrm{a}}$ & $10,34 \pm 1,40^{\mathrm{a}}$ & $10,05 \pm 1,04^{\mathrm{a}}$ & $9,50 \pm 0,69^{\mathrm{a}}$ & $9,11 \pm 1,11^{\mathrm{b}}$ \\
\hline
\end{tabular}

Períodos com a mesma letra não possuem diferenças estatisticamente significantes entre si $(p>0,05)$ 
TABELA 5.7 - Valores médios e desvios padrão das medidas da distância entre término cervical e crista óssea alveolar nos sítios mesial, vestibular, lingual e distal na fase cirúrgica pré e pós-osteotomia, em milímetros.

\begin{tabular}{lcccc}
\hline Fase cirúrgica & Mesial & Vestibular & Lingual & Distal \\
\hline Pré-osteotomia & $2,03 \pm 0,89$ & $2,62 \pm 1,18$ & $2,32 \pm 0,89$ & $1,87 \pm 0,75$ \\
Pós-osteotomia & $3,03 \pm 0,53$ & $3,95 \pm 0,81$ & $3,51 \pm 0,46$ & $3,04 \pm 0,78$
\end{tabular}

TABELA 5.8 - Distribuição do número de sítios (n) e sua porcentagem (\%) de acordo com a quantidade de ressecção óssea realizada ao redor dos dentes pré-molares.

\begin{tabular}{ccc}
\hline Ressecção óssea & $\mathbf{n}$ & $\%$ \\
\hline $\mathbf{0 m m}$ & 52 & 45,2 \\
$\mathbf{1} \mathbf{m m}$ & 44 & 38,3 \\
$\mathbf{2 m m}$ & 17 & 14,8 \\
$\mathbf{3 m m}$ & 2 & 1,7 \\
\hline
\end{tabular}

TABELA 5.9 - Valores médios e desvios padrão das medidas de ressecção óssea (RO) realizada nos sítios distal adjacente, mesial, vestibular, lingual, distal e mesial adjacente durante a fase cirúrgica, em milímetros.

\begin{tabular}{lcccccc}
\hline & $\begin{array}{c}\text { Distal } \\
\text { adjacente }\end{array}$ & Mesial & Vestibular & Lingual & Distal & $\begin{array}{c}\text { Mesial } \\
\text { adjacente }\end{array}$ \\
\hline RO & $0,86 \pm 0,68$ & $0,99 \pm 0,76$ & $1,20 \pm 0,86$ & $1,11 \pm 0,77$ & $1,17 \pm 0,77$ & $0,96 \pm 0,97$ \\
\hline
\end{tabular}


TABELA 5.10 - Valores médios e desvios padrão das medidas de distância interradicular (DI) mesial e distal, pré e pós-osteotomia, em milímetros.

\begin{tabular}{ccc}
\hline & Mesial & Distal \\
\hline DI pré-osteotomia & $1,62 \pm 0,57$ & $1,70 \pm 0,53$ \\
DI pós-osteotomia & $1,99 \pm 0,63$ & $2,16 \pm 0,57$ \\
\hline
\end{tabular}

TABELA 5.11 - Distribuição do número de sítios proximais (n) e sua porcentagem (\%) de acordo com presença e ausência de exposição óssea pós-sutura do retalho.

\begin{tabular}{ccccc}
\hline Exposição óssea & \multicolumn{2}{c}{ Mesial } & \multicolumn{3}{c}{ Distal } \\
\cline { 2 - 5 } & $\mathbf{n}$ & \% & $\mathbf{n}$ & \% \\
\hline Presença & 4 & 15,4 & 10 & 34,5 \\
Ausência & 22 & 84,6 & 19 & 65,5 \\
\hline
\end{tabular}

TABELA 5.12 - Valores médios e desvios padrão das medidas de junção mucogengival (JMG) e de mucosa ceratinizada (MC) vestibular na fase précirúrgica, cirúrgica e de controle pós-operatório de 1, 2, 3, 4, 5, 6 e 12 meses, em milímetros, e resultados da ANOVA e Teste de Tukey.

\begin{tabular}{llc}
\hline Fase & \multicolumn{1}{c}{ JMG } & MC \\
\hline Pré-cirúrgica & $12,08 \pm 1,78^{\mathrm{b}, \mathrm{c}}$ & $4,27 \pm 1,52^{\mathrm{a}}$ \\
Cirúrgica & $12,00 \pm 1,83^{\mathrm{c}}$ & $2,98 \pm 1,49^{\mathrm{b}}$ \\
$\mathbf{1}$ mês & $12,26 \pm 1,91^{\mathrm{a}, \mathrm{b}, \mathrm{c}}$ & $3,02 \pm 1,34^{\mathrm{b}}$ \\
$\mathbf{2}$ meses & $12,43 \pm 1,67^{\mathrm{a}}$ & $3,07 \pm 1,27^{\mathrm{b}}$ \\
$\mathbf{3}$ meses & $12,40 \pm 1,72^{\mathrm{a}, \mathrm{b}}$ & $3,08 \pm 1,24^{\mathrm{b}}$ \\
$\mathbf{4}$ meses & $12,39 \pm 1,65^{\mathrm{a}, \mathrm{b}}$ & $3,12 \pm 1,20^{\mathrm{b}}$ \\
$\mathbf{5}$ meses & $12,40 \pm 1,63^{\mathrm{a}}$ & $3,20 \pm 1,23^{\mathrm{b}}$ \\
$\mathbf{6}$ meses & $12,43 \pm 1,66^{\mathrm{a}}$ & $3,25 \pm 1,25^{\mathrm{b}}$ \\
$\mathbf{1 2}$ meses & $12,14 \pm 1,46^{\mathrm{a}, \mathrm{b}, \mathrm{c}}$ & $3,15 \pm 1,21^{\mathrm{b}}$ \\
\hline Períodos com a mesma letra não possuem diferenças estatisticamente significantes entre si $(\mathrm{p}>0,05)$
\end{tabular}


TABELA 5.13 - Valores médios e desvios padrão da localização do término cervical em relação à margem gengival nos sítios mesial, vestibular, lingual e distal na fase pré-cirúrgica, cirúrgica e de controle pós-operatório de 1, 2, 3, 4, 5, 6 e 12 meses, em milímetros.

\begin{tabular}{lcccc}
\hline Fase & Mesial & Vestibular & Lingual & Distal \\
\hline Pré-cirúrgica & $1,51 \pm 1,04$ & $-0,01 \pm 1,36$ & $0,73 \pm 0,54$ & $1,53 \pm 1,05$ \\
Cirúrgica & $-0,64 \pm 0,84$ & $-1,38 \pm 0,81$ & $-1,13 \pm 0,62$ & $-0,70 \pm 0,82$ \\
$\mathbf{1}$ mês & $-0,37 \pm 0,69$ & $-1,65 \pm 0,97$ & $-1,22 \pm 0,50$ & $-0,46 \pm 0,78$ \\
$\mathbf{2}$ meses & $-0,09 \pm 0,53$ & $-1,85 \pm 0,87$ & $-1,24 \pm 0,47$ & $-0,15 \pm 0,78$ \\
$\mathbf{3}$ meses & $0,03 \pm 0,50$ & $-1,87 \pm 0,89$ & $-1,09 \pm 0,56$ & $0,08 \pm 0,81$ \\
$\mathbf{4}$ meses & $0,16 \pm 0,69$ & $-1,85 \pm 0,96$ & $-0,89 \pm 0,50$ & $0,16 \pm 0,75$ \\
$\mathbf{5}$ meses & $0,33 \pm 0,73$ & $-1,74 \pm 1,05$ & $-0,92 \pm 0,67$ & $0,27 \pm 0,78$ \\
$\mathbf{6}$ meses & $0,43 \pm 0,69$ & $-1,74 \pm 0,94$ & $-0,94 \pm 0,60$ & $0,44 \pm 0,79$ \\
$\mathbf{1 2}$ meses & $0,77 \pm 0,74$ & $-1,43 \pm 0,73$ & $-0,70 \pm 0,59$ & $0,86 \pm 0,85$
\end{tabular}

Valor negativo - término cervical supragengival

Valor positivo - término cervical subgengival

TABELA 5.14 - Valores médios e desvios padrão das medidas de tecido gengival supra-ósseo nos sítios mesial, vestibular, lingual e distal na fase précirúrgica, cirúrgica e de controle pós-operatório de 6 e 12 meses, em milímetros, e resultados da ANOVA e Teste de Tukey.

\begin{tabular}{llllc}
\hline Fase & \multicolumn{1}{c}{ Mesial } & \multicolumn{1}{c}{ Vestibular } & \multicolumn{1}{c}{ Lingual } & Distal \\
\hline Pré-cirúrgica & $3,48 \pm 0,87^{\mathrm{b}}$ & $2,51 \pm 0,70$ & $3,05 \pm 0,86^{\mathrm{a}}$ & $3,40 \pm 0,98^{\mathrm{a}}$ \\
Cirúrgica & $2,43 \pm 0,80^{\mathrm{c}}$ & $2,50 \pm 0,62^{\mathrm{ns}}$ & $2,38 \pm 0,48^{\mathrm{b}}$ & $2,34 \pm 0,95^{\mathrm{b}}$ \\
${\text { 6 } \text { meses }^{*}}_{\text {12 }^{\text {meses }}}^{*}$ & $3,48 \pm 0,70^{\mathrm{a}, \mathrm{b}}$ & $2,24 \pm 0,67^{\mathrm{ns}}$ & $2,64 \pm 0,62^{\mathrm{a}, \mathrm{b}}$ & $3,44 \pm 0,93^{\mathrm{a}}$ \\
& $3,88 \pm 0,69^{\mathrm{a}}$ & $2,35 \pm 0,72^{\mathrm{ns}}$ & $2,86 \pm 0,67^{\mathrm{a}}$ & $3,84 \pm 1,06^{\mathrm{a}}$
\end{tabular}

* baseado na medida do nível ósseo pós-osteotomia

Períodos com a mesma letra não possuem diferenças estatisticamente significantes entre si $(p>0,05)$ ns - estatisticamente não significante $(p>0,05)$ 
TABELA 5.15 - Valores médios e desvios padrão das medidas de margem gengival nos sítios mesial, vestibular, lingual e distal na fase cirúrgica e de controle pós-operatório de 1, 2, 3, 4, 5, 6 e 12 meses, em milímetros, e resultados da ANOVA e Teste de Tukey.

\begin{tabular}{lllll}
\hline Fase & \multicolumn{1}{c}{ Mesial } & \multicolumn{1}{c}{ Vestibular } & \multicolumn{1}{c}{ Lingual } & \multicolumn{1}{c}{ Distal } \\
\hline Cirúrgica & $8,07 \pm 1,16^{\mathrm{a}}$ & $9,02 \pm 1,30^{\mathrm{d}}$ & $8,63 \pm 0,99^{\mathrm{a}, \mathrm{b}}$ & $8,32 \pm 0,97^{\mathrm{a}}$ \\
1 mês & $7,80 \pm 1,13^{\mathrm{b}}$ & $9,24 \pm 1,38^{\mathrm{b}, \mathrm{c}, \mathrm{d}}$ & $8,67 \pm 1,04^{\mathrm{a}}$ & $8,08 \pm 0,98^{\mathrm{b}}$ \\
2 meses & $7,47 \pm 1,07^{\mathrm{b}, \mathrm{c}}$ & $9,36 \pm 1,39^{\mathrm{a}}$ & $8,64 \pm 1,09^{\mathrm{a}, \mathrm{b}}$ & $7,74 \pm 0,90^{\mathrm{c}}$ \\
3 meses & $7,33 \pm 1,12^{\mathrm{c}, \mathrm{d}}$ & $9,32 \pm 1,41^{\mathrm{a}, \mathrm{b}}$ & $8,49 \pm 1,07^{\mathrm{a}, \mathrm{b}}$ & $7,50 \pm 0,91^{\mathrm{c}, \mathrm{d}}$ \\
$\mathbf{4}$ meses & $7,20 \pm 1,07^{\mathrm{d}, \mathrm{e}}$ & $9,27 \pm 1,46^{\mathrm{a}, \mathrm{b}, \mathrm{c}}$ & $8,37 \pm 1,05^{\mathrm{b}, \mathrm{c}}$ & $7,42 \pm 0,80^{\mathrm{d}}$ \\
$\mathbf{5}$ meses & $7,02 \pm 1,10^{\mathrm{e}}$ & $9,20 \pm 1,42^{\mathrm{a}, \mathrm{b}, \mathrm{c}, \mathrm{d}}$ & $8,38 \pm 1,15^{\mathrm{a}, \mathrm{b}, \mathrm{c}}$ & $7,31 \pm 0,90^{\mathrm{d}, \mathrm{e}}$ \\
6 meses & $6,94 \pm 1,03^{\mathrm{e}}$ & $9,18 \pm 1,39^{\mathrm{a}, \mathrm{b}, \mathrm{c}, \mathrm{d}}$ & $8,37 \pm 1,13^{\mathrm{b}, \mathrm{c}}$ & $7,13 \pm 0,90^{\mathrm{e}}$ \\
12 meses & $6,53 \pm 1,02^{\mathrm{f}}$ & $8,99 \pm 1,23^{\mathrm{c}, \mathrm{d}}$ & $8,09 \pm 0,98^{\mathrm{c}}$ & $6,74 \pm 0,86^{\mathrm{f}}$
\end{tabular}

Períodos com a mesma letra não possuem diferenças estatisticamente significantes entre si $(p>0,05)$

\section{Medidas da margem gengival}

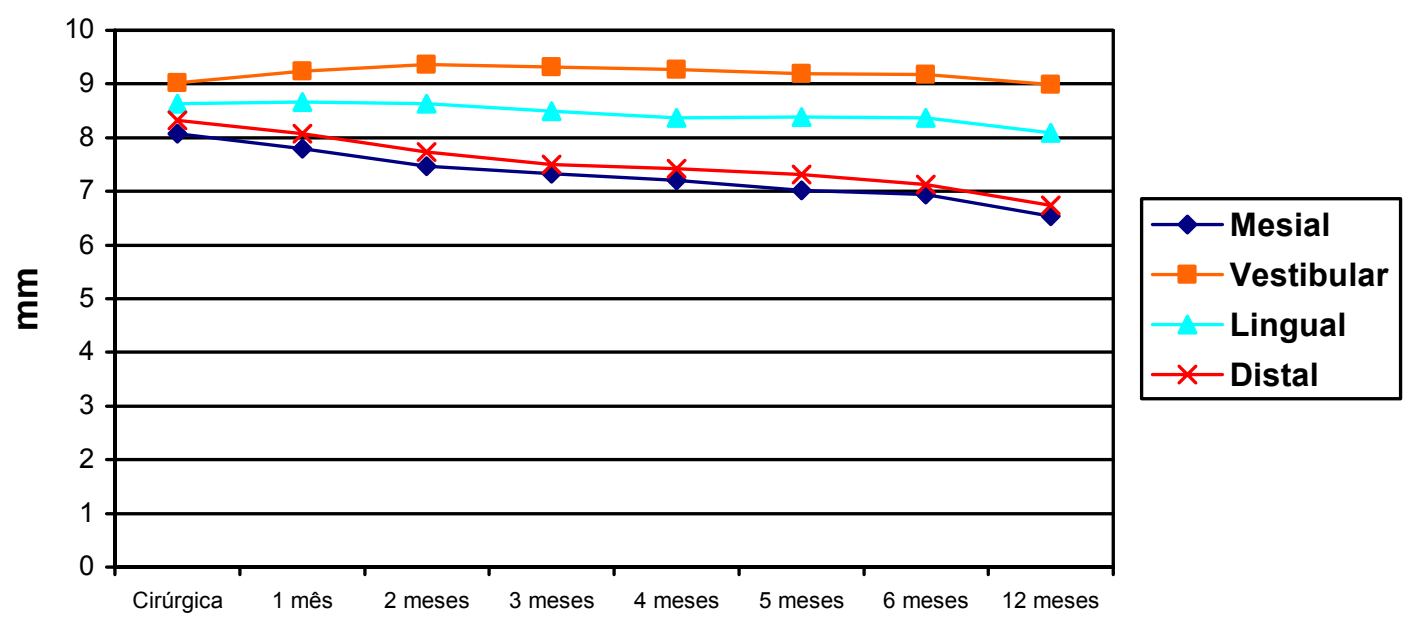

Fase

FIGURA 5.1 - Representação gráfica dos valores médios das medidas de margem gengival nos sítios mesial, vestibular, lingual e distal na fase cirúrgica e de controle pós-operatório de 1, 2, 3, 4, 5, 6 e 12 meses, em milímetros. 
TABELA 5.16 - Valores médios e desvios padrão de migração da margem gengival nos sítios mesial, vestibular, lingual e distal na fase de controle pósoperatório de 1, 2, 3, 4, 5, 6 e 12 meses, em milímetros, e resultados da ANOVA e Teste de Tukey.

\begin{tabular}{lllll}
\hline Fase & \multicolumn{1}{c}{ Mesial } & \multicolumn{1}{c}{ Vestibular } & \multicolumn{1}{c}{ Lingual } & \multicolumn{1}{c}{ Distal } \\
\hline 1 mês & $-0,26 \pm 0,52^{\mathrm{a}}$ & $0,22 \pm 0,58^{\mathrm{b}}$ & $0,04 \pm 0,50^{\mathrm{a}}$ & $-0,24 \pm 0,62^{\mathrm{a}}$ \\
$\mathbf{2}$ meses & $-0,55 \pm 0,53^{\mathrm{b}}$ & $0,40 \pm 0,54^{\mathrm{a}}$ & $0,05 \pm 0,63^{\mathrm{a}, \mathrm{b}}$ & $-0,56 \pm 0,54^{\mathrm{b}}$ \\
$\mathbf{3}$ meses & $-0,75 \pm 0,47^{\mathrm{b}, \mathrm{c}}$ & $0,39 \pm 0,55^{\mathrm{a}}$ & $-0,12 \pm 0,54^{\mathrm{a}, \mathrm{b}, \mathrm{c}}$ & $-0,80 \pm 0,64^{\mathrm{b}, \mathrm{c}}$ \\
$\mathbf{4}$ meses & $-0,88 \pm 0,49^{\mathrm{c}, \mathrm{d}}$ & $0,34 \pm 0,56^{\mathrm{a}, \mathrm{b}}$ & $-0,24 \pm 0,62^{\mathrm{c}, \mathrm{d}}$ & $-0,88 \pm 0,64^{\mathrm{c}}$ \\
$\mathbf{5}$ meses & $-1,06 \pm 0,51^{\mathrm{d}, \mathrm{e}}$ & $0,27 \pm 0,59^{\mathrm{a}, \mathrm{b}}$ & $-0,23 \pm 0,64^{\mathrm{b}, \mathrm{c}, \mathrm{d}}$ & $-1,00 \pm 0,64^{\mathrm{c}, \mathrm{d}}$ \\
$\mathbf{6}$ meses & $-1,14 \pm 0,48^{\mathrm{e}}$ & $0,26 \pm 0,49^{\mathrm{a}, \mathrm{b}}$ & $-0,24 \pm 0,62^{\mathrm{c}, \mathrm{d}}$ & $-1,17 \pm 0,60^{\mathrm{d}}$ \\
$\mathbf{1 2}$ meses & $-1,41 \pm 0,50^{\mathrm{f}}$ & $0,09 \pm 0,44^{\mathrm{b}}$ & $-0,47 \pm 0,65^{\mathrm{d}}$ & $-1,58 \pm 0,62^{\mathrm{e}}$
\end{tabular}

Períodos com a mesma letra não possuem diferenças estatisticamente significantes entre si $(p>0,05)$

Valor positivo - migração apical da margem gengival

Valor negativo - migração coronal da margem gengival

TABELA 5.17 - Valores médios e desvios padrão de aumento de coroa clínica aparente obtido nos sítios mesial, vestibular, lingual e distal na fase cirúrgica (pós-sutura) e de controle pós-operatório de 6 e 12 meses, em milímetros, e resultados da ANOVA e Teste de Tukey.

\begin{tabular}{lcccc}
\hline Fase & Mesial & Vestibular & Lingual & Distal \\
\hline Cirúrgica & $2,03 \pm 1,14^{\mathrm{a}}$ & $1,21 \pm 0,98^{\mathrm{b}}$ & $1,78 \pm 0,56^{\mathrm{a}}$ & $2,23 \pm 1,14^{\mathrm{a}}$ \\
$\mathbf{6}$ meses & $0,93 \pm 0,90^{\mathrm{b}}$ & $1,45 \pm 0,88^{\mathrm{a}}$ & $1,49 \pm 0,63^{\mathrm{a}, \mathrm{b}}$ & $1,07 \pm 1,10^{\mathrm{b}}$ \\
$\mathbf{1 2}$ meses & $0,52 \pm 0,98^{\mathrm{c}}$ & $1,39 \pm 0,78^{\mathrm{a}, \mathrm{b}}$ & $1,23 \pm 0,59^{\mathrm{b}}$ & $0,74 \pm 1,18^{\mathrm{c}}$
\end{tabular}


TABELA 5.18 - Distribuição do número de sítios (n) e valores médios e desvios padrão $(0 \pm d p)$ de migração margem gengival para apical (valor positivo) ou coronal (valor negativo) aos 12 meses, em relação à posição do retalho supraóssea pós-sutura, em milímetros.

\begin{tabular}{ccc}
\hline Posição do retalho & $\mathbf{n}$ & $0 \pm \mathbf{d p}$ \\
\hline $\mathbf{1} \mathbf{m m}$ & 7 & $-1,16 \pm 0,73$ \\
$\mathbf{2} \mathbf{m m}$ & 46 & $-0,85 \pm 0,95$ \\
$\mathbf{3 m m}$ & 43 & $-0,77 \pm 0,83$ \\
$\mathbf{4 m m}$ & 3 & $0,06 \pm 0,86$ \\
\hline
\end{tabular}

TABELA 5.19 - Teste de Correlação de Pearson entre medidas de margem gengival (MG) aos 6 e 12 meses e posição do retalho pós-sutura (Retalho), nos sítios mesial (M), vestibular (V), lingual (L) e distal (D).

\begin{tabular}{lcl}
\hline & $\mathbf{r}$ & $\mathbf{p}$ \\
\hline MG6 M x Retalho M & $-0,43$ & $0,038^{*}$ \\
MG6 V x Retalho V & $-0,33$ & 0,090 \\
MG6 L x Retalho L & $-0,41$ & $0,032^{*}$ \\
MG6 D x Retalho D & $-0,28$ & 0,149 \\
MG12 M x Retalho M & 0,26 & 0,250 \\
MG12 V x Retalho V & 0,77 & 0,709 \\
MG12 L x Retalho L & 0,34 & 0,090 \\
MG12 D x Retalho D & 0,07 & 0,745 \\
\hline
\end{tabular}



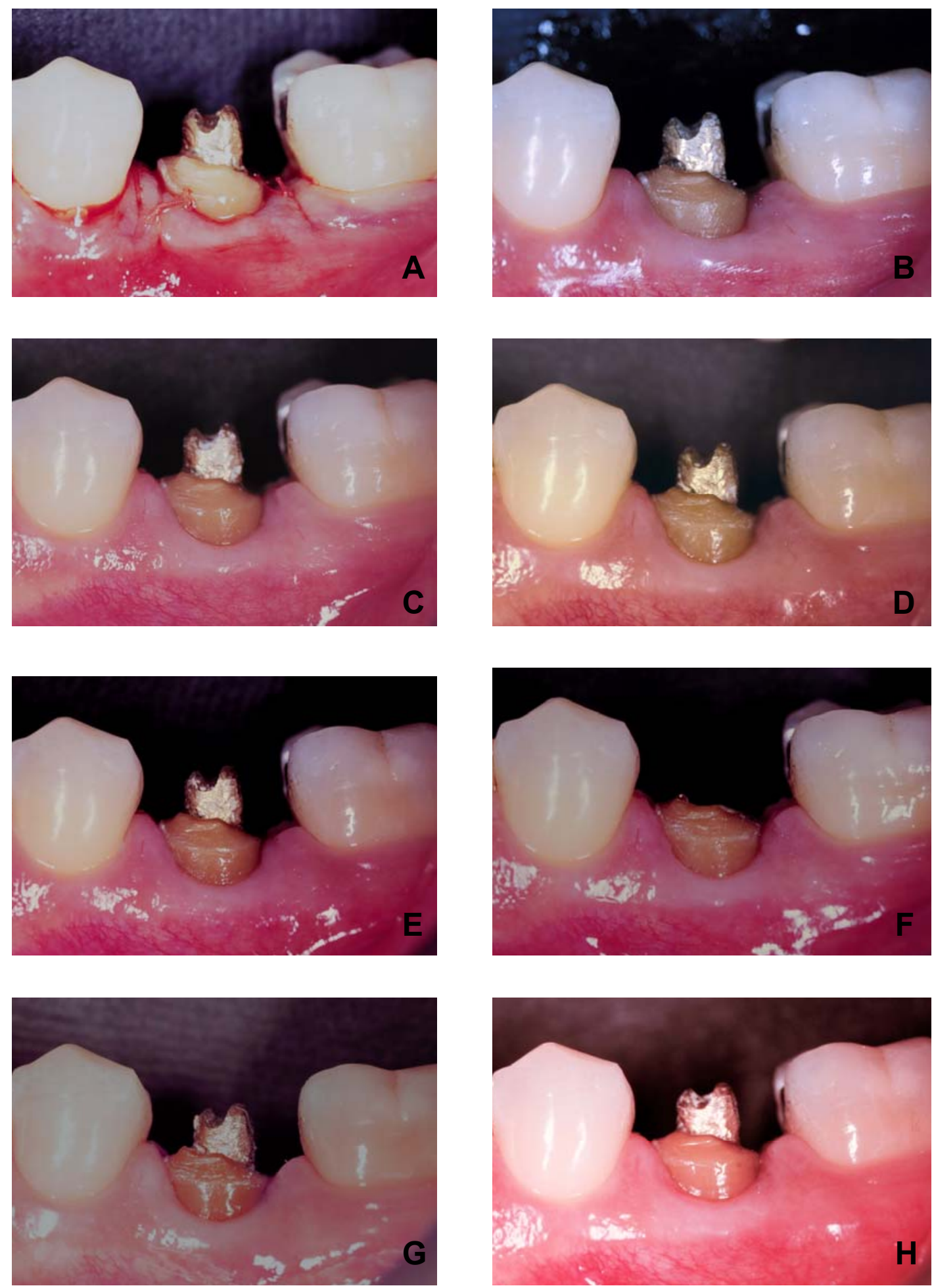

FIGURA 5.2 - Vista vestibular do segundo pré-molar imediatamente após sutura do retalho total coronal à crista óssea (A) Durante a fase de controle pós-operatório de 1 mês (B), 2 meses (C), 3 meses (D), 4 meses (E), 5 meses $(\mathbf{F}), 6$ meses $(\mathbf{G})$ e 12 meses $(\mathbf{H})$, houve migração da margem gengival para apical no sítio vestibular e para coronal nos sítios mesial e distal, a partir da margem do retalho pós-sutura. A papila gengival sem "dobra" foi observada após 3 meses na mesial e aos 12 meses na distal. 

TABELA 5.20 - Distribuição do número de sítios (n) e valores médios e desvios padrão $(0 \pm d p)$ da espessura da gengiva fina e espessa vestibular dos dentes pré-molares, em milímetros.

\begin{tabular}{lcc}
\hline & $\mathbf{n}$ & $0 \pm \mathbf{d p}$ \\
\hline Gengiva fina & 21 & $1,22 \pm 0,19$ \\
Gengiva espessa & 9 & $1,74 \pm 0,19$ \\
\hline
\end{tabular}

TABELA 5.21 - Distribuição das papilas gengivais mesial e distal com forma côncava, aspecto stippling e "dobra" na fase pré-cirúrgica e de controle pósoperatório de 1, 2, 3, 4, 5, 6 e 12 meses, em porcentagem.

\begin{tabular}{|c|c|c|c|c|c|c|}
\hline \multirow[b]{2}{*}{ Fase } & \multicolumn{2}{|c|}{ Forma côncava } & \multicolumn{2}{|c|}{ Aspecto stippling } & \multicolumn{2}{|c|}{ “Dobra" } \\
\hline & M & D & $\mathbf{M}$ & D & M & D \\
\hline Pré-cirúrgica & 46,2 & 51,7 & 19,2 & 17,2 & 51,9 & 75,9 \\
\hline 1 mês & 69,2 & $82,8^{*}$ & 11,5 & 6,9 & $100,0^{*}$ & $100,0^{*}$ \\
\hline 2 meses & 44,0 & 53,6 & 16,0 & 14,3 & $92,0^{*}$ & $100,0^{*}$ \\
\hline 3 meses & 28,0 & 42,9 & 28,0 & 14,3 & 80,0 & $96,4^{*}$ \\
\hline 4 meses & 24,0 & 28,6 & 20,0 & 21,4 & 76,0 & 85,7 \\
\hline 5 meses & 28,0 & 32,1 & 28,0 & 35,7 & 76,0 & 82,1 \\
\hline 6 meses & 32,0 & 35,7 & 52,0 & $50,0^{*}$ & 68,0 & 67,9 \\
\hline 12 meses & $4,2^{*}$ & $18,5^{\star}$ & $87,5^{*}$ & $74,1^{*}$ & $25,0^{*}$ & $40,7^{*}$ \\
\hline
\end{tabular}




\subsection{Avaliação radiográfica}

TABELA 5.22 - Distribuição do número de cristas ósseas (n) mesial e distal e sua porcentagem (\%) de acordo com presença de lâmina dura na fase de controle pós-operatório de 2, 3, 6 e 12 meses.

\begin{tabular}{lcccc}
\hline \multirow{2}{*}{ Fase } & \multicolumn{2}{c}{ Crista óssea mesial } & \multicolumn{2}{c}{ Crista óssea distal } \\
\cline { 2 - 5 } & $\mathrm{n}$ & $\%$ & $\mathrm{n}$ & $\%$ \\
\hline $\mathbf{2}$ meses & 0 & 0 & 0 & 0 \\
$\mathbf{3}$ meses & 1 & 4,3 & 1 & 3,7 \\
$\mathbf{6}$ meses & 14 & 60,9 & 18 & 66,7 \\
$\mathbf{1 2}$ meses & 21 & 100,0 & 25 & 100,0 \\
\hline
\end{tabular}

TABELA 5.23 - Valores médios e desvios padrão das medidas da distância entre término cervical e crista óssea mesial e distal na fase pré-cirúrgica, cirúrgica e de controle pós-operatório de 2, 3, 6 e 12 meses, em milímetros, e resultados da ANOVA e Teste de Tukey.

\begin{tabular}{lcc}
\hline Fase & Mesial & Distal \\
\hline Pré-cirúrgica & $2,10 \pm 1,37^{\mathrm{a}}$ & $1,54 \pm 0,65^{\mathrm{a}}$ \\
Cirúrgica & $3,28 \pm 0,87^{\mathrm{b}}$ & $2,81 \pm 0,51^{\mathrm{b}}$ \\
$\mathbf{2}$ meses & $3,41 \pm 0,92^{\mathrm{b}}$ & $2,90 \pm 0,54^{\mathrm{b}}$ \\
$\mathbf{3}$ meses & $3,44 \pm 0,97^{\mathrm{b}}$ & $2,93 \pm 0,53^{\mathrm{b}}$ \\
$\mathbf{6}$ meses & $3,46 \pm 0,92^{\mathrm{b}}$ & $2,95 \pm 0,53^{\mathrm{b}}$ \\
$\mathbf{1 2}$ meses & $3,39 \pm 0,87^{\mathrm{b}}$ & $2,97 \pm 0,55^{\mathrm{b}}$ \\
\hline Periodos com a mesma letra não possuem diferenças estatisticamente significantes entre si $(\mathrm{p}>0,05)$
\end{tabular}


TABELA 5.24 - Valores médios e desvios padrão das alterações no nível ósseo mesial e distal na fase cirúrgica e de controle pós-operatório de 2, 3, 6 e 12 meses, em milímetros, e resultados da ANOVA e Teste de Tukey.

\begin{tabular}{lcc}
\hline Fase & Mesial & Distal \\
\hline Cirúrgica & $1,17 \pm 0,79^{\mathrm{a}}$ & $1,26 \pm 0,67^{\mathrm{a}}$ \\
$\mathbf{2}$ meses & $0,16 \pm 0,18^{\mathrm{b}}$ & $0,06 \pm 0,15^{\mathrm{b}}$ \\
$\mathbf{3}$ meses & $0,17 \pm 0,26^{\mathrm{b}}$ & $0,10 \pm 0,16^{\mathrm{b}}$ \\
$\mathbf{6}$ meses & $0,19 \pm 0,25^{\mathrm{b}}$ & $0,12 \pm 0,18^{\mathrm{b}}$ \\
$\mathbf{1 2}$ meses & $0,15 \pm 0,24^{\mathrm{b}}$ & $0,09 \pm 0,20^{\mathrm{b}}$ \\
\hline
\end{tabular}

Períodos com a mesma letra não possuem diferenças estatisticamente significantes entre si $(p>0,05)$

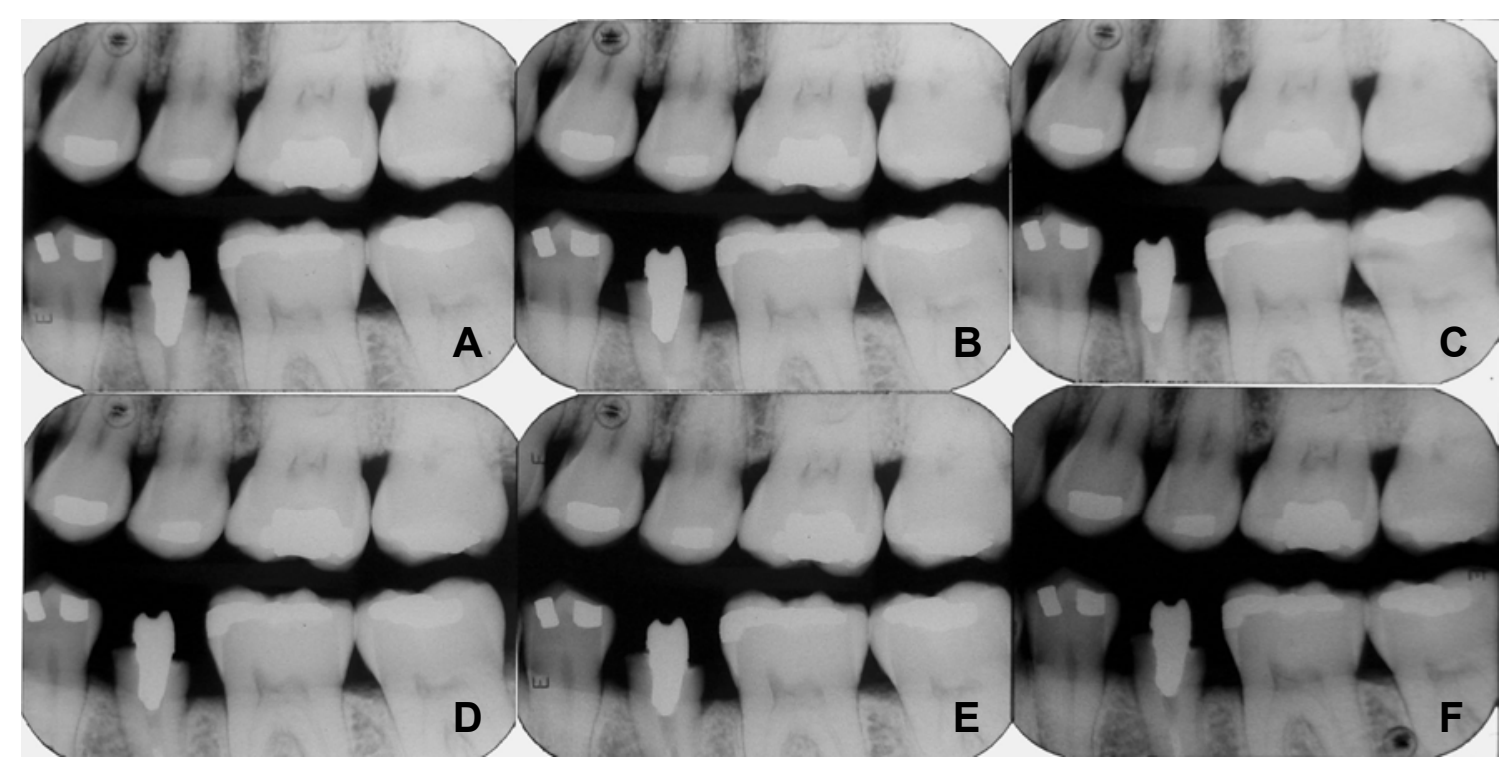

FIGURA 5.3 - Radiografia interproximal do segundo pré-molar inferior esquerdo antes da cirugia (A), após osteotomia (B) e aos 2 meses (C), 3 meses (D), 6 meses (E) e 12 meses $(\mathbf{F})$ após cirurgia. A presença da lâmina dura intacta foi observada na crista óssea mesial aos 6 meses e na crista óssea distal, aos 12 meses. 

DISCUSSÃO 



\section{DISCUSSÃO}

\section{1 - Avaliação clínica}

A posição da margem gengival e a profundidade de sondagem são parâmetros clínicos utilizados freqüentemente pelos profissionais no diagnóstico e planejamento de diferentes procedimentos odontológicos. A alteração na posição da margem gengival interfere na execução de procedimentos restauradores, principalmente em áreas estéticas, quando se deseja localizar o término cervical de um preparo para coroa protética subgengivalmente ${ }^{1}$. Por isso, torna-se imprescindível alcançar a estabilidade da margem gengival após cirurgia periodontal ${ }^{74}$.

"Creeping attachment" é um fenômeno clínico que foi descrito por GOLDMAN $^{24}$ (1964) como migração do tecido gengival marginal pós-operatório em direção coronal, cobrindo parcial ou totalmente a porção da raiz vestibular previamente exposta, após procedimentos mucogengivais. Segundo o autor, esta migração ocorreu continuamente por longos períodos pós-operatórios até que um nível marginal consistente fosse alcançado. Esse tecido gengival foi relatado estar firmemente inserido à raiz, sem aumento na profundidade do sulco gengival clínico. Apesar desse fenômeno ter sido baseado apenas em observação clínica, os estudos de AFSHAR-MOHAJER ${ }^{1}$ (1977) e BELL et al. ${ }^{8}$ (1978) foram os primeiros a comprovarem cientificamente a sua ocorrência após cirurgia. AFSHAR-MOHAJER ${ }^{1}$ (1977) observou um crescimento médio da margem gengival vestibular para coronal de $1,2 \mathrm{~mm}$ ao final de 12 semanas após cirurgia de gengivectomia. BELL et al. ${ }^{8}$ (1978) verificaram migração média 
de $0,89 \pm 0,46 \mathrm{~mm}$ (variando de $0,38 \mathrm{~mm}$ a $1,61 \mathrm{~mm}$ ) para coronal durante período de 1 ano após realização de enxerto gengival livre.

Alterações na margem gengival vestibular também foram relatadas por LINDHE; NYMAN ${ }^{36}$ (1980) após cirurgia de retalho de espessura parcial posicionado apicalmente com ressecção óssea para eliminação de bolsas periodontais profundas e defeitos ósseos. Uma migração apical de 3,0mm para $5,5 \mathrm{~mm}$ da margem gengival em relação à junção cemento-esmalte foi observado em todos os dentes após 2 meses de reparação e um crescimento médio coronal de $1 \mathrm{~mm}$ após período de manutenção de 10 a 11 anos. Os autores relacionaram este crescimento coronal como resultado da maturação tecidual e não do edema decorrente da inflamação gengival, uma vez que a saúde periodontal foi avaliada a intervalos de 3 a 6 meses, durante todo período de avaliação. Nos sítios proximais, migração coronal da margem gengival também foi observada após cirurgia de retalho de espessura total e debridamento, sem ressecção óssea. VAN DER VELDEN ${ }^{67}$ (1982) relatou um crescimento médio coronal de $4,33 \mathrm{~mm}$, a partir do nível ósseo proximal completamente exposto após sutura dos retalhos. Os pacientes foram reavaliados a cada 6 meses até completar 3 anos de avaliação.

Apesar desses estudos clínicos longitudinais comprovarem a ocorrência de migração coronal da margem gengival, não puderam determinar em qual período de tempo a margem alcançou sua estabilidade. Segundo INGBER; ROSE; COSLET ${ }^{29}$ (1977), a posição estável da margem gengival, ao final do processo de reparo, poderia ser prevista no momento da cirurgia pelo conhecimento do conceito de distância biológica. Baseado no estudo de GARGIULO; WENTZ; ORBAN ${ }^{23}$ (1961), COHEN ${ }^{17}$ (1962) denominou de distância biológica (média de 2,04mm) a medida da base do sulco gengival até crista óssea, ou seja, a soma das medidas médias da inserção conjuntiva $(1,07 \mathrm{~mm})$ e epitélio juncional $(0,97 \mathrm{~mm})$. Entretanto, NEVINS; SKUROW ${ }^{42}$ (1984) definiram distância biológica como o espaço ocupado pelo sulco gengival, epitélio juncional e inserção conjuntiva. Independente da inclusão ou não da medida do sulco gengival como parte da medida da distância biológica, o mais importante é o conhecimento de que essas três estruturas integram o 
tecido gengival supra-ósseo ao redor dos dentes. No presente estudo, o termo distância biológica foi empregado para se referir à soma da medida da inserção conjuntiva e epitélio juncional, excluindo-se a medida do sulco gengival ${ }^{17}$. Isso permitiu estabelecer como invasão do espaço da distância biológica, no caso em que o término cervical estivesse localizado subgengivalmente, a uma distância $\leq 2 \mathrm{~mm}$ da crista óssea.

A aplicação desse conceito de distância biológica durante execução de procedimentos restauradores, permite ao profissional manter a saúde dos tecidos periodontais marginais ao redor dos dentes e, em outros casos, permite recuperar sua saúde. Neste último caso, a cirurgia de aumento de coroa tem sido indicada quando cárie, fratura dentária, perfuração endodôntica, reabsorção radicular ou término cervical pré-existente invadem o espaço do epitélio juncional e inserção conjuntiva, causando inflamação periodontal. A técnica cirúrgica de aumento de coroa preconizada por INGBER; ROSE; $\operatorname{COSLET}^{29}$ (1977) expõe, no mínimo, 3mm de estrutura dentária saudável coronal à crista óssea, para permitir formação de um nova inserção conjuntiva e epitélio juncional, além da formação do sulco gengival. Por meio de um estudo clínico longitudinal controlado, PONTORIERO; CARNEVALE ${ }^{49}$ (2001) confirmaram a ocorrência dessa migração coronal da margem gengival a partir do nível do retalho de espessura parcial, suturado ao nível ou apical à crista óssea. Posteriormente, DEAS et al. ${ }^{18}$ (2004) verificaram que a sutura da margem do retalho total coronal à crista óssea (ao nível ou apical à margem da restauração) foi relacionada a uma menor quantidade de alteração da margem gengival durante processo de reparo.

Dessa forma, este estudo procurou monitorar as alterações no nível da margem gengival durante processo de reparo após cirurgia de aumento de coroa com finalidade restauradora em dentes pré-molares. Para a técnica cirúrgica descrita, com retalho total reposicionado e suturado coronal à crista óssea e apical ao término cervical, será utilizado o termo "retalho reposicionado coronal à crista óssea". Assim, os resultados obtidos pela técnica do retalho reposicionado coronal à crista óssea foram comparados aos resultados 
encontrados na literatura ${ }^{12,18,35,49}$ com a técnica do retalho posicionado apicalmente.

Com relação à amostra, foram selecionados somente dentes prémolares (Tabela 5.1), diferente do estudo de BRÄGGER; LAUCHENAUER; $\mathrm{LANG}^{12}$ (1992), que incluíram na amostra incisivos, caninos, pré-molares e molares, e de DEAS et al. $^{18}$ (2004), que incluíram pré-molares e molares. Apesar da alta freqüência dos molares com indicação para essa técnica cirúrgica ressectiva, os mesmos foram excluídos da amostra, devido a dificuldade de visualização das medidas clínicas com uso de placa oclusal, dificuldade de coaptação dos retalhos após sutura ${ }^{31}$ e dificuldade de remoção da placa bacteriana pelo paciente. Além disso, os resultados obtidos por DIBART et al. ${ }^{19}$ (2003), a partir de uma amostra de 26 dentes molares inferiores, demonstrando evidência radiográfica de lesão de furca em 38,5\% dos dentes, 5 anos após cirurgia de aumento de coroa, também contribuíram para a exclusão de dentes molares da amostra. Os dentes anteriores também foram excluídos, pois a técnica da tração dentária rápida, associada ou não à cirurgia periodontal, tem sido indicada para manter o nível da margem gengival inalterada nos dentes adjacentes, sem comprometer a estética ${ }^{58}$.

A faixa etária dos 23 pacientes selecionados, com ausência de alteração no nível de inserção clínica nos sítios $M$ e $D$ dos dentes pré-molares, foi de 20 a 45 anos de idade, menor do que aquela relatada em outros estudos $^{12,19,35,49}$. A causa mais freqüente para indicação cirúrgica foi a presença da cárie dentária, seguido da fratura dentária, numa distância $\leq 2 \mathrm{~mm}$ da crista óssea alveolar (Figura 5.1). Os sítios D (21 sítios) foram mais acometidos do que os sítios M (13 sítios), V (9 sítios) e L (12 sítios) (Tabela 5.2).

O controle profissional das áreas tratadas cirurgicamente foi realizado semanalmente para assegurar efetivo controle de placa no primeiro mês pós-cirúrgico, e mensalmente, até completar 6 meses de avaliação. Nenhum controle profissional foi realizado entre os períodos de 6 e 12 meses. A porcentagem média inicial (fase pré-cirúrgica) dos sítios $M$ e $D$ com placa 
bacteriana foi de $86,7 \%$, com redução estatisticamente significante para $37,0 \%$ nos sítios $M$ e para $44,4 \%$ nos sítios $D$, aos 12 meses (Tabela 5.3). A presença de placa foi encontrada mais frequentemente nas concavidades vestíbulolinguais. Além do uso de fio dental, a técnica complementar de controle de placa pelo paciente nesses sítios foi aquela descrita por SHAPIRO ${ }^{59}$ (1985), ou seja, uso de escova interdental com uma leve pressão aplicada contra a superfície dentária, e não em direção ao tecido gengival, o que poderia impedir o crescimento coronal da papila gengival. A troca da escova interdental cilíndrica para um diâmetro menor ou a suspensão do seu uso foi orientada quando houvesse dificuldade de sua introdução no espaço interdentário.

Com a técnica de escovação de $\operatorname{BASS}^{5}$ (1954), os pacientes mantiveram um ótimo controle de placa bacteriana nos sítios $\mathrm{V}$, com redução significante na porcentagem média de sítios com placa, de $36,7 \%$ para $3,7 \%$. Mesmo com a orientação do uso complementar de escova unitufo, a porcentagens médias de sítios $\mathrm{L}$ com placa permaneceram elevadas durante todo estudo, variando de $66,7 \%$ na fase pré-cirúrgica para $74,1 \%$ aos 12 meses.

Os valores do índice de placa de SILNESS; LÖE ${ }^{60}$ (1964) apresentados por BRÄGGER; LAUCHENAUER; LANG ${ }^{12}$ (1992) $(0,27$ a 0,52), PONTORIERO; CARNEVALE ${ }^{49}$ (2001) $\left(0,3\right.$ a 0,4) e LANNING et al. ${ }^{35}$ (2003) $(0,41$ a 0,62$)$ foram inferiores a escore 1 , variando entre placa ausente e sua visualização com sonda ou solução evidenciadora. Apesar dessa análise de índice não ter sido utilizada no presente trabalho, com aplicação de uma solução evidenciadora foi possível verificar que cerca de $60 \%$ dos sítios não apresentaram placa aos 12 meses, sugerindo um índice entre escore 0 e 1 .

As porcentagens médias inicial e final de todos os sítios com placa relatados por DEAS et al. ${ }^{18}$ (2004) (de 26,3\% para 25,7\%) foram menores do que os valores encontrados neste estudo (de $69,2 \%$ para $39,8 \%$ ). Ambos os estudos empregaram o mesmo índice dicotômico para placa bacteriana. A sua escolha baseou-se no conhecimento de que presença da placa causa inflamação gengival, independente de sua quantidade. Apesar de não terem sido realizados controles profissionais mensais nos últimos 6 meses, os 
pacientes apresentaram uma habilidade técnica na remoção de placa, adequada para a saúde gengival, como observado na Tabela 5.4.

A porcentagem média de sítios $M, V, L$ e $D$ com sangramento gengival foi de $46,2 \%, 16,7 \%, 36,7 \%$ e $72,4 \%$ na fase pré-cirúrgica, reduzindo para $4,8 \%, 0 \%, 19,2 \%$ e $12,5 \%$ aos 12 meses, respectivamente (Tabela 5.4 ). Essa redução foi estatisticamente significante, exceto para os sítios $\mathrm{L}$, como esperado pela alta porcentagem média de sítios com placa observado durante todo o estudo (Tabela 5.3). A recuperação cirúrgica do espaço para distância biológica associada ao controle adequado de placa reduziu significantemente a inflamação gengival proximal, tanto nos sítios $M$ e $D$ como nos sítios $D$ adjacentes (Da) e M adjacentes (Ma). No estudo de DEAS et al. ${ }^{18}$ (2004), a porcentagem média total dos sítios com sangramento à sondagem reduziu de $26,6 \%$ para $22,0 \%$, e neste estudo, a redução foi maior, de $43,0 \%$ para $9,1 \%$.

Os valores do índice gengival de LÖE; SILNESS ${ }^{37}$ (1963) relatados por BRÄGGER; LAUCHENAUER; LANG ${ }^{12}$ (1992) (0,78 a 0,92), PONTORIERO; CARNEVALE ${ }^{49}$ (2001) $\left(0,5\right.$ a 0,8) e LANNING et al. $^{35}(2003)$ $(0,34$ a 0,73$)$ não ultrapassaram o escore 1 , ou seja, sítios com ausência de inflamação a sítios com leve alteração de cor e textura. Mesmo não sendo utilizado esse índice, como a maioria dos sítios (90,9\%) neste estudo apresentou ausência de inflamação aos 12 meses, o índice poderia estar entre 0 e 1.

O método de escolha para obtenção dos parâmetros clínicos de nível de inserção relativo, nível ósseo, junção mucogengival, término cervical e margem gengival, durante 12 meses, foi uso de sonda periodontal manual e placa oclusal com pontos de referências, que possibilitaram a padronização da localização e angulação da sonda ${ }^{30}$. Todas as medidas foram realizadas somente por um examinador. BADERSTEN; NILVEUS; EGELBERG ${ }^{4}$ (1984) e CLARK et al. $^{15}$ (1987) suportaram o uso de placa referencial e sonda periodontal manual na melhora da confiabilidade e reprodutibilidade intraexaminadores de medidas comparadas. 
PONTORIERO; CARNEVALE ${ }^{49}$ (2001) e DEAS et al. $^{18}$ (2004) realizaram medidas de sondagem após primeiro mês de reparação e BRÄGGER; LAUCHENAUER; LANG ${ }^{12}$ (1992) após 6 semanas. No presente trabalho, as medidas de sondagem foram obtidas somente a partir do segundo mês, a fim de não perturbar o processo de reparo do tecido gengival supraósseo ${ }^{1,36}$.

Apesar dos retalhos terem sido suturados coronal à crista óssea, a medida média de PS inicial de 2,12mm (sítios $M$ ), 1,72mm (sítios V), 1,80mm (sítios $L$ ) e 2,36mm (sítios $D$ ), diminuiu para 1,92mm (sítios $M$ ), 1,28mm (sítios V), 1,75mm (sítios L) e 1,93mm (sítios D) aos 2 meses, alcançando valores de 2,28mm (sítios M), 1,36mm (sítios V), 1,97mm (sítios L) e 2,71mm (sítios D) ao final de 12 meses (Tabela 5.5). Somente para os sítios $V$ foi observada diferença estatisticamente significante entre as medidas inicial (pré-cirúrgica) e de 12 meses, sendo essa diferença clinicamente não significante. Resultados similares foram observados por PONTORIERO; CARNEVALE ${ }^{49}$ (2001), cujos valores de PS reduziram após 1 mês e retornaram gradualmente aos valores pré-cirúrgicos (sítios proximais: 2,7mm e V/L: 1,4mm) após 12 meses (sítios proximais: $2,8 \mathrm{~mm}$ e $\mathrm{V} / \mathrm{L}: 1,3 \mathrm{~mm}$ ), em todos os sítios. O mesmo comportamento das medidas de PS também foi relatado por DEAS et al. ${ }^{18}$ (2004) e BRÄGGER; LAUCHENAUER; LANG ${ }^{12}$ (1992), num período de avaliação menor (6 meses). No estudo de LANNING et al. ${ }^{35}$ (2003), as medidas médias de PS inicial e aos 6 meses também não apresentaram diferenças significantes nos sítios tratados (de 2,30mm para $3,17 \mathrm{~mm}$ ), como também, nos sítios adjacentes (de 2,57mm para 2,53mm) e não adjacentes (de 2,53mm para 2,49mm). De acordo com a Tabela 5.5, as medidas médias iniciais de PS nos sítios Da e Ma também não diferiram significantemente das medidas obtidas aos 12 meses.

Com relação à medida média do nível de inserção relativo (NIR), houve perda de inserção (diferença entre as medidas pós-cirúrgica e inicial) estatisticamente significante 2 meses após cirurgia em todos os sítios (Tabela 5.6). A partir desse período, as alterações nas medida de NIR não foram estatisticamente significantes, verificando-se uma perda média de inserção de 0,64mm, 0,81 mm, 1,40mm e 0,97mm, respectivamente, para sítios $M, V, L$ e $D$, 
aos 12 meses. PONTORIERO; CARNEVALE ${ }^{49}$ (2001) observaram perda média de inserção de $0,6 \mathrm{~mm}$ nos sítios proximais e $1,1 \mathrm{~mm}$ nos sítios $\mathrm{V} / \mathrm{L}$, e no presente estudo, foi de $0,8 \mathrm{~mm}$ e $1,1 \mathrm{~mm}$, respectivamente. DEAS et al. ${ }^{18}$ (2004) notaram que a perda de inserção aos 6 meses foi significante, com média de $1,24 \mathrm{~mm}$, similar ao presente trabalho $(1,26 \mathrm{~mm})$. Para os sítios adjacentes, a perda média de inserção observada aos 12 meses foi de $0,47 \mathrm{~mm}$ (sítios Da) e de 0,63mm (sítios Ma).

A perda de inserção pós-cirúrgica é um resultado esperado como conseqüência da ressecção óssea realizada para expor estrutura dentária supra-óssea suficiente para distância biológica. HERRERO et al. ${ }^{28}$, em 1995, observaram que a distância mínima de $3 \mathrm{~mm}$ entre crista óssea e término cervical não foi alcançada, mesmo por profissionais especializados (média de 2,6mm). Apesar dos profissionais mais experientes terem removido uma maior quantidade de osso $(1,1 \pm 0,6 \mathrm{~mm})$ do que outros cirurgiões (estudantes de $1^{\circ} \mathrm{e}$ $2^{\circ}$ ano removeram, em média, $0,0 \pm 0,7 \mathrm{~mm}$ e $0,8 \pm 0,5 \mathrm{~mm}$, respectivamente), nenhuma correlação foi encontrada entre nível de experiência profissional e distância obtida. Talvez a medida tenha sido variável em função da técnica cirúrgica empregada no estudo, incluindo procedimento de gengivectomia e retalho posicionado apicalmente com e sem ressecção óssea, erro na indicação destas técnicas ou localização subgengival do término cervical. $\mathrm{Na}$ técnica da gengivectomia remove-se parte do tecido gengival supra-ósseo para obter aumento de coroa clínica aparente, sem acesso à crista óssea.

Neste estudo, a mesma técnica cirúrgica foi empregada em todos os casos e executada apenas por um profissional especializado, como realizado no estudo de LANNING et al. ${ }^{35}$ (2003). Isso contribuiu para que a medida mínima de $3 \mathrm{~mm}$ fosse alcançada em todos os sítios que apresentavam invasão do espaço para distância biológica (Tabela 5.7). Com relação à ressecção óssea (RO), DEAS et al. ${ }^{18}$ (2004) verificaram também que a exposição da superfície radicular saudável (para aumento de coroa ou restabelecimento da distância de $3 \mathrm{~mm}$ ) geralmente é requerida em 1 ou 2 sítios preferível do que ao redor do dente, enquanto os outros sítios apresentam mínima ou mesmo nenhuma necessidade de RO. Assim, RO $>2 \mathrm{~mm}$ foi observada apenas em 
$1,2 \%, 6,5 \%, 4,0 \%$, e 1,7\%, respectivamente, nos estudos de PONTORIERO; CARNEVALE $^{49}$ (2001), DEAS et al. ${ }^{18}$ (2004), BRÄGGER; LAUCHENAUER; LANG $^{12}$ (1992) e neste estudo (Tabela 5.8), com 20\%, 23,6\%, 38\% e 45,2\% dos sítios tratados sem alterações no nível da crista óssea após cirurgia, respectivamente.

A quantidade média de RO no estudo de PONTORIERO; CARNEVALE $^{49}$ (2001) e neste estudo (Tabela 5.9) para os sítios proximais/livres, foi de $0,9 \mathrm{~mm} / 1,0 \mathrm{~mm}$ e $1,1 \mathrm{~mm} / 1,2 \mathrm{~mm}$, respectivamente, similar ao estudo de DEAS et al. ${ }^{18}$ (2004) (média total de $1,13 \mathrm{~mm}$ ). LANNING et al. ${ }^{35}$ (2003) relataram a maior quantidade de RO citada na literatura para cirurgia de aumento de coroa clínica com finalidade restauradora, média de $2,68 \mathrm{~mm}$, com $90 \%$ dos sítios com redução no nível ósseo $\geq 3 \mathrm{~mm}$.

Quando uma cirurgia a retalho com ressecção óssea for indicada em um dente, a arquitetura óssea deve ser reproduzida num nível mais apical, estendendo-se aos dentes adjacentes para promover uma transição suave com o contorno ósseo adjacente ${ }^{58}$. Por isso, a quantidade média de RO realizada é maior nos sítios tratados do que nos sítios proximais dos dentes adjacentes $^{18,35}$, corroborando com os dados apresentados na Tabela 5.9.

Após $\mathrm{RO}$ e raspagem radicular, as margens dos retalhos foram inicialmente adaptadas ao redor das faces $V$ e $L$ do pré-molar e em seguida, as margens proximais, com o cuidado de evitar sobreposição dos tecidos ou exposição óssea proximal. Segundo WENNSTRÖM et al..$^{71}$ (1989), os retalhos totais $\mathrm{V}$ e $\mathrm{L}$ posicionados e suturados preservam o epitélio oral na fase pósoperatória, tornando o uso de cimento cirúrgico desnecessário. Neste estudo, como os retalhos foram reposicionado e suturados coronal à crista óssea nos sítios $M, V, L$ e $D$, procurando cobrir ao máximo as cristas ósseas proximais, não foi utilizado cimento cirúrgico. Dos 55 sítios proximais, 41 (74,5\%) não apresentaram exposição óssea proximal após sutura, permitindo reparação por primeira intenção (Tabela 5.11). Nos sítios $D$ houve maior freqüência de exposição óssea (34,5\%) quando comparada aos sítios $M(15,4 \%)$, provavelmente devido às dificuldades técnicas, como acesso para incisão e 
rebatimento do retalho total com preservação do tecido gengival proximal. $\mathrm{E}$ quando este tecido gengival apresentava-se irregular, muito estreito ou com uma coloração azulada no momento da sutura, foi regularizada ou excisada, o que resultou em exposição da crista óssea alveolar e reparação por segunda intenção. Na técnica do retalho posicionado e suturado apicalmente por meio de suturas no periósteo, como realizado por PONTORIERO; CARNEVALE ${ }^{49}$ (2001), osso proximal permanece completamente exposto, tornando necessária sua proteção com cimento cirúrgico.

Apesar da utilização de retalhos totais reposicionados sem uso de suturas ancoradas no periósteo, nenhuma migração coronal no nível da junção mucogengival (JMG) vestibular foi observada em todos os períodos de avaliação, como observado na Tabela 5.12. A ausência de incisões relaxantes verticais e o rebatimento do retalho total aquém da JMG podem ter contribuído para a ausência de migração coronal do retalho $\mathrm{V}$.

A realização de uma incisão em bisel interno nos sítios $V$ e $L$ dos pré-molares definiu uma nova margem gengival localizada mais apicalmente e, como conseqüência, reduziu significantemente a quantidade (altura) de mucosa ceratinizada (MC) de 4,27mm para 2,98mm (Tabela 5.12). Durante período de reparação, não houve alterações significantes na sua quantidade. A redução na quantidade de MC após incisão representa uma desvantagem da técnica, principalmente, para áreas onde a sua eliminação poderia comprometer a saúde periodontal. Neste estudo, a quantidade média de $3 \mathrm{~mm}$ de MC associada ao ótimo controle de placa bacteriana pelo paciente (Tabela 5.3) foi suficiente para manter a saúde da margem gengival $V$.

Essa incisão em bisel interno, com remoção do "colar" de tecido gengival, resultou em aumento de coroa clínica aparente e localização supragengival dos términos cervicais (TC) nos sítios $V$ e L, mesmo após sutura dos retalhos coronal à crista óssea (Tabela 5.13 - fase cirúrgica), permanecendo nesse nível até o final do estudo, em média, 1,43mm (sítios V) e 0,70mm (sítios L). Nos sítios $M$ e D, a localização inicial dos TC, em média, 1,5mm subgengival, localizaram-se 0,64mm (sítios $M$ ) e 0,70mm (sítios D) 
supragengivalmente após sutura dos retalhos. A partir do $3^{\circ}$ mês, os TC estavam localizados no nível da margem gengival e aos 12 meses estavam posicionados $0,77 \mathrm{~mm}$ (sítios $\mathrm{M}$ ) e $0,86 \mathrm{~mm}$ (sítios $\mathrm{D}$ ) subgengivalmente. Como os preparos dentários foram mantidos inalterados durante todo período de avaliação, as mudanças na localização dos TC, de nível supragengival para subgengival, demonstram que houve migração da margem gengival para coronal (Figura 5.2).

Para melhor compreensão das alterações na margem gengival durante processo de reparo de 12 meses, os resultados obtidos foram comparados com a literatura, envolvendo os seguintes aspectos:

\section{1) Padrão de alteração da margem gengival}

Baseado nos resultados apresentados nas Tabelas 5.15 e 5.16 e Figuras 5.1 e 5.2, e corroborando com PONTORIERO; CARNEVALE ${ }^{49}$ (2001) e DEAS et al. $^{18}$ (2004), pode-se observar um padrão no comportamento da margem gengival ( $M G)$ nos sítios $M$ e $D$, com tendência à migração coronal a partir do nível do retalho pós-sutura, independente da posição do retalho suturado em relação à crista óssea. Contudo, a magnitude dessa migração foi dependente desse fator.

No estudo de PONTORIERO; CARNEVALE ${ }^{49}$ (2001), quando a MG do retalho foi posicionada, em média de $2,1 \mathrm{~mm}$ apical à crista óssea, deixando osso alveolar proximal totalmente exposto, o maior crescimento coronal da MG ocorreu no primeiro mês, em média de $2,1 \mathrm{~mm}$, ou seja, $66 \%$ do crescimento coronal obtido aos 12 meses. No presente estudo, a MG do retalho foi posicionada, em média, 2,43mm e 2,34mm coronal ao nível ósseo, respectivamente, para sítios $M$ e $D$ (fase cirúrgica - Tabela 5.14). Um crescimento médio coronal de apenas $0,26 \mathrm{~mm}$ (sítios $M$ ) e 0,24mm (sítios D) foi observado no primeiro mês (Tabela 5.16), representando $18 \%$ e $15 \%$ do crescimento coronal obtido aos 12 meses. Ainda, uma alteração da MG também foi observada nos sítios $M$ e $D$ a partir do primeiro mês pós-cirúrgico, 
com migração coronal significante de $0,49 \mathrm{~mm}-0,56 \mathrm{~mm}$ entre período de 1-3 meses, de 0,39mm-0,37mm entre 3-6 meses e de 0,27mm-0,41mm entre 6-12 meses (Tabela 5.16), aproximando-se dos resultados de PONTORIERO; CARNEVALE $^{49}$ (2001), com valores médios de $0,4 \mathrm{~mm}, 0,4 \mathrm{~mm}$ e $0,3 \mathrm{~mm}$, respectivamente. Isso demonstrou que sítios proximais com retalho posicionado apicalmente à crista óssea apresentaram uma migração coronal da MG maior no primeiro mês do que nos meses subseqüentes, cuja magnitude de migração foi maior do que nos sítios com retalho reposicionado coronal à crista óssea.

O padrão no comportamento da $M G$ nos sítios $V$ e $L$ e sua magnitude foram totalmente dependentes do nível do retalho pós-sutura em relação à crista óssea. No estudo de PONTORIERO; CARNEVALE ${ }^{49}$ (2001), onde as margens dos retalhos foram posicionados, em média, 0,1 $\mathrm{mm}$ apical à crista óssea, observou-se uma tendência de crescimento coronal similar aos sítios proximais, com migração acentuada no primeiro mês, em média, de $1,6 \mathrm{~mm}$ ( $55 \%$ do crescimento coronal observado aos 12meses). Posteriormente, um crescimento médio coronal de $0,5 \mathrm{~mm}, 0,4 \mathrm{~mm}$ e $0,4 \mathrm{~mm}$ foi observado entre períodos de 1-3 meses, 3-6meses e 6-12meses, respectivamente. Da mesma forma como nos sítios proximais, sítios $\mathrm{V}$ e $\mathrm{L}$ com retalho posicionado ao nível ou apicalmente à crista óssea apresentaram uma migração coronal da MG maior no primeiro mês do que nos meses subseqüentes.

Esse comportamento coronal da MG não foi encontrado nos sítios $\mathrm{V}$ e $\mathrm{L}$ do presente estudo. As margens dos retalhos foram suturadas e posicionadas, em média, 2,50mm (sítios V) e 2,38mm (sítios L) coronal à crista óssea (fase cirúrgica - Tabela 5.14). A partir deste nível, a MG dos sítios $\mathrm{V}$ mostrou uma tendência para migração apical que foi estatisticamente significante aos 2 meses de avaliação (Tabela 5.15), média de 0,40mm (Tabela 5.16). Após esse período houve uma tendência gradual de migração coronal, permitindo que a MG aos 12 meses atingisse o nível estabelecido após sutura dos retalhos. Para os sítios L, a MG apresentou um discreto crescimento coronal que foi estatisticamente significante aos 4 meses (Tabela 5.15), com migração média de $0,24 \mathrm{~mm}$ (Tabela 5.16) quando comparado ao nível pós- 
sutura. Em relação ao período de 12 meses, as medidas de MG nos sítios $\mathrm{V}$ e L não apresentaram alterações estatisticamente significantes a partir do $4^{\circ}$ mês. A quantidade média de migração coronal da $M G$ foi de $-0,17 \mathrm{~mm}$ e 0,16mm entre período de 1-3 meses, de 0,13mm e 0,12mm entre 3-6 meses e de $0,17 \mathrm{~mm}$ e $0,23 \mathrm{~mm}$ entre $6-12$ meses, respectivamente, nos sítios $V$ e $\mathrm{L}$ (Tabela 5.16).

DEAS et al. ${ }^{18}$ (2004) apresentaram de forma agrupada os resultados de cada um dos sítios examinados e observaram uma migração coronal da MG, em média, de $0,36 \mathrm{~mm}$ no primeiro mês, com crescimento médio de 0,12mm entre período de 1-3 meses e 0,12mm entre 3-6 meses, nos sítios em que a posição do retalho variou de apical $a \geq 4 \mathrm{~mm}$ coronal à crista óssea. Pelo estudo de PONTORIERO; CARNEVALE ${ }^{49}$ (2001), pode-se calcular que a alteração média da MG de todos os sítios foi de $0,4 \mathrm{~mm}$ para coronal, entre 3 a 6 meses. No mesmo intervalo de tempo, a média total de migração coronal, calculada a partir dos dados da Tabela 5.16 , foi de $0,25 \mathrm{~mm}$.

Um comportamento totalmente diferente da MG foi relatado em 2 estudos clínicos, utilizando a técnica do retalho posicionado apicalmente com ressecção óssea. No estudo de LANNING et al. ${ }^{35}$ (2003), uma alteração média da MG de $0,26 \mathrm{~mm}$, estatisticamente não significante, foi relatada em direção apical entre 3 e 6 meses após cirurgia. DEAS et al. ${ }^{12}$ (2004) sugeriram que esse comportamento estável da MG (de 7,64mm para $7,90 \mathrm{~mm}$ ), incomum para sítios com retalho posicionado ao nível da crista óssea, poderia ser atribuído à quantidade de RO, média de 2,68mm. Porém, como a primeira medida clínica pós-cirúrgica foi realizada somente aos 3 meses, os autores ${ }^{35}$ não registraram a maior migração coronal da MG que ocorre no primeiro mês de reparação, característica do retalho posicionado apicalmente ${ }^{49}$. E em outro estudo, BRÄGGER; LAUCHENAUER; LANG ${ }^{12}$ (1992) observaram, a partir da MG do retalho suturado, uma migração média apical da $M G$ de $0,15 \mathrm{~mm}(7,49 \mathrm{~mm})$ após 6 semanas, seguida de uma migração coronal de 0,05mm (7,39mm) aos 6 meses, aproximando-se do nível da MG pós-sutura $(7,34 \mathrm{~mm})$. Segundo PONTORIERO; CARNEVALE ${ }^{49}$ (2001), diferenças na interpretação e/ou execução da técnica cirúrgica poderia ter ocorrido nesse estudo. 


\section{2) Aumento de coroa clínica aparente}

O aumento de coroa clínica é obtido pela ressecção óssea, deslocando o nível ósseo apicalmente; e o aumento de coroa clínica aparente é obtida pela ressecção gengival ou deslocando a MG apicalmente. Segundo INGBER; ROSE; $\operatorname{COSLET}^{29}$ (1977), o aumento de coroa clínica aparente obtido após sutura apical do retalho seria reduzido durante processo de reparo devido à migração coronal da MG para restabelecer uma nova unidade gengival supra-óssea, corroborando com os achados clínicos dos estudos de DEAS et al. ${ }^{18}$ (2004), PONTORIERO; CARNEVALE ${ }^{49}$ (2001) e neste estudo.

Como relatado previamente para sítios $\mathrm{M}$ e $\mathrm{D}$, a tendência da $\mathrm{MG}$ de migrar coronalmente a partir do nível pós-sutura, independente da posição do retalho em relação à crista óssea, resultou num aumento de coroa clínica aparente aos 12 meses menor do que aquele obtido após sutura. No estudo de PONTORIERO; CARNEVALE ${ }^{49}$ (2001), um aumento de coroa clínica aparente de $3,7 \mathrm{~mm}$ obtido após sutura do retalho, com exposição óssea proximal, foi reduzido significantemente para $0,5 \mathrm{~mm}$ aos 12 meses. Na Tabela 5.17, podese observar que o aumento de coroa clínica aparente pós-sutura coronal do retalho também reduziu significantemente de $2,03 \mathrm{~mm}$ para $0,52 \mathrm{~mm}$ nos sítios M e de 2,23mm para $0,74 \mathrm{~mm}$ nos sítios $D$.

$\mathrm{O}$ aumento de coroa clínica aparente pós-sutura nos sítios $\mathrm{V}$ e $\mathrm{L}$, relatado por PONTORIERO; CARNEVALE ${ }^{49}$ (2001), apresentou o mesmo comportamento que os sítios proximais. Houve um aumento médio de coroa clínica aparente de $4,1 \mathrm{~mm}$, que reduziu significantemente para $1,2 \mathrm{~mm}$ aos 12 meses. No presente estudo, como as alterações na $M G$ nos sítios $V$ e $L$ foram menores durante período de reparação, a diferença entre os valores médios do aumento médio de coroa clínica aparente obtido após sutura dos retalhos e aos 12 meses foi menor que $0,5 \mathrm{~mm}$ (Tabela 5.17). O aumento médio de coroa clínica aparente ao final do estudo foi de 1,39mm nos sítios $V$ e de $1,23 \mathrm{~mm}$ nos sítios L. No estudo de BRÄGGER; LAUCHENAUER; LANG ${ }^{12}$ (1992), onde a MG apresentou-se estável, o aumento médio da coroa clínica aparente de $1,32 \mathrm{~mm}$ obtido após sutura também foi similar aos 6 meses $(1,37 \mathrm{~mm})$. 


\section{3) Tecido gengival supra-ósseo}

A medida média de $2,04 \mathrm{~mm}$ para distância biológica compreende a soma de $1,07 \mathrm{~mm}$ da inserção conjuntiva e $0,97 \mathrm{~mm}$ do epitélio juncional. Contudo essas medidas representam a média total dos valores obtidos por GARGIULO; WENTZ; ORBAN ${ }^{23}$ (1961) em quatro fases diferentes da posição do epitélio juncional (porção mais apical) em relação à junção cemento-esmalte. $\mathrm{Na}$ Tabela 6.1, estão apresentados os valores médios dos sítios $M, V, L$ e D sem alteração no nível de inserção (porção mais apical do epitélio juncional coincidindo com a junção cemento-esmalte), referente à primeira fase. Dessa forma, para sítios sem alteração no nível de inserção clínica, a medida da distância biológica corresponderia ao valor de 2,43mm, com medida do epitélio juncional variando de 0,28 a 3,72mm (média de 1,35mm) e inserção conjuntiva, de $0,04 \mathrm{~mm}$ a $3,36 \mathrm{~mm}$ (média de $1,08 \mathrm{~mm}$ ). Por isso, ao estabelecer medidas médias fixas para distância biológica menospreza-se sua variabilidade entre dentes e entre superfícies ao redor do mesmo dente ${ }^{16,22,39,61}$. Apesar desse conhecimento, INGBER; ROSE; $\operatorname{COSLET}^{29}$ (1977) determinaram uma medida média com o intuito de estabelecer uma base para decisões clínicas.

TABELA 6.1 - Valores médios das medidas de sulco gengival, epitélio juncional, inserção conjuntiva, distância biológica e tecido gengival supra-ósseo nos sítios $M, V, L$ e $D$, e média total, em dentes com nível de inserção igual a zero (primeira fase), em milímetros ${ }^{23}$.

\begin{tabular}{lccccc}
\hline & Sítio M & Sítio V & Sítio L & Sítio D & Média \\
\hline Sulco gengival (a) & 1,09 & 0,87 & 0,40 & 0,84 & 0,80 \\
Epitélio juncional (b) & 1,56 & 1,35 & 1,14 & 1,37 & 1,35 \\
Inserção conjuntiva (c) & 0,75 & 1,01 & 1,49 & 1,10 & 1,08 \\
\hline Distância biológica (b+c) & 2,31 & 2,36 & 2,63 & 2,47 & 2,43 \\
\hline Tecido supra-ósseo (a+b+c) & 3,40 & 3,23 & 3,04 & 3,31 & 3,23 \\
\hline
\end{tabular}


Baseando-se na variabilidade, LANNING et al. $^{35}$ (2003) preconizaram um método clínico de obtenção da medida da distância biológica pela subtração da medida do nível ósseo (distância da placa de referência até crista óssea) e do nível de inserção (distância da placa de referência até fundo do sulco gengival clínico) para cada sítio, previamente à cirurgia. A quantidade de RO a ser realizada em cada sítio baseou-se nessa medida. A medida média da distância biológica pré-cirúrgica de 2,26mm foi restabelecida aos 6 meses $(2,19 \mathrm{~mm})$ nos sítios tratados. Essa medida clínica definida por LANNING et al. ${ }^{35}$ (2003) como distância biológica, não representa a real dimensão vertical do epitélio juncional e inserção conjuntiva, como observada microscopicamente. BLOCK $^{11}$ (1987), também declarou que a determinação clínica da medida real da distância biológica pelo profissional é difícil e sugeriu que a margem gengival estável e saudável fosse utilizada como ponto de referência para diversos procedimentos clínicos, como por exemplo, localização da margem de uma restauração. Da mesma forma, NEVINS; SKUROW ${ }^{42}$ (1984) declararam que não é possível a localização clínica do limite entre sulco gengival e epitélio juncional. Concordando com esses autores, KOIS ${ }^{32}$ (1994) preconizou a utilização clínica de todo complexo gengival, ou seja, da margem gengival até crista óssea, sendo mais exata do que apenas a medida da distância biológica.

O complexo gengival localizado supra-ósseo foi denominado por SMUKLER; $\mathrm{CHAIBI}^{61}$, em 1997, de tecido gengival supra-ósseo (TGS). Esses autores preconizaram a obtenção da medida de TGS individualmente para cada sítio de um dente, previamente à excisão cirúrgica, sugerindo que esta medida poderia ser restabelecida ao final do processo de reparo. KOIS; VALKAY ${ }^{33}$, em 2000, sugeriram a obtenção da medida clínica de TGS por meio de uma sonda periodontal introduzida no sulco gengival até atingir a crista óssea.

Nesta investigação clínica, as medidas médias de TGS obtidas previamente à cirurgia foram de $3,48 \mathrm{~mm}$ para sítios $\mathrm{M}$ e de $3,40 \mathrm{~mm}$ para sítios $\mathrm{D}$ (Tabela 5.14). Após sutura dos retalhos reposicionados coronal à crista óssea, essas medidas reduziram significantemente para 2,43mm e 2,34mm, respectivamente, para sítios $M$ e $D$. Para reformar a medida de TGS, houve 
migração coronal da $M G$ durante todo período de reparação (Figura 5.2), alcançando as medidas médias pré-cirúrgicas de TGS aos 6 meses, tanto nos sítios $M(3,48 \mathrm{~mm})$ como nos sítios $D(3,44 \mathrm{~mm})$. Aos 12 meses, as medidas médias de TGS foram de 3,88mm (sítios M) e 3,84mm (sítios D), sendo esse aumento estatisticamente significante apenas para sítios $M$. Esse comportamento do TGS também foi observado no estudo de PONTORIERO; CARNEVALE $^{49}$ (2001). Mediante os dados de MG inicial, pós-sutura e final e NO pré e pós-osteotomia relatados nesse estudo, as medidas de TGS précirúrgica, pós-sutura, 6 meses e 12 meses foram calculadas, obtendo-se valores médios de $2,8 \mathrm{~mm},-2,1 \mathrm{~mm}, 2,9 \mathrm{~mm}$ e $3,2 \mathrm{~mm}$ para sítios proximais, respectivamente. A medida de TGS aos 12 meses foi $0,4 \mathrm{~mm}$ maior do que a medida pré-cirúrgica, tanto neste estudo como no estudo de PONTORIERO, CARNEVALE $^{49}$ (2001). No presente estudo, a medida pré-cirúrgica de TGS foi realizada em sítios com inflamação devido à invasão do espaço da distância biológica, o que resultou numa altura menor do que TGS pós-cirúrgico. OAKLEY et al. ${ }^{43}$ (1999) utilizaram medidas pré-cirúrgicas de TGS obtidas em sítios saudáveis e normais, no dente a ser tratado ou dente contralateral.

Como a medida média de TGS cirúrgica foi igual à medida précirúrgica $(2,51 \mathrm{~mm})$ nos sítios $\vee$ (Tabela 5.14 ), as alterações na MG foram mínimas, sem diferença estatisticamente significante entre a posição da MG pós-sutura e aos 12 meses (Tabela 5.15); confirmando que a medida précirúrgica de TGS tende a ser restabelecida após cirurgia. Para os sítios $L$ com discreta migração coronal da MG, as medidas médias de TGS pré-cirúrgica e pós-sutura foram de $3,05 \mathrm{~mm}$ e $2,38 \mathrm{~mm}$, respectivamente. A medida de TGS aos 12 meses foi menor do que a medida pré-cirúrgica, em média, $0,16 \mathrm{~mm}$ (sítios $V$ ) e $0,19 \mathrm{~mm}$ (sítios $L$ ), sem diferença estatisticamente significante. No estudo de PONTORIERO, CARNEVALE ${ }^{49}$ (2001), as medidas médias de TGS pré-cirúrgica, pós-sutura, 6 meses e 12 meses foram calculadas em 3,1mm, $0,1 \mathrm{~mm}, 2,5 \mathrm{~mm}$ e $2,9 \mathrm{~mm}$, respectivamente, para sítios V/L. A medida de TGS aos 12 meses também foi menor $(0,2 \mathrm{~mm})$ do que a medida pré-cirúrgica.

Nas reavaliações clínicas de 6 e 12 meses, a medida de NO pósosteotomia foi utilizada como referência para obtenção das medidas de TGS 
(Tabela 5.14), conforme estudo de VAN DER VELDEN ${ }^{67}$ (1982), uma vez que a sondagem transgengival poderia interferir na reparação do tecido gengival marginal.

A partir das medidas de MG e NO relatadas por LANNING et al. ${ }^{35}$ (2003), as medidas médias calculadas para TGS foram de 4,76mm antes da cirurgia, 5,14mm após 3 meses e 4,93mm após 6 meses. Pela análise das medidas de TGS, foi possível compreender porque o comportamento da MG no estudo de LANNING et al. ${ }^{35}$ (2003) diferiu dos outros estudos ${ }^{12,18,49}$. De fato, a migração apical da MG de 0,26mm observada entre períodos de 3 e 6 meses correspondeu à reformação de TGS.

Os valores médios pré-cirúrgicos de TGS apresentados na Tabela 5.14 foram similares àqueles obtidos por GARGIULO; WENTZ; ORBAN ${ }^{23}$ (1961) (Tabela 6.2) nos sítios $M, L$ e D, a partir da análise de vários grupos dentários. Nos sítios $\mathrm{V}$, a medida média de TGS de 2,51mm foi menor do que aquela encontrada por GARGIULO; WENTZ; ORBAN ${ }^{23}$ (3,23mm), aproximando-se de MENDONÇA ${ }^{40}$ (2001), com média de 2,28mm (pré-molares e molares).

KOIS; VALKAY ${ }^{33}$, em 2000, relataram que medidas de TGS são menores para faces livres do que para faces proximais (na presença de dente adjacente), cerca de $3,0 \mathrm{~mm}$ e $4,0 \mathrm{~mm}$, respectivamente. Contudo, as medidas de TGS registradas por COESTA $^{16}$ (2003), em dentes pré-molares com periodonto normal e saudável, foram maiores, em média, 4,55mm (sítios $M$ ), 3,78mm (sítios V), 3,94mm (sítios L) e 4,27mm (sítios D). PEREZ ${ }^{48}$ (2003) observou radiograficamente nos sítios $\mathrm{M}$ dos primeiros $\mathrm{PM}$ superiores, uma altura média do espaço interdentário (distância entre contato proximal e crista óssea) de 4,61mm. Esses valores médios também foram encontrados em áreas após cirurgia. VAN DER VELDEN ${ }^{67}$ (1982) observou um crescimento gengival médio de 4,33mm 3 anos após tratamento de áreas com perda óssea, a partir do nível ósseo proximal exposto após sutura do retalho (Tabela 6.2).

TABELA 6.2 - Medidas médias (desvios padrão) do tecido gengival supraósseo (análise clínica ou microscópica) e da altura do espaço interdentário 
(análise radiográfica) nos sítios mesial (M), vestibular (V), lingual (L) e distal (D), de acordo com as informações colhidas na literatura.

\begin{tabular}{|c|c|c|c|c|c|c|c|}
\hline & \multirow{2}{*}{$\begin{array}{c}\text { Grupo } \\
\text { dentário }\end{array}$} & \multirow{2}{*}{$\begin{array}{l}\text { Idade } \\
\text { (anos) }\end{array}$} & \multirow{2}{*}{ Análise } & \multicolumn{4}{|c|}{ Sítios } \\
\hline & & & & $\mathbf{M}$ & $\mathbf{V}$ & $\mathbf{L}$ & D \\
\hline $\begin{array}{l}\text { Gargiulo } \\
\text { et al. }{ }^{23} \\
(1961)\end{array}$ & Todos & 19 a 43 & microscópica & 3,40 & 3,23 & 3,03 & 3,31 \\
\hline $\begin{array}{l}\text { Van de } \\
\text { Velden } \\
\text { (1982) }\end{array}$ & & & clínica & $\begin{array}{c}4,33 \\
(0,94)\end{array}$ & & & $\begin{array}{l}4,33 \\
(0,94)\end{array}$ \\
\hline $\begin{array}{l}\text { Mendonça }{ }^{40} \\
\text { (2001) }\end{array}$ & $\begin{array}{l}\text { Pré- } \\
\text { molar e } \\
\text { molar }\end{array}$ & & clínica & & $\begin{array}{c}2,28 \\
(1,12)\end{array}$ & & \\
\hline $\begin{array}{l}\text { Coesta }^{16} \\
(2003)\end{array}$ & $\begin{array}{l}\text { Pré- } \\
\text { molar }\end{array}$ & & clínica & 4,55 & 3,78 & 3,94 & 4,27 \\
\hline $\begin{array}{l}\text { Perez }^{48} \\
(2003)\end{array}$ & $\begin{array}{l}\text { Pré- } \\
\text { molar }\end{array}$ & 20 a 50 & radiográfica & $\begin{array}{c}4,61 \\
(0,62)\end{array}$ & & & \\
\hline
\end{tabular}

Como as medidas clínicas de TGS nos sítios proximais de prémolares têm sido relatadas com valores médios maiores que $4,2 \mathrm{~mm}^{16,67}$, podese esperar mais migração coronal da MG proximal, uma vez que os valores médios encontrados aos 12 meses foram de $3,88 \mathrm{~mm}$ e $3,84 \mathrm{~mm}$. A tendência do gráfico na Figura 5.1 mostra que a estabilização da MG nos sítios M e D ocorrerá após 12 meses. 


\section{4) Quantidade de ressecção óssea}

A distância mínima de $3 \mathrm{~mm}$ de estrutura dentária entre TC e crista óssea sugerida por INGBER; ROSE; COSLET ${ }^{29}$ (1977), tem sido amplamente preconizada por outros autores ${ }^{9,38,42}$, possibilitando execução de procedimentos restauradores e manutenção da saúde periodontal a longo prazo. Por meio da literatura, observa-se que outras medidas têm sido sugerida para distância entre TC e crista óssea, como 2,5 a 3,5 mm $\mathrm{mb}^{46}, 3,0$ a 4,0 $\mathrm{mm}^{22}, 3,5$ a $4,0 \mathrm{~mm}^{6}, 4 \mathrm{~mm}^{16,58}$ e 5,0 a $5,5 \mathrm{~mm}^{69}$. Neste estudo, a $\mathrm{RO}$ foi realizada para obter uma distância mínima de $3 \mathrm{~mm}$ entre TC e crista óssea proximal (Tabela 5.7). Para os casos de coroa clínica curta, a RO foi executada para obter um aumento de coroa adequada para retenção protética, buscando harmonizar-se com o nível ósseo dos dentes adjacentes.

O nível de TC estabelecido durante a fase cirúrgica (antes da ressecção óssea) permaneceu inalterado por todo período de avaliação. Esse mesmo cuidado foi tomado por HERRERO et al. ${ }^{28}$ (1995) para excluir a influência de fatores relacionados aos procedimentos restauradores na reparação dos tecidos periodontais marginais. Diferente da maioria dos estudos encontrados na literatura ${ }^{12,18,19,35}$, onde tratamentos restauradores definitivos foram iniciados antes da finalização do estudo.

Os TC supragengivais estavam localizados $0,77 \mathrm{~mm}$ e $0,86 \mathrm{~mm}$ subgengivalmente ao final de 12 meses (Tabela 5.13); caso necessite que o TC se localize supragengivalmente ao final do processo de reparo, a quantidade de RO deverá ser maior, para obter uma distância entre TC e crista óssea maior do que a medida pré-cirúrgica de TGS. Isso está de acordo com VAN DER VELDEN ${ }^{67}$ (1982), que após formação média de 4,33mm do TGS (Tabela 6.2), sugeriu uma distância de $5 \mathrm{~mm}$ de estrutura dentária entre TC e crista óssea proximal para localizar o TC supragengival após estabilização da MG. Portanto, a ressecção óssea deve ser baseada na medida de tecido gengival supra-ósseo individual para cada sítio, e não na medida fixa de $3 \mathrm{~mm}$ (baseada na medida da distância biológica), além de considerar o nível do TC desejado após reparação tecidual. 


\section{5) Posição da margem do retalho pós-sutura em relação à crista}

óssea

A migração coronal média da $M G$ de todos os sítios foi de $0,57 \mathrm{~mm}$ aos 6 meses e de 0,84mm aos 12 meses, a partir do nível do retalho suturado, em média, 2,41 mm coronal à crista óssea. DEAS et al. ${ }^{18}$ (2004) apresentaram migração média coronal de $0,70 \mathrm{~mm}$ aos 6 meses, sendo que a posição do retalho variou de 0 a $\geq 4 \mathrm{~mm}$ coronal à crista óssea. E PONTORIERO; CARNEVALE $^{49}$ (2001) observaram uma migração coronal média de $2,7 \mathrm{~mm}$ aos 6 meses e 3,0mm aos 12 meses, para sítios com retalho posicionado de $0,1 \mathrm{~mm}$ a $2,1 \mathrm{~mm}$ apicalmente à crista óssea. A análise comparativa desses resultados demonstrou que retalho posicionado e suturado ao nível ou apical à crista óssea ${ }^{49}$ apresenta maior quantidade de migração coronal da MG em relação ao retalho reposicionado e suturado coronal à crista óssea ${ }^{18, \text { presente estudo }}$.

Esse comportamento também foi verificado entre os sítios do mesmo estudo. De acordo com a Tabela 5.18, observa-se que a migração média da MG em direção coronal foi de $1,16 \mathrm{~mm}$ nos sítios com retalho posicionado até $1 \mathrm{~mm}$ coronal à crista óssea. Para os retalhos posicionados $2 \mathrm{~mm}$ e $3 \mathrm{~mm}$ coronal à crista óssea, a quantidade de migração coronal da MG foi menor, respectivamente, de $0,85 \mathrm{~mm}$ e $0,77 \mathrm{~mm}$. Nos sítios com retalho posicionado a $4 \mathrm{~mm}$ da crista óssea, a MG migrou 0,06 mm para apical. Similarmente, DEAS et al. $^{18}$ (2004) verificaram que sítios tratados com retalho posicionado até $1 \mathrm{~mm}$, $2 \mathrm{~mm}, 3 \mathrm{~mm}$ e $\geq 4 \mathrm{~mm}$ coronal à crista óssea apresentaram alteração média de 1,25mm, 0,84mm, 0,58mm e -0,12mm, respectivamente. Dessa forma, a migração da MG em direção coronal ou apical após cirurgia representou uma tendência dos tecidos periodontais de reformar a medida pré-cirúrgica de TGS. Os autores confirmaram a existência de uma correlação inversa significante ($0,422, p<0,01)$ entre a distância do retalho à crista óssea no momento da sutura e a quantidade de migração da MG após 6 meses, indicando maior migração coronal quanto maior a proximidade da margem do retalho em relação à crista óssea. Da mesma forma, uma correlação inversa estatisticamente significante entre essas duas variáveis foi observada nos sítios $M(r=-0,43, p<0,05)$ e $L(r=-0,41, p<0,05)$ aos 6 meses (Tabela 5.19). Contudo, 
no período de 12 meses, nenhum sítio demonstrou correlação inversa significante entre quantidade de migração da MG e posição do retalho póssutura em relação à crista óssea.

A técnica do retalho de espessura total reposicionado coronal à crista óssea tem sua principal indicação em dentes com envolvimento estético e que serão reabilitados proteticamente, por manter o retalho próximo ao nível do término cervical ${ }^{69,70}$, reduzindo a exposição radicular na fase pós-cirúrgica imediata e no primeiro mês de controle pós-operatório.

Assim, quando a técnica de retalho for executada na cirurgia de aumento de coroa, a localização da futura MG em relação ao nível ósseo pósosteotomia deve ser baseada no conceito de tecido gengival supra-ósseo individual para cada sítio, e não no conceito de distância biológica ${ }^{70}$, com medidas médias fixas para todos os sítios ao redor de dentes de diferentes grupos.

\section{6) Espessura gengival}

A influência da espessura gengival na alteração do nível da MG foi relatada no estudo de PONTORIERO \& CARNEVALE $^{49}$ (2001). Um crescimento coronal médio significante de $3,6 \pm 0,5 \mathrm{~mm}$ (sítios proximais) e $3,1 \pm 0,8 \mathrm{~mm}$ (sítios $\mathrm{V} / \mathrm{L}$ ) foram observados para pacientes com biotipo tecidual espesso e 2,8 $\pm 0,7 \mathrm{~mm}$ (sítios proximais) e 2,6 $\pm 0,4 \mathrm{~mm}$ (sítios V/L) para pacientes com biotipo fino. Os autores utilizaram a classificação de gengiva normal, fina e espessa, preconizada por SEIBERT; LINDHE61 (1989).

A medida da espessura gengival vestibular ao pré-molar foi realizada previamente à cirurgia com auxílio de agulha anestésica e cursor endodôntico. Após mensuração, espessura $\leq 1,5 \mathrm{~mm}$ foi considerada como gengiva fina e espessura $>1,5 \mathrm{~mm}$, como gengiva espessa, de acordo com a classificação proposta por CLAFFEY; SHANLEY ${ }^{14}$ (1986). Na amostra, 9 dentes pré-molares foram encontrados com gengiva espessa (espessura média de 1,74mm) e 21 pré-molares com gengiva fina (espessura média de 1,22mm) (Tabela 5.20). 
Nenhuma correlação estatisticamente significante foi observada entre alteração da MG e espessura gengival. A distribuição da amostra, espessura do retalho e classificação da espessura gengival empregada podem ter influenciado os resultados do presente estudo.

Dessa forma, diversos fatores podem influenciar a magnitude e extensão das alterações na MG durante processo de reparo, como resposta individual $^{18,49}$, espessura do retalho, reformação de $\operatorname{TGS}^{18}$, posição do retalho pós-sutura $^{12,18}$, arquitetura óssea obtida após ressecção óssea ${ }^{18}$, espessura gengival $^{49,74}$, controle de placa $^{18,67}$, tempo de avaliação $^{18,49,61}$, superfície/dente/área tratada ${ }^{28,70}$, técnica cirúrgica empregada ${ }^{28,74}$, habilidade profissional $^{28,49}$ e início dos procedimentos retauradores ${ }^{18}$. Além disso, o contorno gengival pode ser influenciado pela anatomia da superfície dentária e da configuração óssea subjacentes ${ }^{61,70}$.

\section{7) Tempo mínimo para iniciar os procedimentos restauradores}

O período de tempo empregado para avaliação da MG após cirurgia de aumento de coroa com finalidade restauradora variou de 2 meses $^{28}, 3$ meses $^{43}, 6$ meses $^{12,18,35}$ e 12 meses $^{49}$. PONTORIERO; CARNEVALE ${ }^{49}$ (2001) observaram migração coronal da $M G$ nos sítios $\mathrm{V} / \mathrm{L}$, com tendência de estabilizar-se após 12 meses da cirurgia. De acordo com os dados das Tabelas 5.15, as medidas de MG nos sítios $V$ e $L$ apresentaram-se estatisticamente estáveis entre 4 e 12 meses. Comparando os resultados desses dois estudos clínicos de 12 meses, pode-se sugerir que sítios com retalhos reposicionados coronal à crista óssea, próximos à medida pré-cirúrgica de TGS, requerem um menor período de tempo para a estabilização da MG quando comparado ao retalho posicionado ao nível da crista óssea, corroborando com as experiências clínicas de DEAS et al. ${ }^{18}$ (2004), WAGENBERG ${ }^{69}$ (1998) e WAGENBERG; ESKOW; LANGER ${ }^{70}$ (1989). Para sítios M e D, a tendência de estabilização da MG após 12 meses foi verificada por PONTORIERO; CARNEVALE ${ }^{49}$ (2001) e por este estudo (Tabela 5.15 e Figura 5.1). SMUKLER; CHAIBI ${ }^{61}$ (1997) declararam que se o TC for delimitado intra-sulcular antes de um ano pós- 
cirúrgico, o mesmo se localizará num nível mais subgengival. Dessa forma, a estabilidade da MG deve ser confirmada por meio de um monitoramento clínico mensal, particularmente em áreas estéticas ${ }^{12,35,74}$. Segundo WISE $^{74}$ (1985), o repreparo do TC deveria ser realizado somente quando a posição da MG estivesse estabilizada por pelo menos um mês (2 medidas consecutivas). Os dados da Tabela 5.15 demonstram que esse método não permite determinar a posição estável da MG.

A partir de todos os aspectos discutidos previamente, pode-se estabelecer um método clínico hipotético que permita ao profissional determinar a estabilidade da MG (Figura 6.1 e 6.2). Este método consiste em obter a medida pré-cirúrgica de TGS, definir um ponto de referência fixo e medir a distância entre TC e crista óssea.

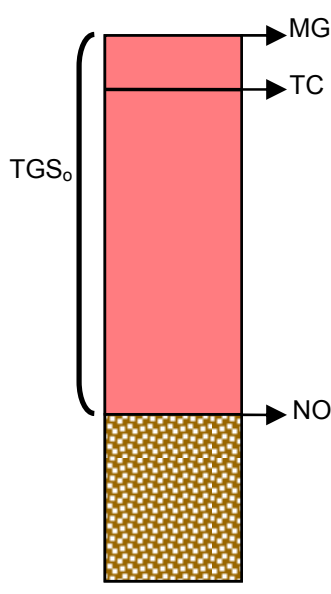

Fase pré-cirúrgica

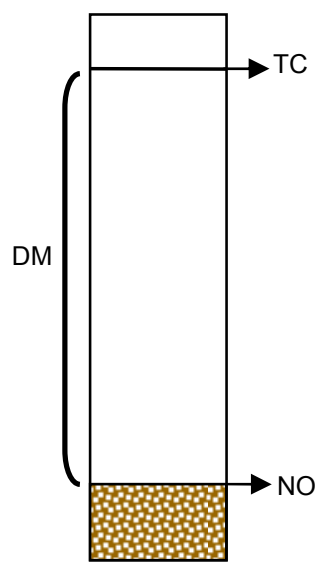

Fase pós-osteotomia

FIGURA 6.1 - Desenho esquemático das medidas clínicas. A medida do tecido gengival supra-ósseo (TGS $)$, desde a margem gengival (MG) até nível ósseo (NO), é obtida previamente à cirurgia . Após definição do término cervical (TC), como ponto de referência fixo, e ressecção óssea, a medida do TC até NO (distância mínima - DM) é obtida antes da sutura do retalho. 
Em relação à medida pré-cirúrgica de TGS, deve ser obtida, sempre que possível, nos sítios saudáveis e normais ao redor do dente a ser tratado ou contralateral, após anestesia realizada distante da $\mathrm{MG}^{61}$. Uma sonda periodontal deve ser introduzida no sulco gengival e forçada até atingir a crista óssea, para obter a medida de TGS individualmente para cada sítio (fase précirúrgica - Figura 6.1).

A seleção do TC do preparo como ponto de referência fixo é o mais adequado. A sua delimitação pode ser realizada antes da cirurgia ou durante a mesma, previamente à ressecção óssea, e deve permanecer inalterado durante todo período pós-operatório ${ }^{28}$. Quando da escolha da junção cementoesmalte $(\mathrm{JCE})^{36}$, superfície oclusal ${ }^{49}$ ou marcações confeccionadas na coroa provisória ${ }^{74}$ como pontos de referência fixo, cuidados devem ser tomados para prevenir fratura da estrutura dentária remanescente, evitar perda ou fratura da coroa provisória durante período de avaliação pós-cirúrgica, além das dificuldades clínicas para localizar a JCE.

Após o rebatimento de retalho total $V$ e $L$ e ressecção óssea, a distância entre TC e crista óssea (distância mínima - DM) é medida antes da sutura do retalho (Fase pós-osteotomia - Figura 6.1).

Assim, o cálculo da Posição Estável da Margem gengival (PEM) representa a diferença entre a medida pré-cirúrgica de TGS $\left(\mathrm{TGS}_{\mathrm{o}}\right)$ e da distância entre TC e crista óssea (DM):

\section{$\mathrm{PEM}=\mathrm{TGS}_{\mathrm{o}}-\mathrm{DM}$}

Um valor negativo para PEM representaria localização da futura $M G$ estável apical ao TC (A - Figura 6.2), e um valor positivo, localização da futura MG estável coronal ao TC (B - Figura 6.2). O valor de PEM pode ser calculado para sítios $\mathrm{M}, \mathrm{V}, \mathrm{L}$ e $\mathrm{D}$. 
Durante monitoramento clínico pós-cirúrgico, a medida de TC até MG registrada mensalmente para cada sítio, com sonda periodontal ${ }^{12}$, será comparada ao respectivo valor de PEM. A diferença entre medida de TC até MG e valor de PEM representa a quantidade de migração da MG que ocorrerá durante a reparação para reformar a medida de TGS. A igualdade entre eles demonstra que houve reformação de TGS; e a MG poderá ser considerada estável se essa posição for confirmada por pelo menos um mês ${ }^{74}$.

Na prática clínica diária, diversas dificuldades podem comprometer esse monitoramento clínico da MG ou impedir a espera do tempo mínimo necessário para iniciar os procedimentos restauradores definitivos. SMUKLER; $\mathrm{CHAIBI}^{61}$ (1997) sugeriram a possibilidade de repreparar o TC ligeiramente supragengival ou ao nível da MG de 3 a 6 meses após cirurgia, prevendo a ocorrência da migração coronal da MG, baseado na reformação da medida de TGS $^{22,29,35,42,55,70}$. Pelo método clínico PEM, o repreparo do TC no nível desejado pode ser realizado, utilizando a MG em reparação como ponto de referência fixo.

O método clínico PEM também pode ser empregado para determinar a futura MG no momento da sutura do retalho, como sugerido por BRÄGGER; LAUCHENAUER; LANG ${ }^{12}$ (1992) e como observado nos resultados apresentados na Tabela 5.15. Para atingir esse objetivo, a margem do retalho deve ser suturada coronal à crista óssea no nível da medida pré-cirúrgica de TGS. O primeiro passo refere-se à definição da futura $M G$ na face $V$ e $L$ do dente a ser tratado, por meio de uma incisão em bisel interno, que corresponda ao aumento de coroa clínica aparente desejado (Figura 6.3). Em seguida, essa incisão terminaria intra-sulcular nas faces proximais, estendendo-se aos dentes adjacentes para harmonizar a nova MG e para reproduzir um arco côncavo mais apicalmente. O aumento de coroa clínica aparente é verificado após remoção do "colar" de tecido gengival ao redor dos dentes. 


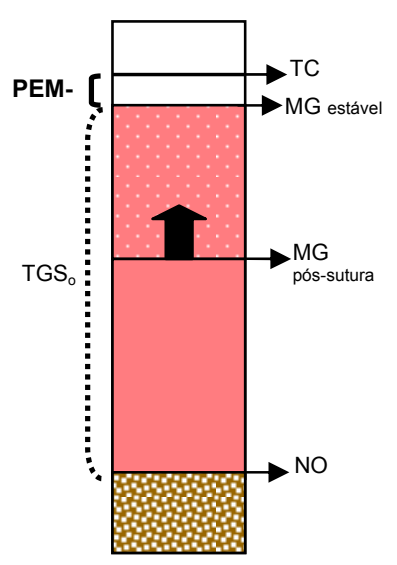

A

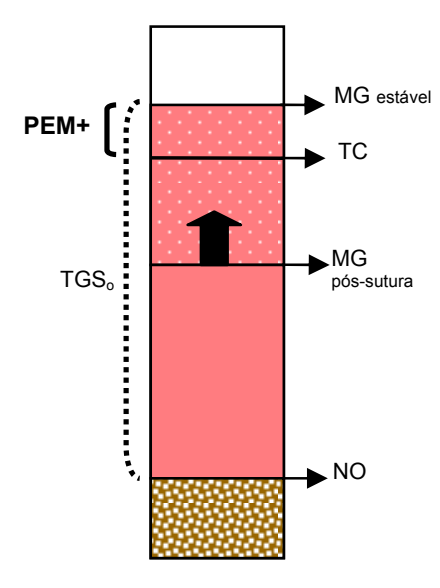

B

FIGURA 6.2 - Desenho esquemático da previsão da margem gengival estável (MG estável) em relação ao término cervical (TC). Esta previsão baseia-se na reformação da medida pré-cirúrgica do tecido gengival supra-ósseo (TGS $)$ sobre a superfície dentária coronalmente (seta larga) à margem do retalho suturado (MG pós-sutura). Um valor negativo (A) para Posição Estável da Margem (PEM) representaria localização final da MG apical ao término cervical (TC), e um valor positivo (B), localização da MG coronal ao TC. (NO - nível ósseo).

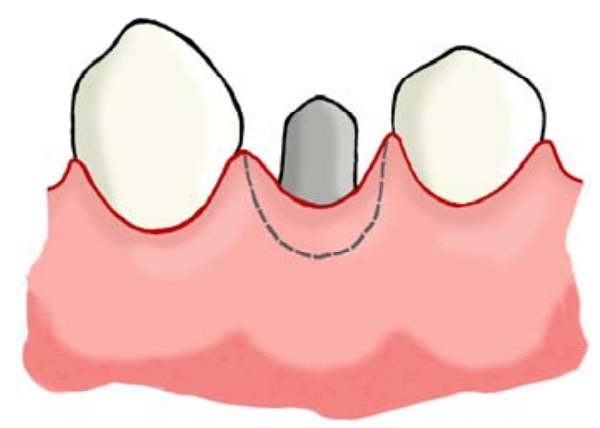

FIGURA 6.3 - Desenho esquemático da delimitação da nova e futura margem gengival com uma incisão em bisel interno na face vestibular do primeiro prémolar (linha tracejada), correspondendo ao aumento de coroa clínica aparente desejado.

Uma vez obtido o aumento de coroa clínica desejado, uma sonda periodontal deve ser forçada transgengivalmente até a crista óssea para obter 
uma medida que será comparada à medida pré-cirúrgica de TGS (Tabela 6.4). A diferença entre as medidas revela a quantidade de $\mathrm{RO}$ a ser realizada, e que deve ser registrada a partir do TC, antes do rebatimento dos retalhos totais. Após $\mathrm{RO}$, os retalhos são reposicionados e suturados, reproduzindo a medida pré-cirúrgica de TGS coronal à crista óssea (fase pós-sutura - Figura 6.4). Dessa forma, a quantidade de RO deve ser suficiente para restabelecer o espaço para formação do $\mathrm{TGS}^{61}$ individualmente para cada sítio, baseando-se também na localização do TC esperado ao final do processo de reparo (Figura 6.2). TC localizado supragengival após estabilização da MG requer uma maior quantidade de RO (distância do TC até crista óssea maior do que a medida pré-cirúrgica de TGS). Por este método PEM, o aumento da coroa clínica aparente nos sítios $\mathrm{V}$ e $\mathrm{L}$ torna-se mais previsível, como observado no presente trabalho.
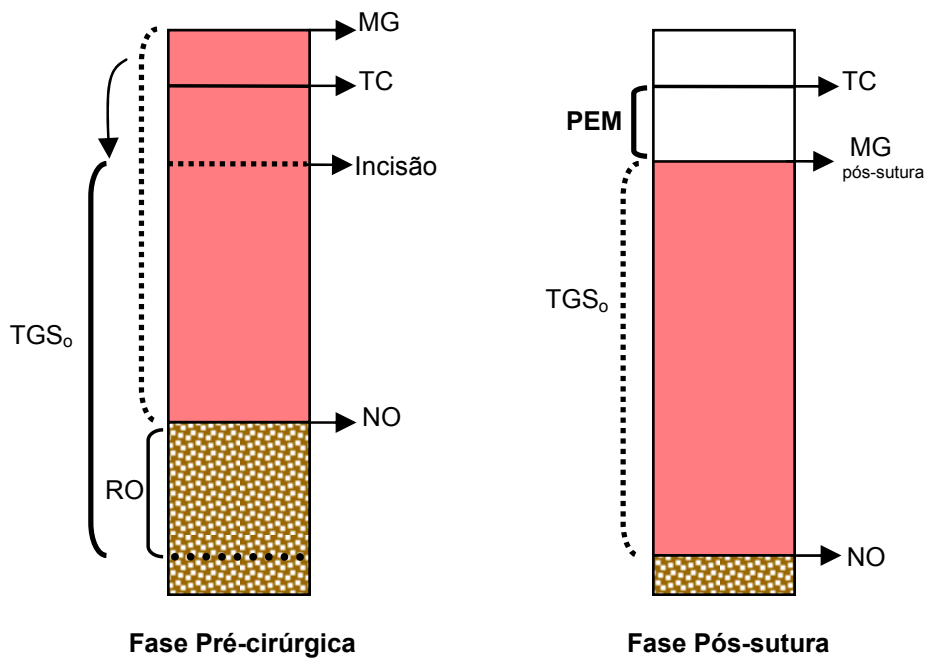

FIGURA 6.4 - Desenho esquemático da definição da futura margem gengival durante a cirurgia. Uma incisão em bisel interno determina a quantidade de aumento de coroa clínica aparente desejada. O restabelecimento (seta) da medida pré-cirúrgica do tecido gengival supra-ósseo $\left(\mathrm{TGS}_{\mathrm{o}}\right.$ ) entre nível da incisão e o nível ósseo (NO) determina a quantidade de ressecção óssea (RO) a ser realizada. Após reposicionamento e sutura do retalho (MG pós-sutura) coronal ao NO pósosteotomia, a previsão da posição estável da margem (PEM) pode ser monitorada periodicamente em relação ao término cervical (TC). (MG - margem gengival). 
Como a MG nos sítios $\mathrm{V}$ e $\mathrm{L}$ alcançou estabilidade mais precocemente do que a MG nos sítios $M$ e $D$ (Tabela 5.15), pode-se sugerir que formação completa da papila gengival seria um indicativo clínico da estabilidade dos tecidos periodontais marginais após cirurgia de aumento de coroa.

\section{8) Papila gengival}

A papila gengival ${ }^{26,72}(P G)$ (gengiva interdentária ${ }^{26}$ ou papila interdentária ${ }^{58}$ ou papila interproximal ${ }^{65}$ ) corresponde à gengiva localizada entre dois dentes contíguos, desde uma linha imaginária tangente ao contorno gengival mais apical até o vértice da margem gengival (formato triangular), quando observada numa vista vestibular ${ }^{10,44}$. Microscopicamente, a PG é formada por um tecido conjuntivo denso coberto pelo epitélio oral, externamente, e pelos epitélios juncional e sulcular, internamente. Esta constituição atua como uma barreira biológica protetora do periodonto de suporte subjacente e também, determina a estética dento-facial ${ }^{58}$.

A PG, quando preenche totalmente o espaço interdentário ${ }^{63}$ (ou espaço interproximal ${ }^{72}$ ), estende-se desde a crista óssea até contato proximal, e como conseqüência, estabelece arcos côncavos característicos da gengiva marginal livre ${ }^{26}$. WHEELER $(1965)^{72}$ descreveu o espaço interdentário entre dois dentes adjacentes em contato com forma triangular: base do triângulo representado pelo osso alveolar, lados do triângulo, pelas superfícies dentárias proximais, e vértice do triângulo, pelo contato proximal. Radiograficamente, GONZALEZ et al.* (2006) traçaram uma linha para contornar o espaço interdentário, interligando todos os seus constituintes (contato proximal, superfície coronária, junção cemento-esmalte, superfície radicular supra-óssea e crista óssea alveolar), como observado na Figura 6.5.

* GONZALEZ, M.K.S. et al. Interdental papilla's house: a new concept and a guide for clinicians - part 1. Int J Periodontics Restorative Dent / em processo de publicação. 


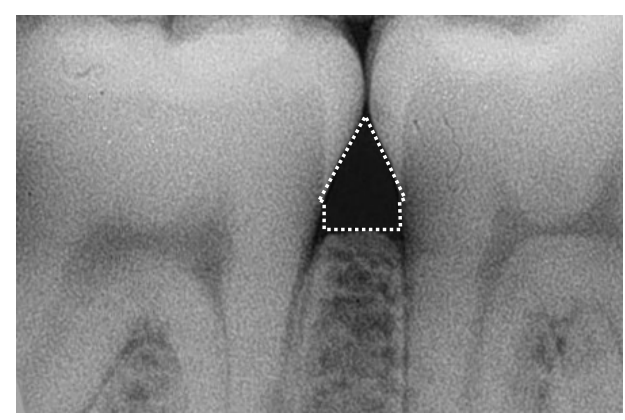

FIGURA 6.5 - Radiograficamente, a delimitação do espaço interdentário assemelha-se a uma "casa" (GONZALEZ et al. ${ }^{*}$ ).

A partir dessa delimitação, GONZALEZ et al. (2006)* estabeleceram o conceito da "Casa da papila" para possibilitar um melhor entendimento dos fatores que modificam o espaço interdentário, e consequentemente, a morfologia da PG. Segundo os autores, o conhecimento das características dos 7 componentes da "casa da papila" (espaço interdentário), que incluem "ápice do telhado" (contato proximal), "contorno dos telhados" (superfície proximal dos dentes), "limite entre telhado e parede" (junção cemento-esmalte), "distância entre paredes laterais" (distância inter-radicular supra-óssea), "base da casa" (nível da crista óssea), "altura da casa" (altura do tecido gengival supra-ósseo) e "limpeza do telhado" (controle de placa bacteriana), permitem também diagnosticar a causa da presença do "buraco negro", bem como, manejar e prever a reconstrução da PG.

No presente estudo, o conceito da "Casa da papila" foi empregado para estabelecer um espaço interdentário adequado para formação da PG durante a fase pós-operatória, considerando-se 9 os componentes da "casa da papila", conforme Tabela 6.3. Cada um dos constituintes do espaço interdentário foi relacionado aos componentes da "casa" e suas características foram analisadas e discutidas de acordo com parâmetros clínicos ou radiográficos descritos por GONZALEZ et al. (2006)*.

* GONZALEZ, M.K.S. et al. Interdental papilla's house: a new concept and a guide for clinicians - part 1. Int J Periodontics Restorative Dent / em processo de publicação. 
TABELA 6.3 - Comparação entre constituintes do espaço interdentário e componentes da "Casa da papila", e seus respectivos parâmetros clínicos ou radiográficos.

\begin{tabular}{|c|c|c|}
\hline Espaço interdentário & "Casa da Papila" & $\begin{array}{l}\text { Parâmetros clínicos ou } \\
\text { radiográficos }\end{array}$ \\
\hline \multirow{2}{*}{$\begin{array}{l}\text { Localização e extensão do } \\
\text { contato proximal }\end{array}$} & "União dos telhados" & $\begin{array}{l}\text { Localização do contato vestibular à } \\
\text { linha da fossa central }\end{array}$ \\
\hline & $\begin{array}{l}\text { "Altura dos telhados" } \\
(2)\end{array}$ & $\begin{array}{l}\text { Localização do contato no terço } \\
\text { incisal ou oclusal }\end{array}$ \\
\hline Contorno dentário proximal & $\begin{array}{l}\text { "Contorno dos telhados" } \\
\text { (3) }\end{array}$ & $\begin{array}{c}\text { Contorno proximal plano e linhas } \\
\text { angulares de transição retas, entre } \\
\text { junção cemento esmalte e contato } \\
\text { proximal }\end{array}$ \\
\hline $\begin{array}{l}\text { Configuração da junção } \\
\text { cemento-esmalte }\end{array}$ & $\begin{array}{l}\text { "Limite entre telhado e } \\
\text { parede" } \\
(4)\end{array}$ & $\begin{array}{c}\text { Biotipo periodontal ou espessura } \\
\text { gengival }\end{array}$ \\
\hline $\begin{array}{l}\text { Distância inter-radicular } \\
\text { supra-óssea }\end{array}$ & $\begin{array}{c}\text { "Distância entre paredes } \\
\text { laterais" } \\
\text { (5) }\end{array}$ & $\begin{array}{l}\text { Distância inter-radicular } \\
\text { supra-óssea }\end{array}$ \\
\hline Localização da crista óssea & $\underset{(6)}{\text { "Base da casa" }}$ & $\begin{array}{l}\text { Distância da junção cemento- } \\
\text { esmalte até crista óssea }\end{array}$ \\
\hline Controle de placa & $\begin{array}{l}\text { "Limpeza dos telhados" } \\
(7)\end{array}$ & Controle de placa \\
\hline $\begin{array}{l}\text { Distância da crista óssea } \\
\text { até contato proximal }\end{array}$ & $\begin{array}{l}\text { "Altura da casa" } \\
(8)\end{array}$ & $\begin{array}{c}\text { Distância da crista óssea até } \\
\text { contato proximal }\end{array}$ \\
\hline Altura da papila & $\begin{array}{l}\text { Altura do tecido } \\
\text { gengival supra-ósseo } \\
\text { (9) }\end{array}$ & $\begin{array}{c}\text { Distância da crista óssea até } \\
\text { vértice da papila }\end{array}$ \\
\hline
\end{tabular}

Como o tratamento protético definitivo foi planejado para ser realizado após 12 meses de avaliação, um "telhado" (contato e contorno dentário proximal) provisório para "casa da papila" foi construído por meio de restaurações ou coroas provisórias. O contorno proximal e linhas angulares de transição ("contorno dos telhados") foram realizados com características planas ${ }^{13,72}$, desde a margem até contato proximal. As margens cervicais foram bem adaptadas para impedir acúmulo de placa ("limpeza dos telhados"). 0 
contato proximal ("união dos telhados"), quando analisado numa vista oclusal, localizou-se vestibular à linha da fossa central e, numa vista vestibular, localizou-se no terço oclusal ("altura do telhado") ${ }^{13}$. A localização provisória do contato proximal mais para oclusal teve como objetivo não interferir na formação completa da PG. Isso resultou num espaço entre o vértice da papila e o "telhado da casa", que clinicamente é denominada de "buraco negro". Na presença desse "buraco", cada paciente foi orientado com relação ao uso de escovas interdentais, para obter adequado controle de placa bacteriana ("limpeza adequada dos telhados") (Tabela 5.3) e prevenir a inflamação gengival durante os períodos de reparação periodontal (Tabela 5.4).

A altura de TGS (medida da crista óssea até o vértice da PG) nos sítios $\mathrm{M}$ e $\mathrm{D}$, descrita na Tabela 5.14, correspondeu respectivamente, à altura da PG mesial (M) e distal (D). Após sutura dos retalhos, a altura da PG reduziu significantemente de $3,48 \mathrm{~mm}$ para $2,43 \mathrm{~mm}$ na $\mathrm{M}$ e de $3,40 \mathrm{~mm}$ para $2,34 \mathrm{~mm}$ na $D$, apesar do cuidado na preservação do tecido gengival proximal. Após RO, as extremidades dos retalhos nas áreas proximais foram excisadas para evitar sobreposição. Esse procedimento eliminou a porção do retalho com maior volume da $\mathrm{PG}$, que associado à sutura que manteve o retalho em contato com o osso subjacente, resultou em diminuição da altura da PG. A formação da PG (reformação da medida pré-cirúrgica de TGS) foi o resultado esperado após cirurgia periodontal, alcançando uma altura final de 3,88mm na $\mathrm{M}$ e $3,84 \mathrm{~mm}$ na D. O aumento médio de coroa clínica aparente obtido ao final do estudo de 0,52mm (sítios M) e 0,74mm (sítios D) (Tabela 5.17), representou um aumento na "altura da casa da papila" (distância da crista óssea até contato proximal), devido a RO que estabeleceu a "base da casa" (nível da crista óssea) para apical (Tabela 5.9 e 5.23). A RO também resultou em alteração na distância inter-radicular supra-óssea ("distância entre paredes laterais") (Tabela 5.10). O aumento médio na distância inter-radicular de 0,37mm (M) e 0,46mm (D) não influenciou significantemente as dimensões laterais da "casa". Neste caso, o restabelecimento da "altura da casa" compatível com a altura da PG (altura de TGS) será alcançado por meio do tratamento protético definitivo, deslocando apicalmente o "telhado" (contato e contorno proximal). Mas caso a RO fosse 
maior, resultando num aumento de todas as dimensões do espaço interdentário, transformando a "casa da papila" em "sobrado", um tratamento multidisciplinar seria necessário para recuperar as dimensões originais da "casa da papila" ou reduzir as dimensões do "sobrado", para melhor acomodação da PG.

A gengiva marginal livre apresenta um contorno côncavo natural que é determinado pelo nível ósseo, e consequentemente, pela junção cementoesmalte (JCE). A configuração da JCE proximal ("limite entre telhado e parede") depende da face, tipo de dente ${ }^{57}$ e biotipo periodontal ${ }^{58}$, e influencia diretamente a morfologia da PG $^{9}$. SEIBERT, LINDHE ${ }^{58}$ (1989) classificaram dois tipos periodontais bem definidos: biotipo espesso e fino. As características relacionadas ao biotipo periodontal fino incluem tecido gengival e ósseo finos, contorno côncavo da MG mais pronunciado, dentes alongados com mínimo contato proximal, configuração da JCE proximal mais convexa para oclusal/incisal e crista óssea proximal mais afilada. Ao contrário, no biotipo espesso, o contorno da JCE proximal apresenta-se menos convexo no sentido vestíbulo-lingual, resultando em uma crista óssea mais plana e um contorno côncavo gengival mais suave, coroas dentárias mais curtas com extensas áreas de contato proximal e tecido gengival e ósseo espessos no sentido vestíbulo-lingual. Neste estudo, a presença de desgastes incisais, alterações na forma dentária com restaurações e coroas protéticas e perdas dentárias dificultaram o emprego dessa classificação, sendo que a análise clínica da JCE foi realizada por meio da espessura gengival. Pelos resultados obtidos, nenhuma correlação significante foi verificada entre formação da PG e a espessura gengival. A configuração proximal da JCE é o único componente da "casa da papila" que não pode ser modificado pela terapia odontológica, mas deve ser utilizado como diagnóstico clínico. A análise do biotipo periodontal e/ou da espessura gengival antes do início de qualquer tratamento, permite ao profissional preservar ou restabelecer características dentárias e periodontais inerentes ao paciente, compreender e prever as reações teciduais adversas da MG (recessão gengival ou hiperplasia gengival) e do osso alveolar (reabsorção óssea), decorrentes do acúmulo de placa ou dos procedimentos odontológicos realizados $^{7,20,58}$. 
A análise desses parâmetros clínicos relacionados à "casa da papila" resultou na construção de uma "casa" provisória favorável à formação da PG (Tabela 6.3). Apesar disso, um fenômeno que tem sido pouco avaliado é o modo como a PG preenche novamente a sua "casa", uma vez removida cirurgicamente.

Na terapia cirúrgica de bolsas periodontais profundas, RAMFJORD, NISSLE $^{50}$ (1974) e RAMFJORD ${ }^{51}$ (1977) relataram formação de uma arquitetura de tecido mole interdentário plana ou côncava após cirurgia de retalho (Widman modificado), especialmente em áreas com crateras ósseas. $\mathrm{A}$ recomendação dos autores para um controle de placa meticuloso nessas áreas resultaria em regeneração do tecido gengival interdentário em poucos meses, com ganho de inserção clínica. Em 1985, RENVERT et al. ${ }^{54}$, documentaram ocorrência de crateras de tecido mole após terapia regenerativa e consideraram o seu desenvolvimento como um aspecto comum ou inevitável após cirurgia de retalho reposicionado em defeitos intra-ósseos.

SHAPIRO $^{59}$ (1985) relatou a realização de uma curetagem periódica em crateras gengivais, decorrentes da gengivite ulcerativa necrosante ocorrida há 6 meses, em 2 pacientes. Controles periódicos a cada 3 meses foram realizados até a regeneração da PG. Nenhuma alteração na cratera gengival foi observada nos 3 primeiros meses após curetagem periódica. Após esse período inicial de latência, um novo tecido gengival, que preencheu o fundo da cratera, foi considerado como resultado de hiperplasia inflamatória. Este tecido apresentou uma textura descrita como pebbly ("pedregosa"), que foi totalmente distinta do tecido gengival normal circunjacente, desaparecendo aos 9 meses. Nesse período, a regeneração máxima da PG foi alcançada, com profundidade de sondagem menor que $3 \mathrm{~mm}$ e ganho no nível de inserção clínica. A aparência das áreas tratadas ao final de 7 anos foi quase uma regeneração da papila com marcante migração coronal do tecido gengival marginal. Algumas $P G$ regeneraram até o nível dos picos $V$ e $L$ da cratera original, deixando uma morfologia gengival interdentária plana; outras $P G$ regeneraram mais coronalmente, resultando numa forma convexa; algumas PG não regeneraram. 
JENKINS; WRAGG; GILMOUR ${ }^{31}$ (1990) realizaram um estudo clínico para monitorar o desenvolvimento e reparo dos defeitos gengivais na PG após curetagem em campo aberto, sem recontorno ósseo, em 21 pacientes com áreas com bolsa periodontal e sangramento. Os retalhos proximais foram bem adaptados e suturados, sendo que 51 áreas foram mantidas com cimento cirúrgico e 49 áreas restantes, sem cimento. Nos períodos de 1, 3 e 6 meses após cirurgia, o contorno gengival proximal foi examinado clinicamente e em modelos de gesso obtidos a partir de moldagens com silicone. Dois tipos de defeitos gengivais foram identificados no controle de 1 mês: 13 áreas com fendas e $30 \mathrm{com}$ crateras. Entre os períodos de 1 e 6 meses, as crateras gengivais mostraram uma maior tendência de reparação do que as fendas. $O$ desenvolvimento de defeitos gengivais não foi relacionado ao uso do cimento cirúrgico ou à presença de defeito ósseo subjacente.

JENKINS; WRAGG; GILMOUR ${ }^{31}$ (1990) e RENVERT et al. ${ }^{54}$ (1985) relacionaram alguns fatores que poderiam, teoricamente, influenciar a resposta reparadora do tecido interdentário após cirurgia de retalho reposicionado, como quantidade de suporte ósseo subjacente, quantidade de espaço criado abaixo do retalho suturado e o grau de proteção da ferida. Ao final do procedimento cirúrgico, a margem do retalho deveria estar suportada por osso saudável, ao invés de defeito ósseo preenchido com coágulo sanguíneo, aumentando o risco de colapso da ferida pós-cirúrgica. SEIBERT, LINDHE $^{58}$ (1989) também relataram que a contração das margens do retalho durante a reparação, após remoção excessiva do tecido conjuntivo da PG, poderia resultar em defeitos gengivais.

No presente trabalho, parâmetros clínicos relacionados à forma, aspecto e contorno foram avaliados para compreender o processo de formação da $P G$, e principalmente, determinar o tempo final de sua formação.

A cratera gengival relatada por JENKINS; WRAGG; GILMOUR ${ }^{31}$ (1990) como depressão visível no tecido interdentário no sentido vestíbulolingual, correspondeu à forma côncava observada neste estudo. Os dados da Tabela 5.21 demonstram que a concavidade na PG M esteve presente em 
$46,2 \%$ e na PG D em 51,7\%, previamente à cirurgia. A presença da forma côncava na $P G$ na fase pré-cirúrgica poderia estar relacionada às alterações nos componentes da "casa da papila", como "telhado" (contato proximal, contorno proximal, adaptação marginal), "limpeza do telhado" (controle de placa) e "parede lateral" (TC invadindo o espaço da distância biológica), causando inflamação gengival. Por meio da cirurgia, foi possível restabelecer a distância biológica e com a confecção de novas restaurações ou coroas provisórias após 2 semanas da cirurgia, foi possível construir uma "casa da papila" provisória favorável à sua formação. No primeiro mês pós-cirúrgico, as porcentagens médias de PG $\mathrm{M}$ e $\mathrm{D}$ com forma côncava aumentaram para $69,2 \%$ e $82,8 \%$, respectivamente. SEIBERT; LINDHE ${ }^{58}$ (1989) mencionaram que a depressão no vértice da PG frequentemente ocorre após incisão que separa a PG em segmento $V$ e L. Apesar dessa incisão ter sido realizada em todas as áreas proximais dos pré-molares, a forma côncava não foi evidente em todas as PG, demonstrando a influência de outros fatores relacionados aos procedimentos cirúrgicos (incisão, elevação dos retalhos, ressecção óssea e sutura), morfologia gengival e óssea, dificuldade e habilidade técnica do profissional na manipulação dos retalhos. Por isso, quando presente na fase pós-cirúrgica imediata, a forma côncava pode ser considerada como um dos estágios iniciais de formação da PG.

O comportamento das $P G$ no presente trabalho foi similar àquele relatado por SHAPIRO ${ }^{59}$ (1985), demonstrando que algumas PG com forma côncava adquiriram uma forma plana, outras forma convexa e algumas não modificaram a sua forma inicial. A porcentagem de PG com forma côncava reduziu significantemente para 4,2\% (M) e 18,5\% (D), após 12 meses (Tabela 5.21). Esses achados clínicos estão de acordo com estudo de JENKINS; WRAGG; GILMOUR ${ }^{31}$ (1990), que mostraram tendência de reparação das crateras gengivais, sem interferir no restabelecimento da saúde gengival (Tabela 5.4). A presença da forma côncava aos 12 meses também pode estar relacionada ao contato proximal, pela formação da área do col.

Apesar do aspecto stippling ser uma característica clínica que nem sempre está presente na gengiva inserida saudável ${ }^{10,26}$, procurou-se avaliar 0 
seu comportamento durante o processo de reparo. Na Tabela 5.21, a porcentagem média pré-cirúrgica de PG com aspecto stippling foi de 19,2\% para $\mathrm{M}$ e 17,2\% para D. Após 1 mês da cirurgia, esse aspecto foi evidente em $11,5 \%$ das PG $\mathrm{M}$ e em 6,9\% das PG D, demonstrando que procedimentos cirúrgicos não alteraram essa característica tecidual. Durante a reparação, houve um aumento gradual da presença do aspecto stippling nas PG, alcançando uma porcentagem de $87,5 \%$ (M) e 74,1\% (D), aos 12 meses. $A$ partir desse aumento significante, pode-se sugerir que as PG restabeleceram as suas características saudáveis após maturação do tecido conjuntivo gengival ou que refletiram a localização do contato proximal, que foi posicionado mais coronalmente (com aumento da "altura do telhado"). Segundo HASSELL $^{26}$ (1993) quando dois dentes adjacentes não apresentam contato proximal ou quando da perda de um dente, a gengiva inserida está presente em toda a extensão vestíbulo-lingual, sem área do $\mathrm{col}^{26}$. Na presença da área do col, o epitélio que cobre o tecido conjuntivo gengival não é ceratinizado ${ }^{26}$ e não apresenta aspecto stippling.

A PG clinicamente normal e saudável revela um formato triangular, com contorno uniforme desde a sua base até o seu vértice, numa vista vestibular. Contudo, 51,9\% das PG M e 75,9\% das PG D apresentaram um contorno vestibular com "dobra" na sua porção mais coronal, na fase précirúrgica (Tabela 5.21). Quando analisada no sentido ocluso-gengival, este sinal clínico na PG representa uma marca horizontal bem definida e localizada apical ao seu vértice (Figura 4.7-A e Figura 5.2). Uma moldagem da PG com este contorno foi realizada para obter um modelo de gesso, de forma que a PG pudesse ser analisada no sentido vestíbulo-lingual. Como observado na Figura 4.7-B, a "dobra" correspondeu a um achatamento na porção vestibular da PG. A sua presença na fase pré-cirúrgica poderia estar relacionada aos sítios com TC invadindo o espaço da distância biológica, com contorno proximal inadequado e com desadaptação marginal das coroas provisórias. Após 1 mês da cirurgia, todas as PG M e D apresentaram esse contorno irregular. Isso representa que a sua formação pode ser um fenômeno esperado após cirurgia de aumento de coroa, ao contrário da presença da forma côncava e ausência 
do aspecto stippling. Após 12 meses, houve redução significante na porcentagem de PG com "dobra" para 25,0\% (M) e 40,7\% (D). Fatores, como aumento da rugosidade superficial das restaurações/coroas provisórias após 12 meses, permitindo acúmulo de placa ("limpeza do telhado"); subcontorno ("contorno do telhado"); localização do contato mais para oclusal ("altura do telhado") poderiam contribuir na presença da "dobra", bem como, a formação incompleta da PG (reformação da medida de TGS).

Nenhum relato ou estudo clínico tem sido encontrado na literatura sobre a presença da "dobra", ou qualquer alteração morfológica na PG após cirurgia de aumento de coroa. A sua presença deve ser analisada cuidadosamente, buscando avaliar fatores e condições que podem influenciar o seu aparecimento, uma vez que PG normal e saudável apresenta-se com contorno uniforme.

Diferente de se estabelecer medidas médias fixas da "altura da casa" (distância da crista óssea até contato proximal) para prever a formação da PG, o conceito da "Casa da papila" tem considerado a variabilidade de cada sítio proximal em diferentes grupos dentários ("casa individual" para cada papila), permitindo avaliar, diagnosticar e prever a formação da PG, por meio de parâmetros clínicos e radiográficos.

Neste estudo, um monitoramento clínico da alteração da MG foi realizado sem intenção de determinar seqüência de eventos histológicos, como migração do epitélio juncional, formação de cemento com inserção de fibras colágenas e maturação das fibras colágenas. Contudo, as medidas clínicas selecionadas (profundidade de sondagem inicial, controle de placa bacteriana e do sangramento gengival) confirmaram que o evento clínico analisado, ou seja, a alteração da MG não foi influenciada pela inflamação tecidual decorrente do acúmulo de placa bacteriana. Os resultados obtidos após 12 meses demonstraram que a $\mathrm{MG}$ do retalho reposicionado e suturado coronal à crista óssea não interferiu na profundidade de sondagem e no nível da junção mucogengival, quando comparada à fase pré-cirúrgica. A migração da MG para apical ou coronal a partir da margem do retalho suturado, representou uma 
tendência dos TGS de retornar à sua medida original. Dessa forma, um método clínico hipotético PEM foi sugerido para ser utilizado como guia para que o profissional possa monitorar o comportamento da MG durante processo de reparo, determinar e prever a estabilidade da MG, e consequentemente, a formação da $P G$.

A formação da PG após cirurgia de aumento de coroa pode ser compreendida clinicamente como migração coronal da MG e restabelecimento da arquitetura côncava marginal nas faces livres, microscopicamente como restabelecimento das medidas de inserção de tecido conjuntivo nas "paredes laterais da casa" e do epitélio juncional e sulcular no "telhado da casa" e radiograficamente, como adaptação da margem cervical das restaurações, contorno proximal adequado e localização do contato proximal em relação à crista óssea, construindo um novo "telhado" mais apicalmente. 


\section{1 - Avaliação radiográfica}

A distância radiográfica entre crista óssea e a JCE corresponde à real distância anatômica quando o feixe de raios-x for direcionado perpendicular ao osso e quando o filme for posicionado paralelamente ao eixo longitudinal do dente e osso adjacente ${ }^{27}$. Nas tomadas radiográficas interproximais é possível posicionar o filme mais corretamente e o feixe de raios- $x$ mais próximo de $90^{\circ}$ do que as tomadas periapicais. Por isso, neste estudo, a avaliação radiográfica longitudinal foi realizada por meio da técnica radiográfica interproximal padronizada, para obter uma imagem anatomicamente correta da posição do osso alveolar em relação ao término cervical (ponto de referência fixo).

Alguns fatores externos poderiam interferir na qualidade das imagens obtidas, como a não padronização das tomadas radiográficas, do processamento radiográfico, da digitalização das radiografias convencionais e do erro de medida ${ }^{56}$. A metodologia deste trabalho minimizou ao máximo essas interferências. Para isso, a posição da fonte de raios-x, filme, objeto foi mantida durante todas as radiografias, as radiografias foram fotografas em conjunto, e um mesmo examinador repetiu todas as medidas em diferentes intervalos de tempo.

A avaliação microscópica ainda representa um método ideal de avaliação do reparo ósseo. WILDERMAN et al. ${ }^{73}$ (1970) relataram o reparo dos tecidos periodontais em humanos após retalho total reposicionado e ressecção óssea na face vestibular dos dentes. Inicialmente, um coágulo sanguíneo foi encontrado entre retalho suturado e superfície óssea/dentária. Posteriormente, esse coágulo foi invadido por um tecido conjuntivo jovem composto por novos capilares, fibroblastos e células mesenquimais que proliferaram do tecido conjuntivo do retalho e do ligamento periodontal. Necrose óssea foi observada no osso imediatamente abaixo da superfície óssea reduzida. Após 1 semana, a reabsorção óssea ocorreu na superfície periodontal nos casos de cortical óssea vestibular fina, ao contrário da cortical óssea espessa, onde a reabsorção 
iniciou na superfície óssea voltada para espaços medulares e sistemas de Harvers. A reabsorção óssea na superfície periosteal foi mais demorada, ocorrendo após 2 e 3 semanas. A atividade osteoblástica na crista óssea e superfície periosteal (osso imaturo) alcançou seu pico máximo após 3 e 4 semanas. A partir desse período, a quantidade de formação óssea foi diminuindo, sendo mínima após 6 meses. A substituição do osso imaturo por um tipo intermediário foi observado após 6 meses e por osso maduro, após 18 meses da cirurgia. Nos casos de estrutura óssea com muitos espaços medulares, o reparo ósseo aproximou-se da completa restauração anatômica do osso pós-cirúrgico. Evidências microscópicas indicaram mais perda óssea e menos reparo ósseo em osso alveolar fino e o contrário foi verdadeiro para osso espesso. Novos feixes de fibras colágenas formadas durante o processo de reparo foram embebidas no tecido osteóide na superfície óssea periosteal em alguns sítios após 2 meses. Um novo periósteo estava presente em áreas isoladas sobre a superfície óssea reduzida a partir do $3^{\circ}$ mês, e até $6^{\circ}$ mês, um periósteo definitivo foi evidente sobre toda a superfície óssea periosteal, como aquele observado nos sítios não operados.

Todos esses eventos histológicos não são reproduzidos na radiografia, uma vez que a avaliação radiográfica da alteração óssea (2 dimensões) não reproduz a configuração topográfica do osso alveolar (3 dimensões) ao redor do dente e é necessário que 30 a $60 \%$ do conteúdo mineral do osso tenha sido perdido para visualizar uma alteração na imagem radiográfica ${ }^{53}$. Dessa forma, este estudo teve como objetivo obter informações da relação proximal entre TC e crista óssea e da presença da lâmina dura e comparar radiografias iniciais e subseqüentes para avaliar possíveis alterações ósseas e determinar o período de tempo mínimo para que a imagem da lâmina dura intacta pudesse ser detectada radiograficamente.

A presença de uma lâmina dura intacta foi observada em um sítio mesial e distal após 3 meses da cirurgia (Tabela 5.22). No período de 6 meses, $60,9 \%$ e $66,7 \%$ das crista ósseas M e D, respectivamente, apresentaram lâmina dura, atingindo $100 \%$ dos sítios aos 12 meses (Figura 5.3). A repetição 
da avaliação radiográfica da lâmina dura não demonstrou diferença em relação à primeira interpretação, realizada pelo mesmo examinador após 2 meses.

A lâmina dura, uma densa linha radiopaca, representa o osso compacto com poucos e/ou menores espaços medulares que recobre a crista. A sua aparência é determinada pela forma e posição da raiz em relação ao feixe de raios- $x$, bem como, pela integridade do osso que recobre a crista óssea $^{27}$. REED; POLSON ${ }^{52}$ (1984) também relataram que a imagem radiográfica da lâmina dura depende da angulação do feixe, pois a sua radiopacidade demonstra que o feixe de raios-x atravessou tangente pela cortical óssea. E pelos resultados obtidos após 12 meses, pode-se sugerir que o feixe de raios-x aproximou-se dessa direção.

Dos estudos encontrados na literatura, somente DIBART et al. ${ }^{19}$ (2003) realizaram uma análise radiográfica após cirurgia de aumento de coroa com finalidade restauradora. Na avaliação radiográfica retrospectiva de 5 anos após cirurgia, os autores observaram lesão de furca em dentes molares inferiores, quando a distância entre a entrada da furca e a margem da coroa protética foi $<4 \mathrm{~mm}$. Nenhuma análise foi realizada no nível ósseo proximal.

A análise radiográfica neste estudo foi prospectiva e padronizada e as medidas lineares entre TC e crista óssea foram de fácil obtenção com a utilização do programa Image $J^{\circledR}$. A ferramenta de seleção de área deste programa permitiu a manutenção do tamanho e forma da área selecionada totalmente padronizada, oferecendo maior confiabilidade ao método de medida. $\mathrm{Na}$ imagem radiográfica pré-cirúrgica, os valores médios obtidos para essas medidas lineares foram de $2,10 \mathrm{~mm}$ e $1,54 \mathrm{~mm}$, respectivamente, para cristas ósseas $M$ e $D$ aos dentes pré-molares (Tabela 5.23). Com RO, as medidas lineares aumentaram significantemente, localizando as cristas ósseas, em média, 3,28mm (M) e 2,81 mm (D) distantes do TC. A quantidade média de RO foi de $1,17 \mathrm{~mm}$ (M) e 1,26mm (D) (Tabela 5.24). Durante todo período de reparo, os níveis das cristas ósseas $M$ e $D$ apresentaram alterações para apical sem diferença estatisticamente significante. Como observado nos eventos microscópicos, osso alveolar espesso com muitos espaços medulares 
apresenta mínimas alterações dimensionais ao final do processo de reparo quando comparado à dimensão pós-cirúrgica imediata.

LANNING et al. ${ }^{35}$ (2003) obtiveram medidas do nível ósseo aos 3 e 6 meses após cirurgia, por meio de sondagem transgengival, após anestesia da área. Apesar dos autores terem observado uma alteração média clínica significante no nível ósseo de $0,77 \mathrm{~mm}$ para apical, entre a fase pós-osteotomia e 3 meses, essa medida representou a média dos 4 sítios (mésio-vestibular, mésio-lingual, disto-bucal e disto-lingual) ao redor de cada dente tratado. A representação média de todos os sítios examinados não permite uma análise comparativa com os achados radiográficos nas cristas ósseas $M$ e $D$ descritos na Tabela 5.24. Além disso, pode-se sugerir que a maior alteração no nível ósseo tenha ocorrido na crista óssea fina, encontrada frequentemente nas faces livres, que são propensas à reabsorção óssea.

Os resultados da avaliação radiográfica demonstraram que houve estabilização do nível da crista óssea ("base da casa da papila") ao final do estudo. Como a MG nos sítios M e D mostrou tendência à estabilização após 12 meses, pode-se sugerir que fatores relacionados ao contato ou contorno dentário proximal ("telhado da casa"), como citados anteriormente, poderiam estar influenciando na formação completa da PG, ou também, que uma vez estabelecido a "base da casa", a PG requer um tempo maior para reformar toda a sua dimensão original. 

CONCLUSÕES 



\section{CONCLUSÕES}

Baseando-se na proposição e na metodologia empregada no presente estudo, pode-se concluir que:

1a) Nos sítios $V$ e $L$, as margens dos retalhos suturadas coronal à crista óssea, próximo ou na medida pré-cirúrgica do tecido gengival supra-ósseo, alcançaram estabilização clínica da margem gengival aos 4 meses;

1b) Nos sítios proximais, as margens dos retalhos suturadas coronal à crista óssea, aproximadamente $1 \mathrm{~mm}$ inferior à medida précirúrgica do tecido gengival supra-ósseo, apresentaram migração coronal da margem gengival com tendência à estabilização após 12 meses. A formação da papila gengival também apresentou alterações morfológicas no sentido vestíbulo-lingual;

1c) A técnica do retalho reposicionado e suturado coronal à crista óssea (próximo ou na medida pré-cirúrgica do tecido gengival supraósseo) pode ser utilizada para alcançar mais rapidamente a estabilidade da margem gengival, permitindo reiniciar os procedimentos protéticos; 
2) A análise radiográfica das cristas alveolares proximais detectou alterações insignificantes no nível ósseo durante período pósoperatório, demonstrando que a crista alveolar proximal pósosteotomia pode ser utilizada como referência para localizar o vértice da papila gengival, baseando-se na reformação do tecido gengival supra-ósseo;

3) A medida pré-cirúrgica do tecido gengival supra-ósseo obtida individualmente para cada sítio ao redor do dente a ser tratado pode ser sugerida como parâmetro clínico, utilizando o término cervical como ponto de referência, para:

- determinar a quantidade de ressecção óssea a ser realizada;

- monitorar a reparação da margem gengival;

- determinar a estabilidade da margem gengival;

- prever a sua futura posição. 
ANEXOS 



\section{ANEXOS}

\section{ANEXO 1}

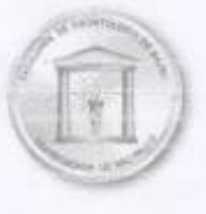

\section{Universidade de São Paulo \\ Faculdade de Odontologia de Bauru}

Al. Dr. Octávio Pinheiro Brisolla, 9-75 - Bauru-SP-CEP $17012-901$ - C.P. 73

PABX (0XX14)3235-8000-FAX (0XX14)3223-4679

Comile de Ética em Pesquisa

Processo $n^{\circ} 36 / 2004$

Bauru, 05 de abril de 2004.

Senhor Professor,

O projeto de pesquisa encaminhado a este Comitê de Ética em Pesquisa em Seres Humanos, denominado "Avaliaçâo longitudinal do processo de reparo dos tecidos periodontias marginais após procedimento cirúrgico de recuperaçăo de distîncias biológicas", de autoria de Marly Kimie Sonohara, que será desenvolvido sob sua orientação, foi enviado ao relator para avaliação.

Na reuniảo de 31 de marce de $\mathbf{2 0 0 4}$ o parecer do relator, aprovando o projeto, foi aceito pelo Comitê, considerando que nào existem infrações éticas pendentes.

Informamos que após o envio do trabalho concluido, este Comitê enviará o parecer final, que será utilizado para publicação do trabalho.

Atenciosamente,

Prof Dr. Arsento Sarestopes

Vice-Coordenadgr

Ilm ${ }^{\circ}$ Sr. Prof. Dr. Sebastião Luiz Aguiar Greghi

DD. Docente do Departamento de Prótese (Disciplina de Periodontia) 

REFERÊNCIAS BIBLIOGRÁFICAS 



\section{REFERÊNCIAS BIBLIOGRÁFICAS*}

1. AFSHAR-MOHAJER, K.; STAHL, S.S. The remodeling of human gingival tissues following gingivectomy. J Periodontol, v. 48, n. 3, p. 136-139, Mar. 1977.

2. AINAMO, J.; BAY, I. Problems and proposals for recording gingivitis and plaque. Int Dent J, v. 25, n. 4, p. 229-235, 1975.

3. ÁVILA, M.A.G. Análise das distorções da imagem radiográfica em diferentes aparelhos panorâmicos. 1996. 124f. Dissertação (Mestrado em Odontologia) - Faculdade de Odontologia de Bauru, Universidade de São Paulo, Bauru, 1996.

4. BADERSTEN, A.; NILVEUS, R.; EGELBERG, J. Reproducibility of probing attachment level measurements. J Periodontol, v. 11, p. 475-485, 1984.

5. BASS, C.C. apud LINDHE, J.; NYMAN, S. Alterations of the position of the marginal soft tissue following periodontal surgery. J Clin Periodontol, v. 7, p. 525-530, 1980.

6. BECKER, W.; OCHSENBEIN, C.; BECKER, B.E. Crown lengthening: the periodontal-restorative connection. Compend Contin Educ Dent, v. 19, p. 239-246, 1998.

* Normas recomendadas para uso no âmbito da Faculdade de Odontologia de Bauru - USP, com base na Associação Brasileira de Normas Técnicas - ABNT NBR 6023/ ago. 2002 
7. BECKER, W. et al. Alveolar bone anatomic profiles as measured from dry skulls. Clinical ramification. J Clin Periodontol, v. 24, n. 10, p. 727-731, 1997.

8. BELL, L.A. et al. The presence of "creeping attachment" in human gingival. $\mathbf{J}$ Periodontol , v. 49, n. 10, p. 513-517, Oct. 1978.

9. BENSIMON, G.C. Surgical crown-lengthening procedure to enhance esthetics. Int J Periodontics Restorative Dent, v. 19, n. 4, p. 333-341, 1999.

10.BERGSTRÖM, J. The topography of papillary gingiva in thealth and early gingivitis. J Clin Periodontol, v. 11, p. 423-431, 1984.

11.BLOCK, P.L. Restorative margins and periodontal healthy: a nwelood at an old perspective. J Prosthet Dent, v. 57, p. 683-689, June, 1987.

12.BRÄGGER, U.; LAUCHENAUER, K.; LANG, N.P. Surgical lengthening of the clinical crown. J Clin Periodontol, v. 19, n. 1, p. 58-63, Jan.1992.

13. BURCH, J.G. Ten rules for developing crown contours in restorations. Dent Clin North Am, v. 15, p. 611-618, 1971.

14. CLAFFEY, N.; SHANLEY, D. Relationship of gingival thickness and bleeding to loss of probing attachment in shallow sites following nonsurgical periodontal therapy. J Clin Periodontol, v. 13, n. 7, p. 654-657, Aug. 1986.

15. CLARK, D.C. et al. Reliability of attachment level measurements using the cemento-enamel junction and a plastic stent. J Periodontol, v. 58, n. 2, p. 115-118, Feb. 1987.

16. COESTA, P.T.G. A extensão das distâncias biológicas do periodonto marginal: comparações clínicas e radiográficas. 2003. 93f. Dissertação (Mestrado em Odontologia) - Faculdade de Odontologia de Bauru, Universidade de São Paulo, Bauru, 2003. 
17. COHEN, D.W. apud INGBER, F.J.S.; ROSE, L.F.; COSLET, J.G. The "biologic width" - a concept in periodontics and restorative dentistry. Alpha Omega, v. 70, p. 62-65, 1977.

18.DEAS, D.E. et al. Osseous surgery for crown lengthening: a 6-month clinical study. J Periodontol, v. 75, n. 9, p. 1288-1294, Sept. 2004.

19.DIBART, S. et al. Crown lengthening in mandibular molars: a 5-year retrospective radiographic analysis. J Periodontol, v. 74, n. 6, p. 815821, June, 2003.

20.EGER, T.; MÜLLER, H.P.; HEINECKE, A. Ultrasonic determination of gingival thickness. Subject variation and influence of tooth type and clinical features. J Clin Periodontol, v. 23, p. 839-845, 1996.

21.FRIEDMAN, N. Mucogengival surgery: the apically repositioned flap. $\mathbf{J}$ Periodontol, v. 33, p. 328-340, 1962.

22. FUGAZZOTTO, P.A.; PARMA-BENFENATI, S. Preprosthetic periodontal considerations. Crown length and biologic width. Quintessence Int, v. 15, n. 12, p. 1247-1256, Dec. 1984.

23. GARGIULO, A.W.; WENTZ, F.M.; ORBAN, B. Dimensions and relations of the dentogingival junction in humans. J Periodontol, v. 32, p. 261-267, 1961.

24. GOLDMAN, H.M. et al. Mucogingival surgery. In: Periodontal therapy. $3^{\text {rd }}$. ed. Saint Louis: Mosby, 1964. cap. 18, p. 556-560.

25. GÜNAY, H. et al. Placement of the preparation line and periodontal health a prospective 2-year clinical study. Int J Periodontics Restorative Dent, v. 20, n. 2, p. 173-181, 2000.

26. HASSELL, T.H. Tissues and cells of the periodontium. Periodontol 2000, v. 3, p. 9-38, Oct. 1993. 
27. HAUSMANN, E. A contemporary perspective on techniques for the clinical assessment of alveolar bone. J Periodontol, v. 61, n. 3, p. 149-156, Mar. 1990.

28. HERRERO, F. et al. Clinical comparison of desired versus actual amount of surgical crown lengthening. J Periodontol, v. 66, n. 7, p. 568-571, July, 1995.

29. INGBER, F.J.S.; ROSE, L.F.; COSLET, J.G. The "biologic width" - a concept in periodontics and restorative dentistry. Alpha Omega, v. 70, p. 62-65, 1977.

30. ISIDOR, F.; KARRING, T.; ATTSTROM, R. Reproducibility of pocket depth and attachment level measurements when using a flexible splint. J Clin Periodontol, v. 11, p. 662-668, 1984.

31. JENKINS, W.M.M.; WRAGG, P.F.; GILMOUR, W.H. Formation of interdental soft tissue defects after surgical treatment of periodontitis. J Periodontol, v. 61 , n. 9, p. 564-570, Sept. 1990.

32. KOIS, J.C. Altering gingival levels: the restorative connection. Part I: biologic variables. J Esthet Dent, v. 6, n. 1, p. 3-9, 1994.

33. KOIS, J.C.; VAKAY, R.T. Clinical technique in prosthodontics - relationship of the periodontium to impression procedures. Compend Contin Educ Dent, v. 21, n. 8, p. 684-692, Aug. 2000.

34.LANG, N.K.; LÖE, H. The relationship between the width of keratinized gingival and gingival health. J Periodontol, v. 43, n. 10, p. 623-627, Oct. 1972.

35. LANNING, S.K. et al. Surgical crown lengthening: evaluation of the biological width. J Periodontol, v. 74, n. 4, p. 468-474, Apr. 2003.

36. LINDHE, J.; NYMAN, S. Alterations of the position of the marginal soft tissue following periodontal surgery. J Clin Periodontol, v. 7, p. 525-530, 1980. 
37. LÖE, H.; SILNESS, J. Periodontal disease in pregnancy (I). Prevalence and severity. Acta Odontol Scand, v. 21, p. 533-551, 1963.

38. LUNDERGAN, W.; HUGHES JR, W.R. Crown lengthening: a surgical flap approach. Compend Contin Educ Dent, v. 17, n. 9, p. 833-844, Sept. 1996.

39. MAYNARD, J.G.; WILSON, R.D.K. Physiologic dimensions of the periodontium significant to the restorative dentist. J Periodontol, v. 50, n. 4, p. 170-174, Apr. 1979.

40. MENDONÇA, J.A.G. Avaliação e análise das distâncias biológicas do periodonto mediante nova metodologia. 2001. 106f. Tese (Doutorado em Odontologia) - Faculdade de Odontologia de Bauru, Universidade de São Paulo, Bauru, 2001.

41. MÜLLER, H.P. et al. Thickness of masticatory mucosa. J Clin Periodontol, v. 27, p. $431-436,2000$.

42. NEVINS, M.; SKUROW, H.M. The intracrevicular restorative margin, the biological width, and maintenance of the gingival margin. Int $\mathbf{J}$ Periodontics Restorative Dent, v. 4, n. 3, p. 30-49, 1984.

43. OAKLEY, E. et al. Formations of the biologic width following crown lengthening in nonhuman primates. Int $\mathbf{J}$ Periodontics Restorative Dent, v. 19, n. 6, p. 529-541, 1999.

44. OLSSON, M.; LINDHE, J. MARINELLO, C.P. On the relationship between crown form and clinical features of the gingiva in adolescents. J Clin Periodontol, v. 20, n. 8, p. 570-577, Sept. 1993.

45. PADBURY JR., A.; EBER, R.; WANG, H-L. Interactions between the gingiva and the margin of restorations. J Clin Periodontol, v. 30 , n. 5 , p. 379385, May, 2003.

46.PALOMO, F.; KOPCZYK, R.A. Rationale and methods for crown lengthening. J Am Dent Assoc, v. 96, p. 257-260, Feb. 1978. 
47.PARMA-BENFENATI, S.; FUGAZZOTTO, P.A.; RUBEN, M.P. The effect of restorative margins on the postsurgical development and nature of the periodontium. Part I. Int J Periodontics Restorative Dent, v. 5, n. 6, p. 31-51, 1985.

48. PEREZ, F. Distâncias biológicas: influência da distância do ponto de contato interproximal até a crista óssea e da distância das faces interproximais de dentes adjacentes sobre a presença ou ausência da papila gengival interproximal. 2003. 102f. Dissertação (Mestrado em Odontologia) - Faculdade de Odontologia de Araraquara, Universidade Estadual Paulista, Araraquara, 2003.

49.PONTORIERO, R.; CARNEVALE, G. Surgical crown lengthening: a 12month clinical wound healing study. J Periodontol, v. 72, n. 7, p. 841848, July, 2001.

50.RAMFJORD, S.P.; NISSLE, R.R. The modified widman flap. J Periodontol, v. 45, n. 8, p. 601-607, Oct. 1974.

51. RAMFJORD, S.P. Present status of the modified widman flap procedure. $\mathbf{J}$ Periodontol, v. 48, n. 9, p. 558-565, Sept. 1977.

52. REED, B.E.; POLSON, A.M. Relationships between bitewing and periapical radiographs in assessing crestal alveolar bone levels. J Periodontol, v. 55, n. 1, p. 22-27, Jan. 1984.

53. REEDY, M.S. Radiographic methods in the evaluation of periodontal therapy. J Periodontol, v. 63, n. 12, p. 1078-1084, Dec. 1992.

54. RENVERT, S. et al. Healing after treatment of periodontal intraosseous defects. III. Effect of osseous grafting and citric acid conditioning. J Clin Periodontol, v. 12, p. 441-455, 1985.

55.ROSENBERG, E.S.; GARBER, D.A.; EVIAN, C.I. Tooth lengthening procedures. Compend Contin Educ Dent, v. 1, p. 161-172, 1980. 
56. SCHMITD, L.B. Avaliação radiográfica da reabsorção óssea periodontal por meio de valor de pixel e comparação com análise histopatológica. 2005. 98f. Dissertação (Mestrado em Odontologia) Faculdade de Odontologia de Bauru, Universidade de São Paulo, Bauru, 2005.

57.SEIBERT, J.S. Surgical management of osseous defects. In: GOLDMAN, H.M.; COHEN, D.W. Periodontal therapy, $5^{\text {th }}$. ed. St Louis: Mosby, 1973. cap. 28 , p. $758-828$.

58. SEIBERT, J.; LINDHE, J. Esthetics and periodontal therapy. In: LINDHE, J. Textbook of clinical periodontology. $2^{\text {nd }}$. ed. Copenhagen: Munksgaard, 1989. cap 19, p. 477-514.

59. SHAPIRO, A. Regeneration of interdental papillae using periodic curettage.

Int J Periodontics Restorative Dent, v. 5, p. 27-33, 1985.

60.SILNESS, J.; LÖE, H. Periodontal disease in pregnancy (II). Correlation between oral hygiene and periodontal condition. Acta Odontol Scand, v. 22, p. 747-759, 1964.

61.SMUKLER, H.; CHAIBI, M. Periodontal and dental considerations in clinical crown extension: a rational basis for treatment. Int J Periodontics Restorative Dent, v. 17, n. 5, p. 465-477, 1997.

62. TABA JÚNIOR, M. Monitoração da progressão da doença periodontal através de imagens radiográficas digitalizadas. 1995. $131 \mathrm{f}$. Dissertação (Mestrado em Odontologia) - Faculdade de Odontologia de Bauru, Universidade de São Paulo, Bauru, 1995.

63. TAKEI, H.H. The interdental space. Dent Clin North Am, v. 24, n. 2, p. 169176, Apr. 1980.

64. TAL, $H$. et al. Periodontal response to long-term abuse of the gingival attachment by supracrestal amalgam restoration. J Clin Periodontol, v. 16, n. 10, p. 654-689, 1989. 
65.TARNOW, D.P.; MAGNER, A.W.; FLETCHER, P. The effect of the distance from the contact point to the crest of bone on the presence or absence of the interproximal dental papilla. J Periodontol, v. 63, p. 995-996, 1992.

66. TARNOW, D. et al. Human gingival attachment responses to subgingival crown placement. Margin remodeling. J Clin Periodontol, v. 13, p. 563$569,1986$.

67. VAN DER VELDEN, U. Regeneration of the interdental soft tissues following denudation procedures. J Clin Periodontol, v. 9, n. 6, p. 455-459, Nov. 1982.

68. VIEIRA, S.; HOSSNE, W.S. Experimentação com seres humanos. 2. ed. São Paulo: Moderna, 1987. p. 137-140.

69.WAGENBERG, B.D. Surgical tooth lengthening: biologic variables and esthetic concerns. J Esthet Dent, v. 10, n. 1, p. 30-36, 1998.

70.WAGENBERG, B.D.; ESKOW, R.N.; LANGER, B. Exposing adequate tooth structure for restorative dentistry. Int J Periodontics Restorative Dent, v. 9 , n. 5, p. 323-331, 1989.

71.WENNSTRÖM, J. et al. Periodontal surgery: objectives, indications and techniques for periodontal pockets. In: LINDHE, J. Textbook of clinical periodontology. $2^{\text {nd }}$. ed. Copenhagen: Munksgaard, 1989. cap. 16, p. 386-421.

72. WHEELER, R.C. A textbook of dental anatomy and physiology. $4^{\text {th }}$. ed. Philadelphia: WB Saunders Company, 1965. cap. 5, p. 95-123.

73.WILDERMAN et al. Histogenesis of repair following osseous surgery. $\mathbf{J}$ Periodontol, v. 41, p. 551-565, 1970.

74. WISE, M.D. Stability of gingival crest after surgery and before anterior crown placement. J Prosthet Dent, v. 53, n. 1, p. 20-23, Jan. 1985. 
ABSTRACT 



\section{ABSTRACT}

The aim of this study was to clinically and radiographically investigate the repair of marginal periodontal tissues in 30 premolars without periodontal disease and with surgical indication for crown lengthening for restorative purposes. The surgical technique comprised total flap, osteotomy/osteoplasty to expose at least $3 \mathrm{~mm}$ of healthy tooth structure, and flap margin repositioning and suturing coronal to the bone crest and apical to the restorative margin. Clinical evaluation comprised measurements of gingival margin (GM), relative attachment level (RAL), mucogingival junction (MGJ), gingival thickness and gingival papilla; the presence of dental plaque (DP) and gingival bleeding (GB) was assessed before surgery and re-assessed at 1, 2, 3, 4, 5, 6 and 12 months postoperatively. An occlusal plate with fixed reference points was used to standardize the position of the periodontal probe at the adjacent distal, mesial, buccal $(B)$, lingual $(L)$, distal and adjacent mesial sites. Bite-wing radiographs with individual film holders were standardized and obtained before and after bone surgery and at 2, 3, 6 and 12 months. The clinical results revealed the following: 1) significant reduction in DP and GB at 12 months, except for $L$ sites; 2) no significant alteration in RAL and MGJ during the repair period; 3 ) greater coronal migration of the GM when the flap margin was closer to the bone crest after suture, for reformation of the dimension of the supracrestal gingival tissue (SGT); 4) no correlation between gingival thickness and the amount of migration of the $\mathrm{GM} ; 5$ ) stabilization of the $\mathrm{GM}$ at the $B$ and $L$ sites after the fourth month; 6) significant coronal migration of the proximal GM with tendency to stabilization after 12 months, and 7) morphological alterations of the interdental gingival tissue during formation of the gingival papilla. Radiographically, the lamina dura was intact in all bone crests at 12 months, with no significant alteration in the bone level during the repair period. It was concluded that an earlier marginal tissue stability was achieved when the post-suturing flap margin was placed at, or closer to the presurgical dimension of the SGT. Therefore, it suggests that presurgical dimension of the SGT can be used as a clinical parameter to estimate the amount of osseous resection required, monitor the changes of the $\mathrm{GM}$, and establish and predict the future stable position of the GM, following crown lengthening surgery. 